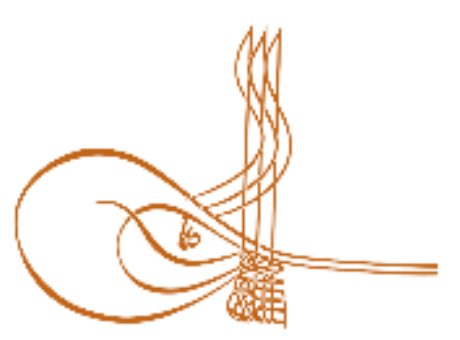

www.turkishstudies.net/turkishstudies
Turkish Studies

eISSN: $1308-2140$

Research Article / Araştırma Makalesi

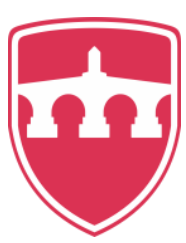

INTERNATIONAL

BALKAN

UNIVERSITY

Sponsored by IBU

\title{
Van Hüsrev Paşa Külliyesi Camii Koruma ve Onarım Çalışmaları
}

The Preservation and Renovation Works of Van Hüsrev Pasha Mosque

\author{
Şahabettin Öztürk ${ }^{*}$
}

\begin{abstract}
Hüsrev Paşa Social Complex which is located in the Old City of Van, had been built by Van Beylerbeyi (Van's Governor) Köse Hüsrev Mehmed Paşa, one of the viziers of Suleiman the Magnificent, between the years of 1567-68. The complex that is a work of Sinan consists of mosque, madrasa, shrine, caravansarai, double hammam, soup kitchen, primary school, lecturer's and guests' houses sections. The mosque that is called "Hüsreviye" and "Kurşunlu" forms the focal point of the complex. The mosque's center is square layouted and covered with a sole dome which subside squinches. A door placed in the northern front axis where the nartex abuts on, provides access to the sanctuary. Interior space is enlightened with casements on the body walls and dome's pulley. Middle window on the eastern front was converted into the door accessing to the shrine. There are stalactite courses which interspace in obtuse arch shape over hanger stones of blind arched lancets as one each. The mosque stands out with colourful stone craftsmanship on its outer fronts. The dome's pulley is supported by sixteen flying buttresses from outside. Eight of the windows between butresses are opened during renovation. The altar is meant to be noticed by being protruded in the absis shape from the wall facing Mecca. The minaret which is located in the northwest corner of the mosque sits on a square baseplate and has a cylindric body. The minaret has two accesses from two gates as one from the ground and one from the roof level. Project works of the mosque which is located at the center of Hüsrev Paşa Social Complex are prepared by Yüzüncü Y1l University in 2005. Renovation works are done by Bitlis Regional Directory of Foundation between the years of 2007 and 2009. In the Van Earthquake of 2011 the building's narthex and minaret sections are impacted serious static structural problems. All renovation works of Hüsrev Paşa Mosque are completed by Bitlis Regional Directory of Foundation in the year 2013 and it is opened to use for religious, social, touristic and cultural services for activities.
\end{abstract}

Structured Abstract: Hüsrev Pasha Social Complex, located at the Old City of Van, was built by Köse Hüsrev Mehmed Pasha the Van Governor, among the viziers of Suleiman I. (The Magnificent) between the years of 1567-1568. The Social Complex is a work of Sinan and consisted of a mosque, a madrassah, a shrine, an inn, a double-planned hammam, a almshouse, a elementary school and scholars' and guests' residencies.

The mosque, otherwise known as "Hüsreviye" and "Kurşunlu" makes core of the building. The court is reached through a gate located at the northern front axis adjacent to the narthex. There are five similar-

\footnotetext{
* Dr. Öğr. Üyesi, Van Yüzüncü Yıl Üniversitesi, Mimarlık ve Tasarım Fakültesi, Mimarlık Bölümü Asst. Prof. Dr. Van Yuzuncu Yil University, Faculty of Architecture and Design, Department of Architecture ORCID 0000-0001-6979-3342 sahozturk13@gmail.com

Cite as/ Atıf: Öztürk, Ş. (2020). Van Hüsrev Paşa Külliyesi Camii koruma ve onarım çalışmaları, Turkish Studies, 15(2), 1237-1268. https://dx.doi.org/10.29228/TurkishStudies.40204

Received/Geliş: 17 December/Aralık 2019

Accepted/Kabul: 25 April/Nisan 2020

Copyright (C) MDE, Turkey

Checked by plagiarism software

Published/Yayın: 30 April/Nisan 2020

CC BY-NC 4.0
} 
feature domes which are supported by lancet arches over metal truss bar posts in the north-east and northsouth directions and the narthex raised over six monolithic cylindrical narthex.

The mosque's court section is covered with an octagonal drum dome sitting on squinches at the corners of a square planned center. The gathering place level is reached through two symmetrical spiral steps that are located in the northern main outer wall. A rich stalactite motifs decorated altar alcove is located in the middle of the southern main wall through the centric axis direction of entrance gate. The altar is made out of limestone and stones are decorated with engraving technique. Pentagonal alcove is decorated with hexagonal stars.

Cubes are settled into the dome reciprocally for sound to diffuse uniformly. The minaret on the north-western corner of the mosque is formed as cylindrical body that is passed with a two-level footing on a square-prism base and has one balcony. As for the structural material for the mosque's building process that forms a prominent part of Hüsrev Pasha Social Complex; they used freestone, brick, rubber stone, wood, lead, tile, monolithic column, gold leaf and metal reinforcement materials. The lime mortar is used as a binding material in the structure.

Hüsrev Pasha Social Complex's Mosque has been renovated in various periods. These restorations are; 1967;

1-Renovation Works by Foundations Directory's Diyarbakır Regional Office in the year of

We have been founding out about minor-sized restoration works in the year of 1967 from articles. Because these works were not documented by Foundations Directory's Diyarbakır and Bitlis Regional Offices, scientific articles are taken as preliminar sources. When the mosque's dome had fractured and the narthex had Fallen in the year of 1960, renovations started under various projects by The Foundations Directory since 1967; however they were unfinished. Fallen spire of the minaret has been completed, missing stones are pieced out in the walls and cement substituted for the unqualified lime mortars between stones to reinforce during those works.

Missing stones from the building's outer main walls were pieced out by Ahlat Andesite stones in the region and were supported by a drum dome and 16 destroyed butresses around the drum were restored.

2002;

2- Excavation and Renovation works by Van Museum Directory between the years of 1996 and

"Excavation And Restoration Works For Hüsrev Paşa Social Complex" have been started in the year of 1996 and lasted until the year of 2002 under the administration of Van Museum Directory and scientific and technique responsibility of Yüzüncü Y1l University Faculty.

Conducted works are consisted of scouring, boring, documenting, water treatment, archaeological excavations, landscaping, classification of the materials disclosed during the excavation site, surveying, conservation and laboratory works ir general.

\section{7 and 2008;}

3- Renovation works by Foundations Directory's Bitlis Regional Office between the years of

The mosque's scouring and scientific excavation works have been completed in the year of 2002 and all architectural data about the building have been obtained. As a result of those architectural data, the building's survey, restitution and restoration projects have been prepared and approved by Regional Protection Board for Van's Cultural Heritage.

The building's restorations have been conducted by Foundations Directory's Bitlis Regional Office with the scope of prepared and approved application project in the year of 2007.

\section{2 and 2013;}

4- Renovation works by Foundations Directory's Bitlis Regional Office between the years of

The mosque which is located in the center of Hüsrev Pasha Social Complex was launched to worship after 2008 renovations and is not damaged by the Van Earthquake of 2011, with the size of 7,2. However the second earthquake of 5,6 size has severely damaged the minaret and the narthex falling them entirely and the main dome is mid-range damaged. 
In scope of this, architectural projects are prepared by Dr. Şahabettin ÖZTÜRK, Instructor and director of Restoration Programme at Van Yüzüncü Yıl University, Faculty of Architecture and Design's Department of Architecture. Static and structural analysis of the mosque have been prepared Prof. Dr. Alemdar BAYRAKTAR, instructor at Trabzon Karadeniz Technical University, Faculty of Engineering's Civil Engineering Department. Renovation and reinforcement works have been conducted and completed by Foundations Directory's Bitlis Regional Office in 2012 based on approved architectural and static projects for static problems of narthex and the dome. The minaret's renovation works have been recorded visually and by video as current building sections had been numbered in scope of the data in the surveying project digitally in the horizontal and alphabetically in the vertical fields. Then they are classified as each row in the determined locations of the ground under the audition of the project's author and control supervisors while dismantling works are being conducted.

Rebuilding minaret is completed by stainless steel plates from the base in the ground to the honeycomb section supporting each stone by lead binding. Limestones have been used substituting freestones because formers were suitable according to the same laboratory tests and latters were severely damaged during the earthquake and dismantling works and were unusable. All renovations works for Hüsrev Pasha Mosque have been completed by Foundations Directory's Bitlis Regional Office by the year of 2013 and it is launched to service for to be used in religious, social, touristic and cultural events.

Keywords: Architect Sinan, Hüsrev Pasha Mosque, Dome, Aks-i Seda (Echo) Boxes, Renovation.

Öz: Eski Van Şehri'nde yer alan Hüsrev Paşa Külliyesi, Kanuni Sultan Süleyman'ın vezirlerinden Van Beylerbeyi Köse Hüsrev Mehmed Paşa tarafindan 1567-68 yıllarında inşa edilmiştir. Mimar Sinan'ın eserleri olan külliye; cami, medrese, türbe, han, çifte hamam, imaret, sıbyan mektebi, muallim ve misafirhane bölümlerinden oluşmaktadır. "Hüsreviye" ve "Kurşunlu" adlarıyla anılan cami, külliyenin çekirdeğini oluşturur. Merkezi kare plânlı olan cami, tromplar üzerine oturan tek kubbeyle örtülmüştür. Harime, son cemaat yerinin bitiştiği kuzey cephesi ekseninde bulunan bir kapıyla girilmektedir. İç mekân, beden duvarlarında ve kubbe kasnağında açılan pencerelerle aydınlatılmıştır. Cephelerdeki sivri kör kemerli alt pencerelerin atkı taşları üzerinde, basık kemer biçiminde boşluk bırakan birer mukarnas dizisi mevcuttur. Cami, dış cephelerindeki renkli taş işçiliği ile dikkat çekmektedir. Kubbe kasnağı dıştan on altı payanda kemeri ile desteklenmiştir. Payandalar arasındaki pencerelerden sekizi onarım sırasında açılmıştır. Mihrap, kıble duvarından yarım kule şeklinde dışa taşırılarak vurgulanmak istenmiştir. Caminin kuzeybatı köşesinde yer alan minare kare kaideli, silindirik gövdelidir. Minareye zemin ve çatı seviyesinden iki kapı ile giriş sağlanır. Hüsrev Paşa Külliyesi’nin merkezinde yer alan caminin restorasyon uygulama proje çalışmaları 2005 yılında Yüzüncü Yıl Üniversitesi tarafından hazırlanmıştır. Bitlis Vakıflar Bölge Müdürlüğü tarafından onarım çalışmaları 2007-09 yıları içerisinde yapılmıştır. 2011 yılında meydana gelen Van depreminde yapının son cemaat ve minare bölümünde ciddi statik yapısal sorunlar oluşmuştur. Hüsrev Paşa Camisi tüm onarım çalışmaları 2013 yılında Bitlis Vakıflar Bölge Müdürlüğü tarafından tamamlanarak, günümüzde dini, sosyal, turizm ve kültürel aktivitelerde kullanılarak hizmet vermektedir.

Anahtar Kelimeler: Mimar Sinan, Hüsrev Paşa Camii, Kubbe, Aks-i Seda Küpleri, Koruma.

\section{Giriş}

Selçuklu ve Osmanlı yönetimindeki tüm yerleşim alanlarda olduğu gibi, Van Gölü ve Havzası'ndaki birçok kentte cami inşa edilmiştir. İslam mimarisinde cami ve mescit gibi mimarı yapılarını önemli bir yeri vardır. Farklı dönemlerde inşa edilen cami ve mescitlerin Van il merkezi ve merkez dışı yerleşim alanlarındaki sayısı, mimari form ve fonksiyonel özellikleri hakkında yeteri kadar bilgiye sahip değiliz. Çeşitli yazılı kaynak ve belgelerde Van ili ve çevresinde çok sayıda cami ve mescidin inşa edildiği bilinmektedir.

Birçok cami ve mescit vakıf aracılığıyla inşa edilmiş ve inşa edildiği dönemdeki toplumun dini ve sosyal ihtiyaçlarını karşılaşmanın dışında, dönemin mimari, kültürel, ekonomik, siyasi vb. ortamı hakkında da geniş bilgi vermektedir. 1899 yılındaki Van Vilayeti Salnamesinde ve diğer tarihi kaynaklarda elde edilen bilgiler ışığında 54 adet yapının 27'si cami, 27'si ise mescit olduğu 
tespit edilmiştir (Van Vilayet Salnamesi 1315, 1995: 69). Eski Van şehrinde ve kalesinde yer alan camiler ise on adettir. Bunlar;

1. Ulu Cami; Cami-i Kebir veya Şah-1 Ermen Camii olarak da bilinen yap1, Eski Van Şehri'nde yer almaktadır (Şekil 1). I. Sökmen (1100-12) ya da II. Sökmen (1128-85) döneminde yaptırılmış olması kuvvetle muhtemeldir (Öztürk, 1996: 30).

2. Kızıl Cami; Eski Van Şehri'nin doğu kısmında bulunan Tebriz Kapısı Mahallesi’ndeydi (Şekil 1). Günümüzde medrese mevcut değildir (Öztürk, 2019: 452-469).

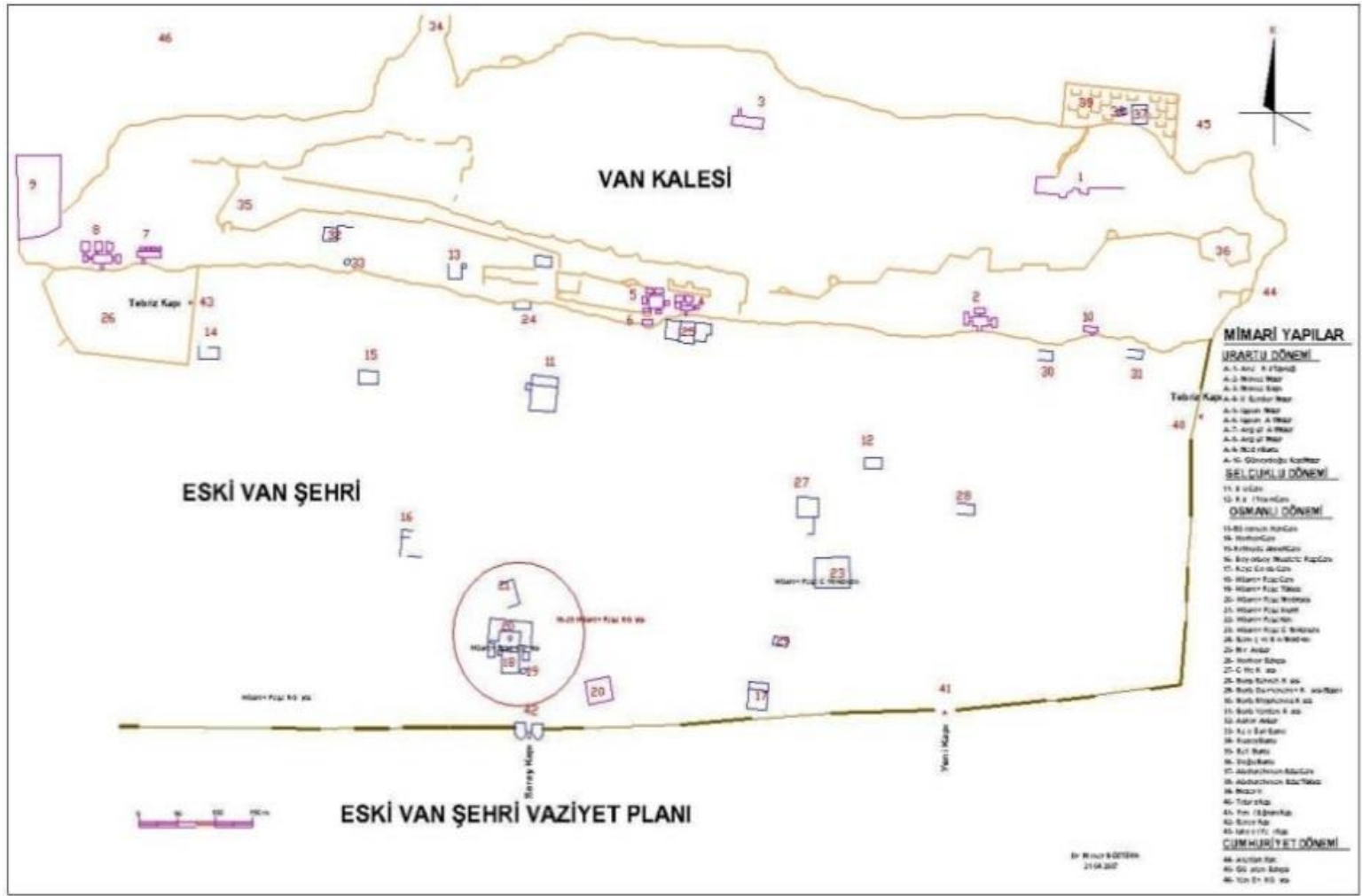

Şekil 1. Van Kalesi-Eski Van Şehir Vaziyet Planı (Ș. Öztürk)

3. Süleyman Han Camii; Tarihi Van Kalesi üzerinde engebeli bir alanda yer almaktadır (Şekil 1). İnşa tarihi kesin olarak bilinmemektedir. Yap1, Kanun-i Sultan Süleyman'ın Irakeyn Seferi sırasında Mimar Sinan tarafından esaslı olarak onarılmıştır. 2010 yılında Van Valiliği tarafından onarılarak ibadete açılmıştır (Öztürk, 2012: 34-54).

4. Hüsrev Paşa Camii; Van Beylerbeyi Hüsrev Paşa tarafindan, H. 975, M. 1567-68 tarihinde inşa edilmiştir. Cami, Eski Van Şehri Orta Kapı Mahallesi’nde yer almaktadır (Şekil 1), (Ağaoğlu, 2007: 328-330).

5. Kaya Çelebi Camii; Cami H.1071, M. 1660 yılında Kaya Çelebi Koçi Bey tarafından yapılmaya başlanmış, ancak Koçi Bey1563 yılında devlete karşı isyanda diğer yetkililerle birlikte idam edilmiştir. Cami inşaatı daha sonra Cem Dedemoğlu Mahmut tarafindan tamamlanmıştır (Öztürk, 1996: 19). Kaya Çelebi Camii, 2011 Van Depremi'nde ağır hasarlı olarak etkilenmiş, 2014 yılında yapılan onarımlarla günümüzde kullanılmaktadır (Şekil 1).

6. Abbas Ağa Camii; Abbas Ağa tarafından 1655'den önce yaptırılan cami, Eski Van Şehri İskele Mahallesi’nde yer almaktadır (Şekil 1). Yapının kazı ve onarım çalışmaları Bitlis Vakıflar Bölge Müdürlüğü tarafından devam etmektedir (Öztürk, 2013: 9-57). 
7. Sinaniye Camii; Cami, Eski Van Şehri'nin güneybatı bölümünde yer almaktadır (Şekil 1). Van Kadısı Ömer Efendi’nin talebi üzere H. 1087 M. 1677 yılında Sinan Kethude tarafindan inşa edilmiştir. Gününüzde sadece beden duvarının bir bölümü ayakta olup, tamamıyla yıkıktır (Öztürk, 1999: 14-19).

9. Horhor Camii; Eski Van Șehri, Horhor Bahçesi'nin hemen yanında yer almaktadır (Şekil 1). Cami, XVIII. Yüzyılı sonlarında inşa edilmiştir. 2014 y1lında Bitlis Vakıflar Bölge Müdürlüğü tarafindan onarılan yapı, günümüzde kullanılmamaktadır (Öztürk, 2018: 1753-1772).

10. Şeyh Abdurahman Gazi Camii; Tarihi Van Kalesi’nin kuzeydoğu köşesinde yer alan yap1, XV. yüzyılda Bağdat'tan geldiği ve Van'a yerleşerek halkı irşad ettiğine inanılan Şeyh Abdurahman Gazi adına yaptırılmıştır (Uluçam, 2000: 60). Yapı günümüzde ibadet amaçlı faaliyetlerde kullanılmaktadır (Şekil 1).

Hüsrev Paşa Külliyesi'nin yer aldığı Eski Van Şehri, tarihi Van Kalesi'nin güneyinde yaklaşık $365.000 \mathrm{~m}^{2}$ lik alan üzerine kurulmuştur (Şekil 1). Şehrin doğusu, güneyi ve batısı surlarla, kuzeyi ise Van Kalesi ile çevrelenmiştir. Şehrin girişi doğu, güney ve batı surlarda açılan dört ana kapı ile sağlanmaktadır (Öztürk ve Mızrak, 2001: 32-34).

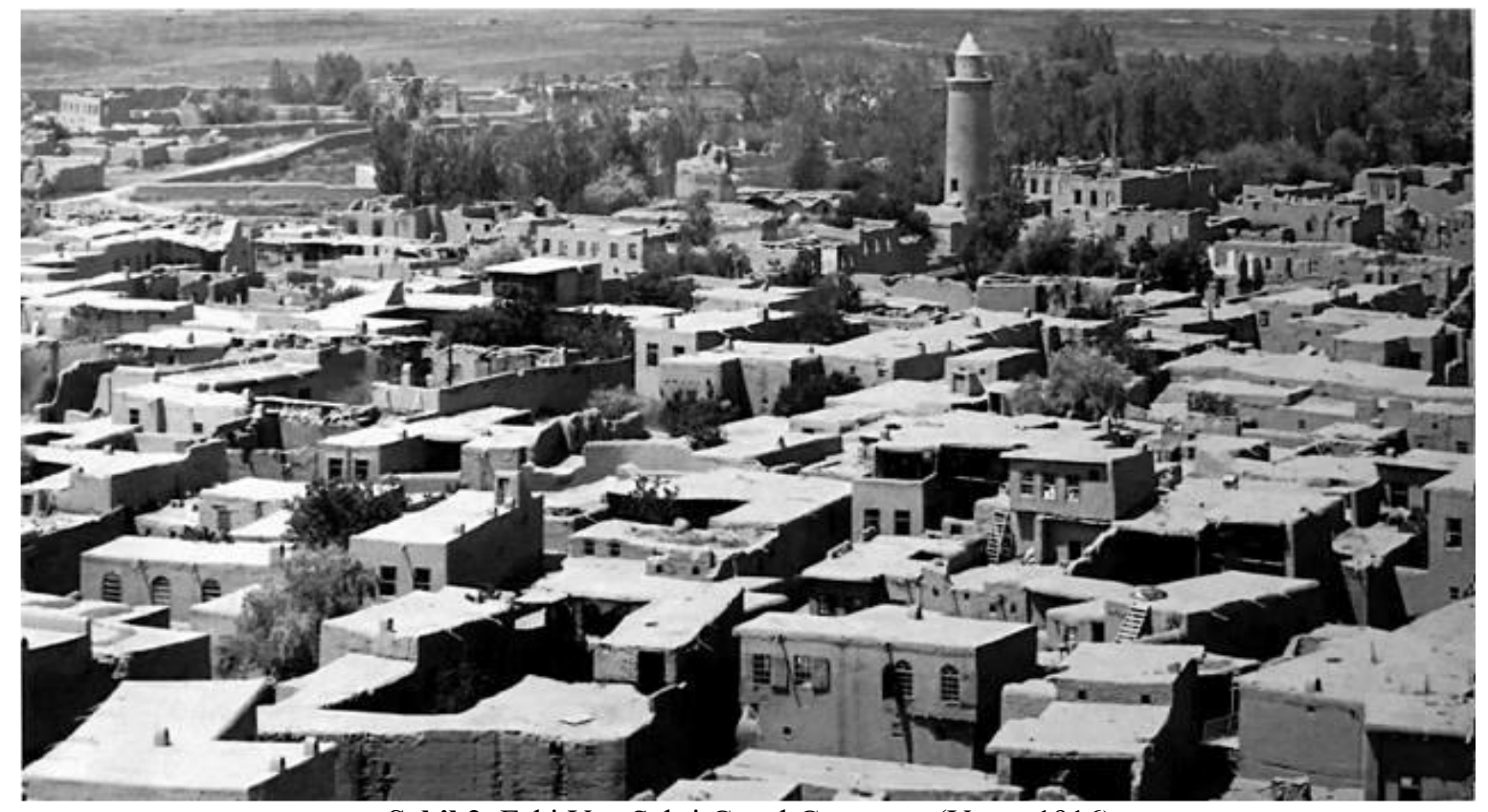

Şekil 2. Eski Van Şehri Genel Görünüşü (Vruyr:1916)

Eski Van şehri topografik olarak az eğimli bir yapıya sahiptir. Arazinin eşyükselti eğrileri kuzeyden bir uçurum gibi aşağıya doğru inen kayalıkların dibinden, önce doğu-batı yönüne, sonra güneye, kuzeye ve tekrar güneye doğru kıvrılıp genişleyerek devam etmektedir (Şekil 1-3).

Şehirde Türklerle Ermeniler yan yana, iyi komşuluk ilişkisi içinde yüz yıllarca birlikte kardeşçe yaşamışlardır. Şehrin doğu bölgesinde Ermeniler, kuzeybatı köşesinde Kürtler, orta kısımlarında ise Türkler ağırlıklı olarak yaşamışlardır (Günel, 1993: 41-48). Şehrin nüfusunun büyük bir bölümünü Müslümanlar oluşturmakla birlikte y1llara bağl1 olarak nüfusun sürekli değiştiği çeşitli kaynaklarda görülmektedir (Öztürk, 2004: 52-54).

1915-18 Rus-Ermeni işgali sırasında Eski Van Şehri içinde yer alan tüm mimari yapılar yakı1ıp yıkılarak yok edilmiştir. 


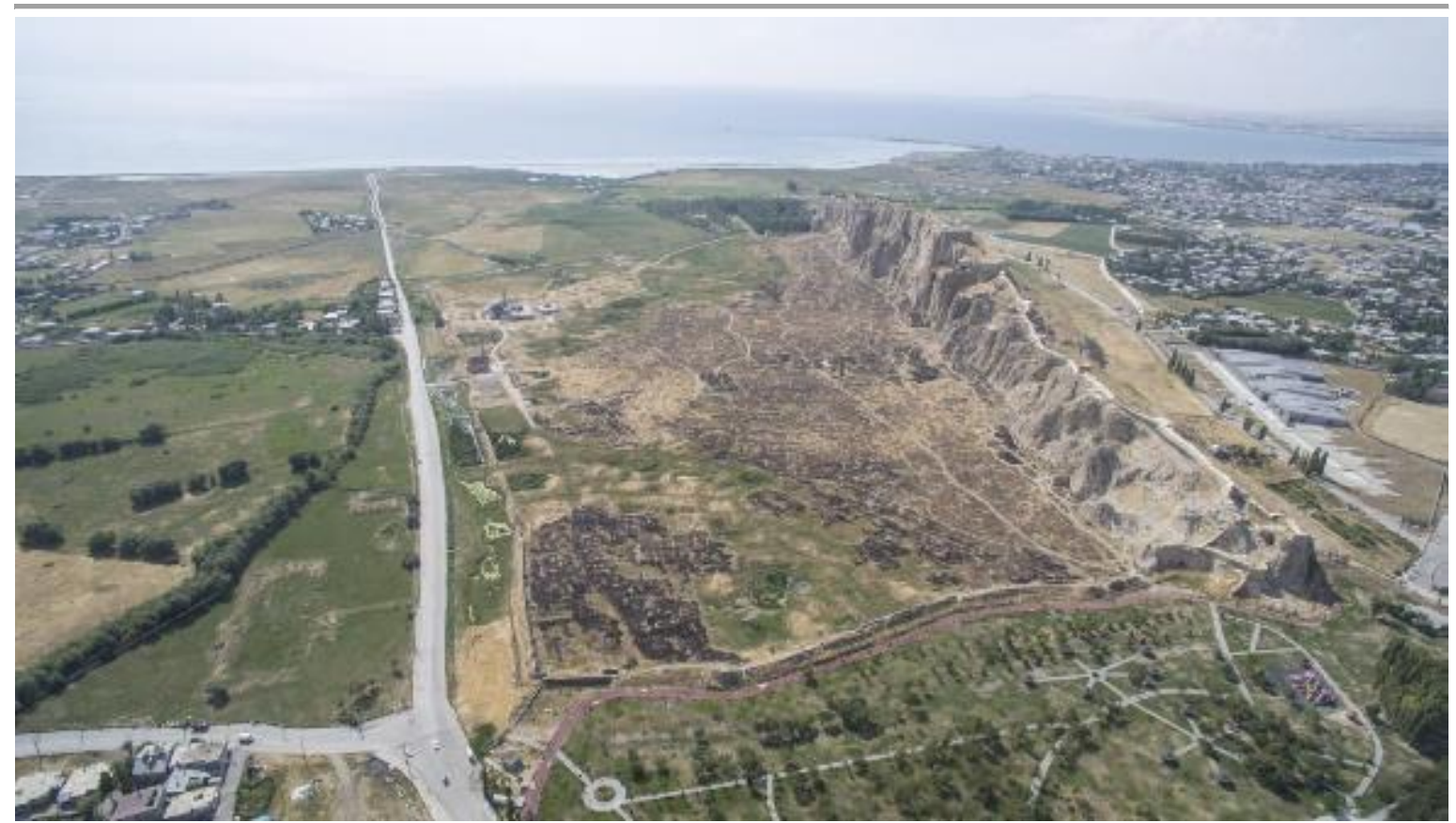

Şekil 3. Eski Van Şehri ve Kalesi Genel Görünüşü (VANTAM Arşivi)

$\mathrm{Bu}$ tarihten 2010 yılına kadar doğanın ve diğer her türlü olumsuz koşulların etkisi altında büyük bir bölümü yıkılan mimari yapılardan biri de Hüsrev Paşa Külliyesi'nin önemli bir bölümünü oluşturan klasik dönem dini mimari özelliklerine göre inşa edilmiş camidır (Şekil 1-4).

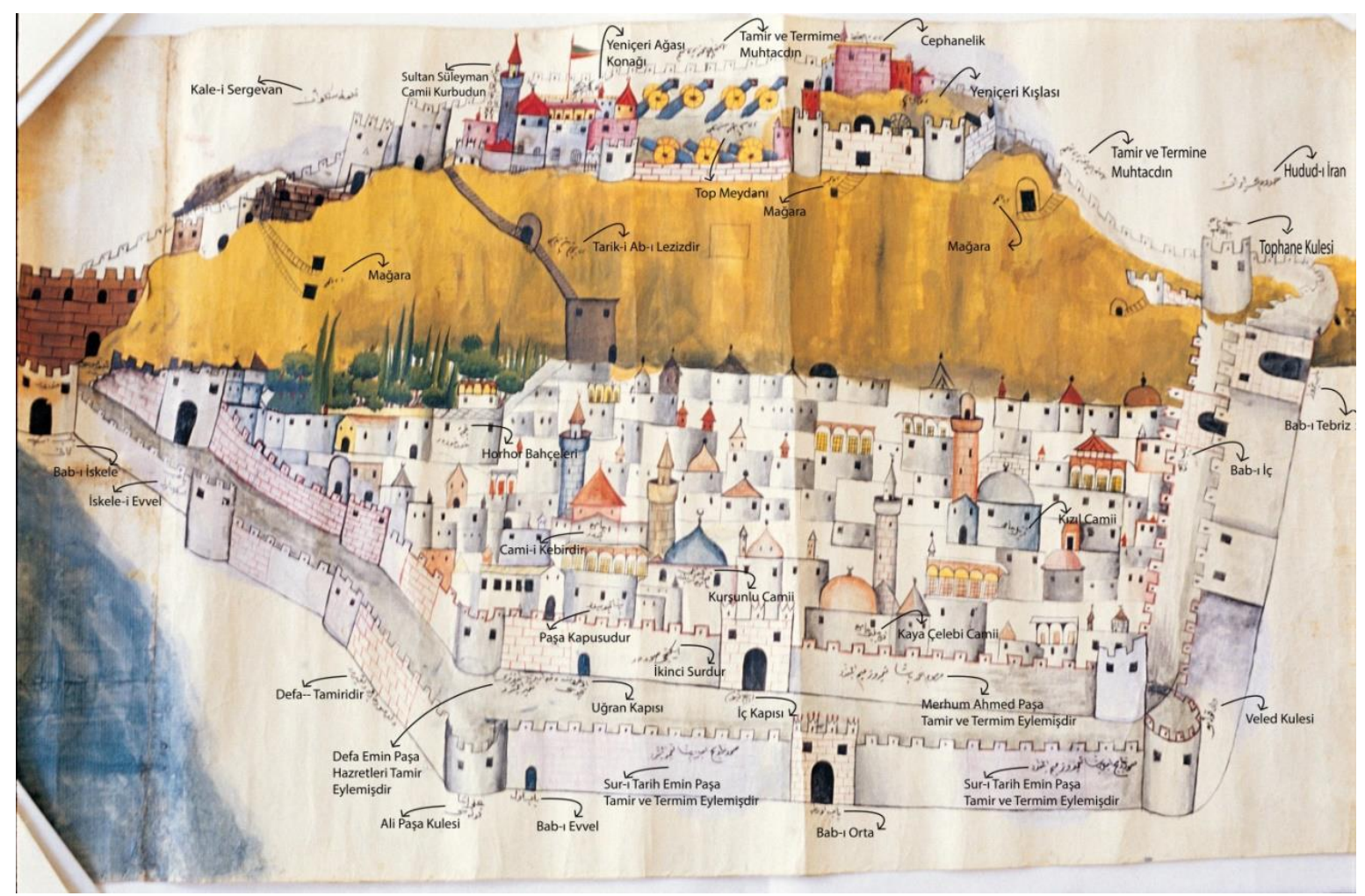

Şekil 4. Kala-i Sengi Van Minyatürü (Topkapı Saray Arşivi)

Hüsrev Paşa Külliyesi'nin hamam ve han yapılarının kazı ve temizlik çalışmaları Van Valiliği il Özel İdaresi’nin maddi desteği Van Müze Müdürlügü başkanlığında, Dr. Mimar ve Sanat 
Tarihçisi Şahabettin Öztürk'ün bilimsel sorumluluğunda 2005-08 yılları arasında yapılarak tamamlanmıştır. Külliyenin merkezinde yer alan merkezi planlı caminin rölöve, restitüsyon ve restorasyon uygulama projeleri, Hüsrev Paşa Külliyesi'nin bilimsel kazı ekip mimarı olan ve Van Yüzüncü Yıl Üniversitesi Mimarlık ve Mühendislik Fakültesi Mimarlık Bölümü öğretim Üyesi Dr. Şahabettin Öztürk tarafından hazırlanmıştır.

Hazırlanan uygulama projeleri 2002 y1lında Diyarbakır, 2008 y1lında ise Van Kültür Varlıkları Bölge Kurul Müdürlüğü tarafından onaylanmıştır.

\section{Konumu}

Hüsrev Paşa Külliyesi'nin merkezinde yer alan cami, tek kubbeli, harim ve önünde beş bölümlü son cemaat yeri ile kuzeybatı köşedeki ve tek şerefeli minareden oluşmaktadır. Caminin güneyinde Saray Kapısı, doğusunda türbe ve han, kuzeyinde avlu, şadırvan ve medrese, batısında ise hazire bölümü yer almaktadır (Öztürk, 1996: 14-19).
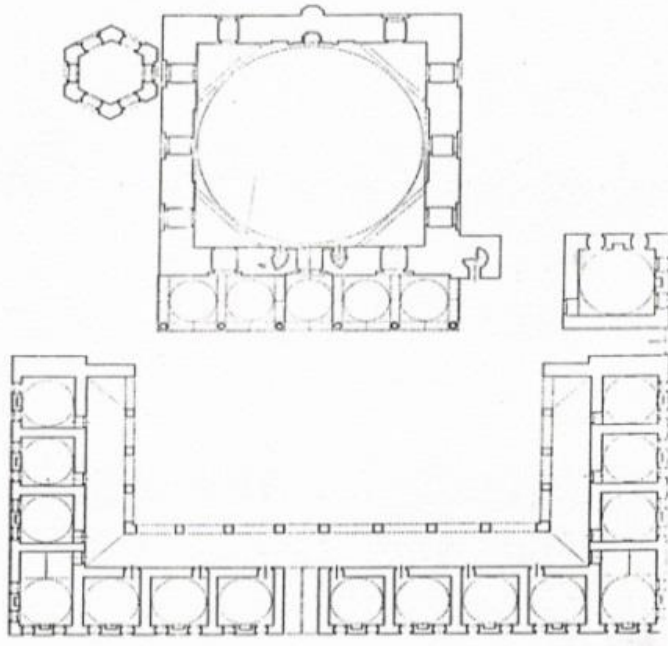

Şekil 5. Hüsrev Paşa Külliyesi Vaziyet Planı (A. S. Ülgen)

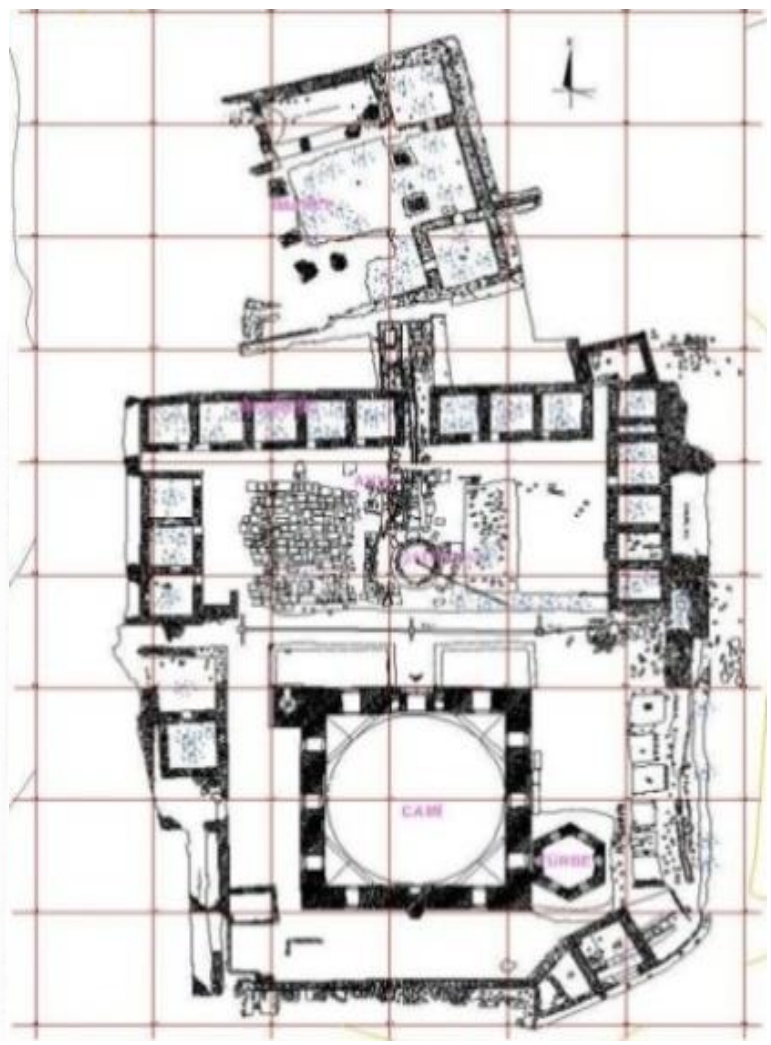

Şekil 6. Hüsrev Paşa Külliyesi Rölöve Vaziyet Planı (Ş. Öztürk)

Vakıflar Genel Müdürlüğü Bitlis Vakıflar Bölge Müdürlüğü tarafindan cami onarımı 200811 yılları arasında tamamlamış olup, günümüzde aktif olarak sosyal ve kültürel amaçlı faaliyetlerde yöre halkı tarafından kullanılmaktadır (Şekil 5,6).

\section{Tarihçe}

Külliye vakfiyesinde yapı topluluğu merkezinde yer alan cami, külliyenin diğer yapıları ile birlikte H.975-M.1567 yılında Mimar Sinan tarafından planlandığı ve bölge mimarları tarafindan inşa edildiği bilinmektedir (Şekil 7,8). Hüsrev Paşa Külliyesi, Kanuni Sultan Süleyman'ın vezirlerinden Van Beylerbeyi Köse Hüsrev Mehmed Paşa tarafindan, 1567-68 yılları arasında yaptırılmıştır (Sönmez, 1988: 84). 


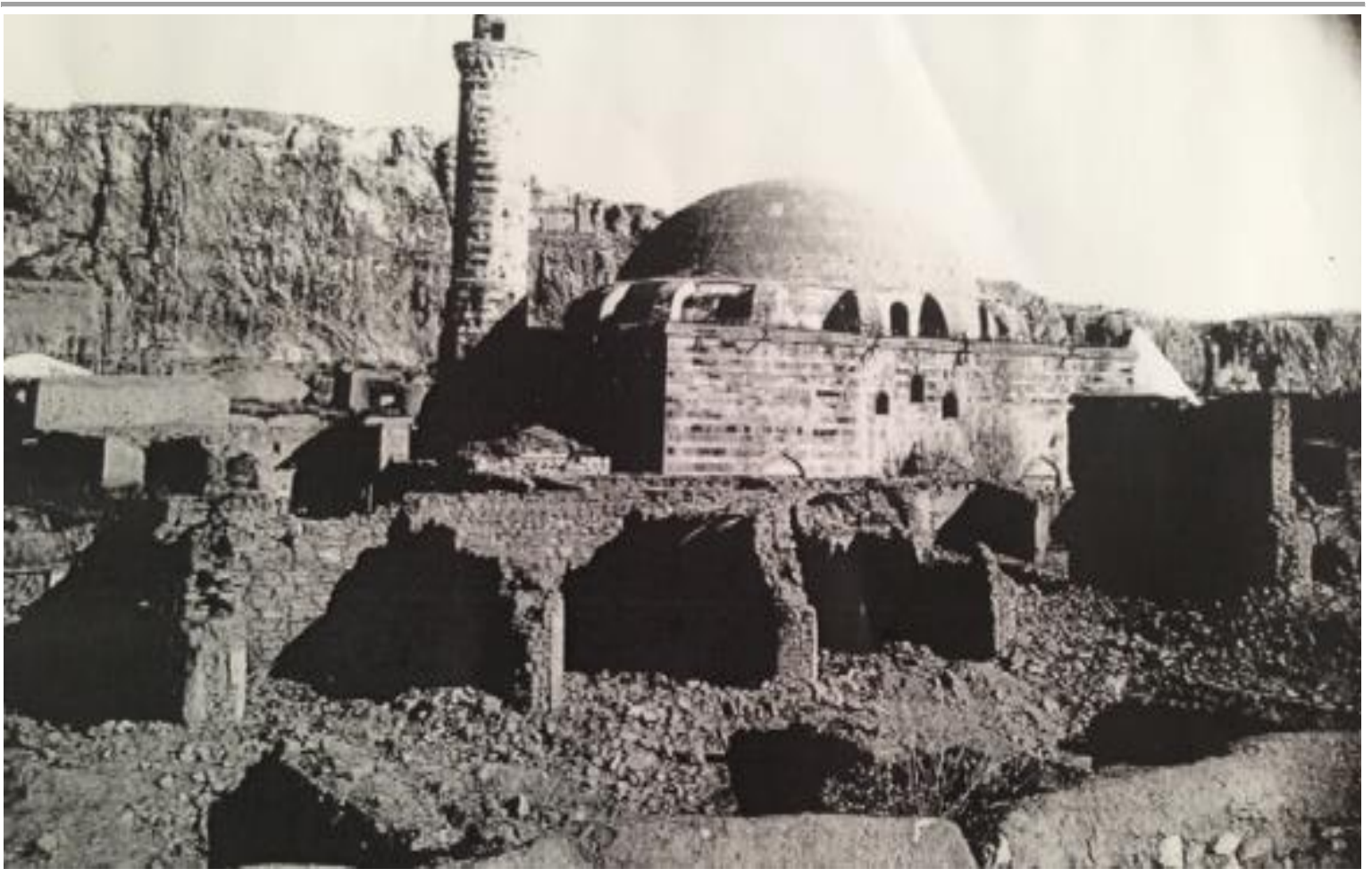

Şekil 7. Hüsrev Paşa Külliyesi Güneybatı Genel Görünüşü (Anonim)

Giriş kapısı üzerinde sülüs harflerle yazılmış iki beyitlik tarih kitabesi yer almaktadır. Farsça yazılı kitabede H.975 M. 1567 tarihi ile Beylerbeyi Hüsrev Paşa ve hattat Yusuf'un adları okunmaktadır (Uluçam ve Kavakl1, 2000: 11-16).

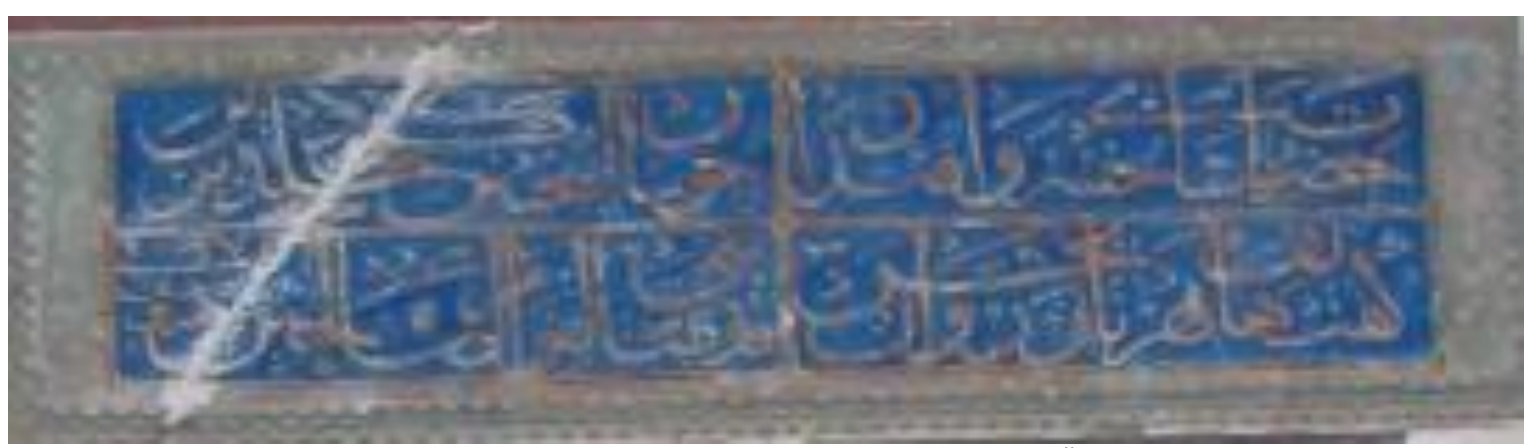

Şekil 8. Hüsrev Paşa Camii Kitabe Görünüşü (Ş. Öztürk)

"Hazret-i Paşa-ı Hüsrev iktidar Çün bina inçünin kerd huld-i berrin

Güft hatif behar târıheş ruvat Kâd bena beyten li-kavm-is salıhin Ketebe Yusuffi 975"

Tercümesi

"İktidar sahibi Hüsrev Paşa Hazretleri baki ve yüce rabbin rızası için bina etti

Hafiften gelen tarihi için şöyle dediler "Salihler topluluğu için bir ev (mescid) inşa etti" Yusuf yazdı tarih 975 (1567-68)" ifadeleri yer almaktadır (Uluçam, 2002: 5,6). Kaynaklarda yapının mimarı olarak Van Eyaleti Hassa mimarı Mimar Selman'ın görevlendirildiği ve cami planının başkent İstanbul'dan gönderildiği belirtilmiştir (Boran, 1996, 16).

Cami, 08.06.1979 tarih ve A-1673 sayılı karar ile anıt yapı olarak tescil edilmiştir. Yapıya ait bilimsel kazı ve temizlik çalışmaları 1996-2002 yılları arasında Van Müze Başkanlı̆̆ı'nda ve Yüzüncü Yıl Üniversitesi'nin Sanat Tarihi, Arkeoloji ve Restorasyon bölümleri öğretim elemanlarının katılımı ile yapılarak tamamlanmıştır. 


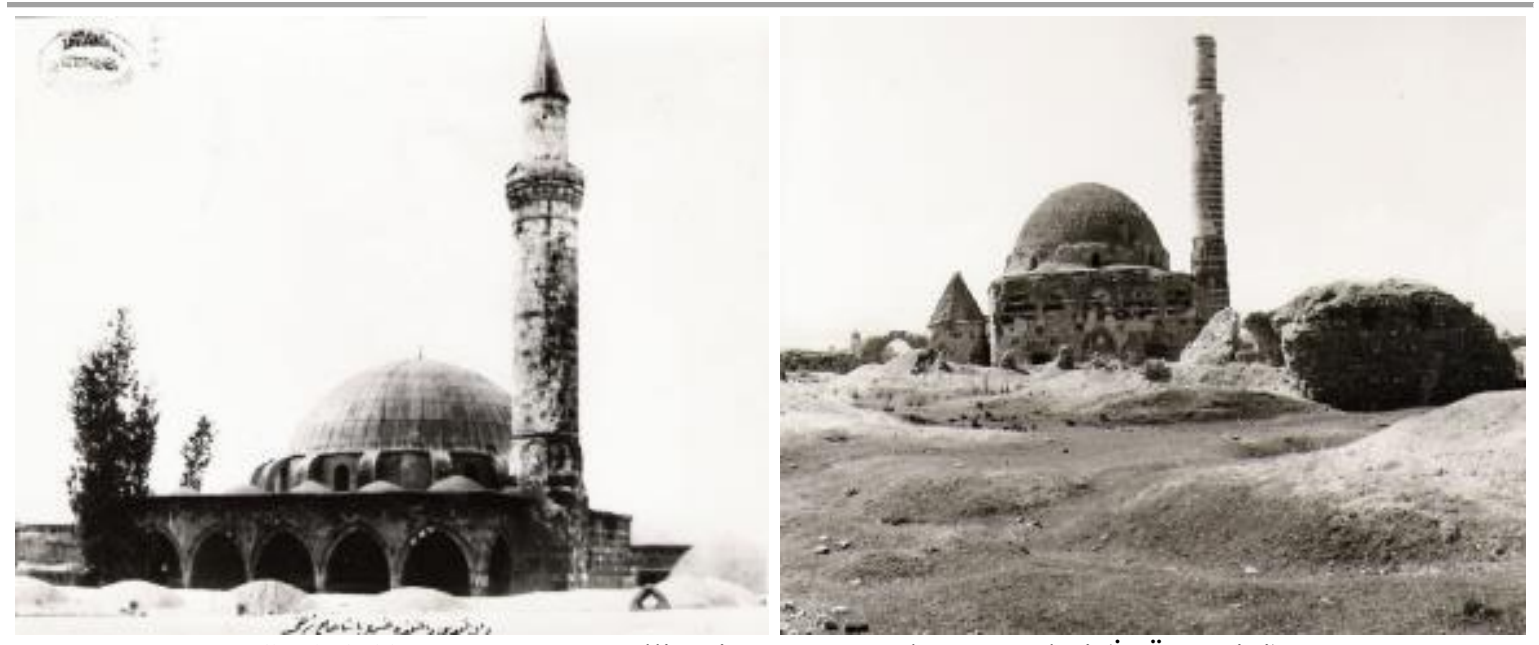

Şekil 9,10. Hüsrev Paşa Külliyesi Kuzey Genel Görünüşleri (İ. Ü. Arşivi)

960 yılında Ayntab Beyi, ardından beylerbeyi, damad-ı padişahî ve defterdar olan Köse Hüsrev Paşa 970-994 arasında farklı yerleşim birimlerinde valilik görevinde bulunduktan sonra 995'te (1587) Van Valisi iken İran savaşında şehit olmuş ve banisi olduğu külliye içindeki türbeye gömülmüştür (Süreyya, 1996: 684).

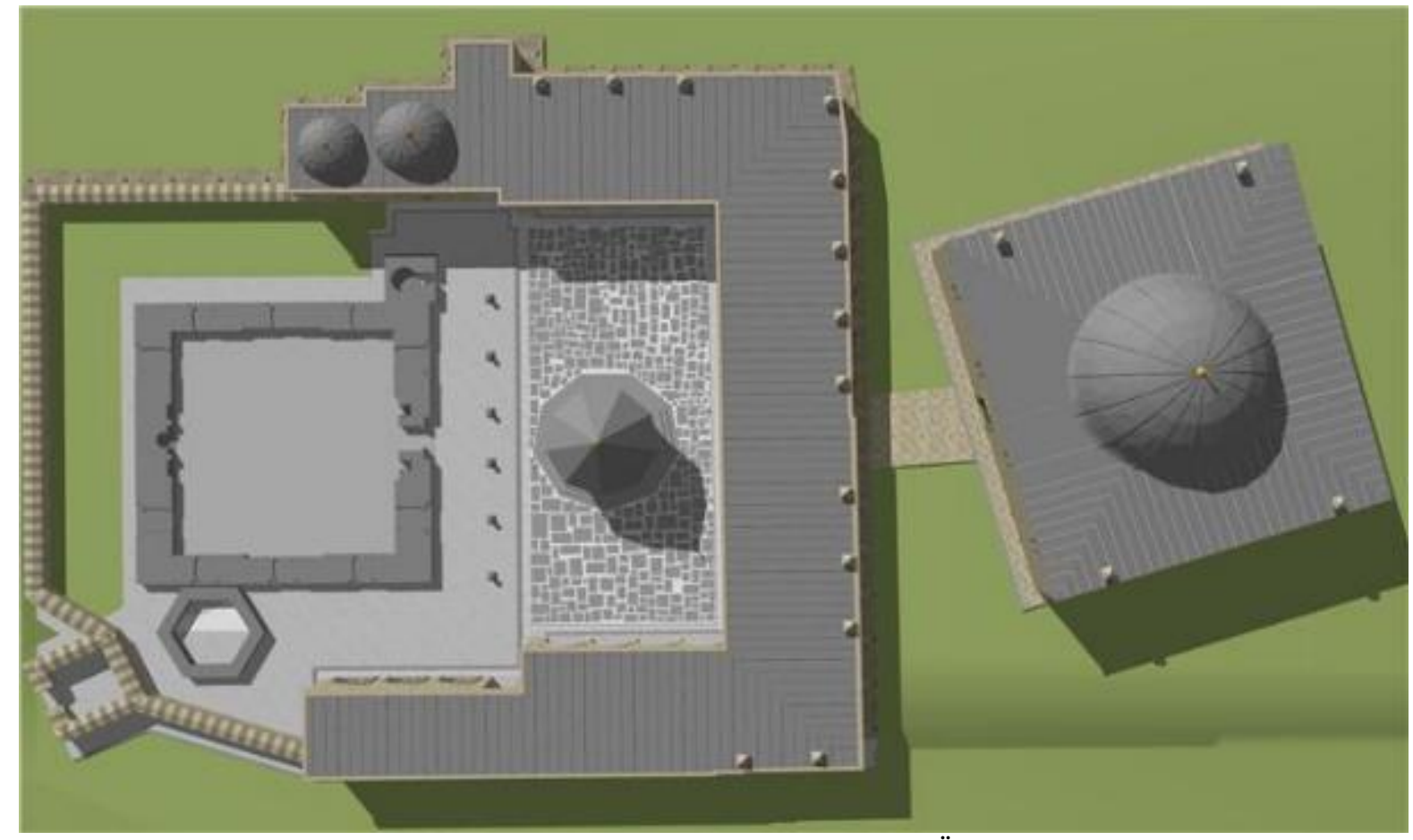

Şekil 11. Hüsrev Paşa Külliyesi Vaziyeti (Ş. Öztürk)

Hüsrev Paşa Külliyesi, Tuhfet ül-Mi'marin'de Mimar Sinan eserleri arasında 72. sırada geçmekte ve külliyenin cami, medrese, türbe, imaret, sıbyan mektebi, daru'l-kurra ve misafirhaneden oluştuğu belirtilmektedir (Kuran, 1986: 257).

Yap1 her ne kadar Mimar Sinan'1n eseri olarak belirtilse de, Mimar Sinan'a atfedilen diğer yapılar gibi, Hüsrev Paşa Külliyesi'nin de Sinan'ın onayladığı bir mimar tarafından inşa edilmiş olabileceği düşünülmektedir (Eyice, 1999: 50), (Şekil 7-12). 


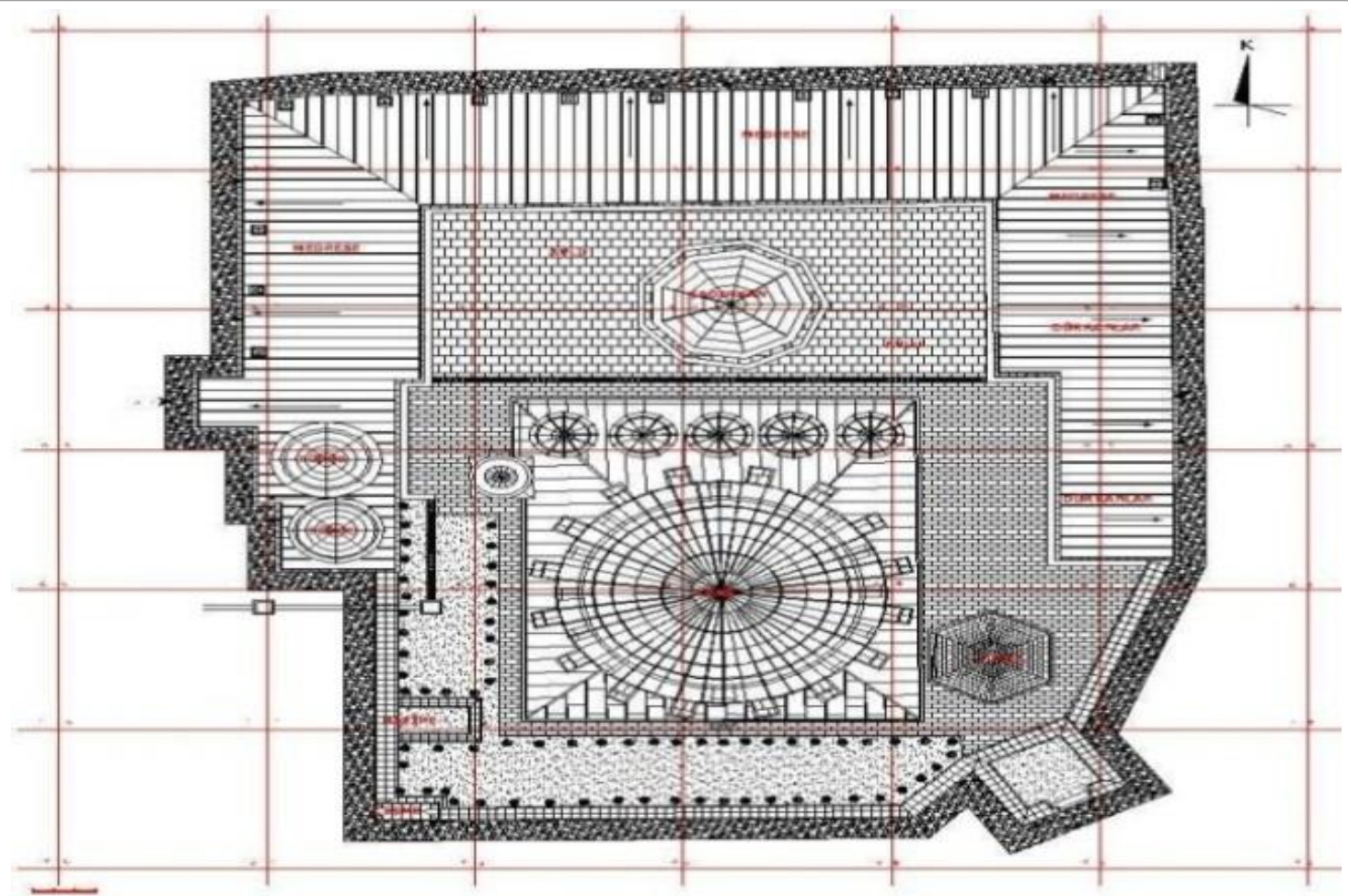

Şekil 12. Hüsrev Paşa Külliyesi Vaziyet Planı (Ş. Öztürk)

\section{Yapının İncelenmesi}

\subsection{Plan}

Hüsrev Paşa Külliyesi'nin merkezinde yer alan camiye kuzeyde son cemaat bölümünden girilmektedir. Son cemaat bölümü 4.02x19.63 m. ölçülerinde dikdörtgen formunda biçimlenmiştir.

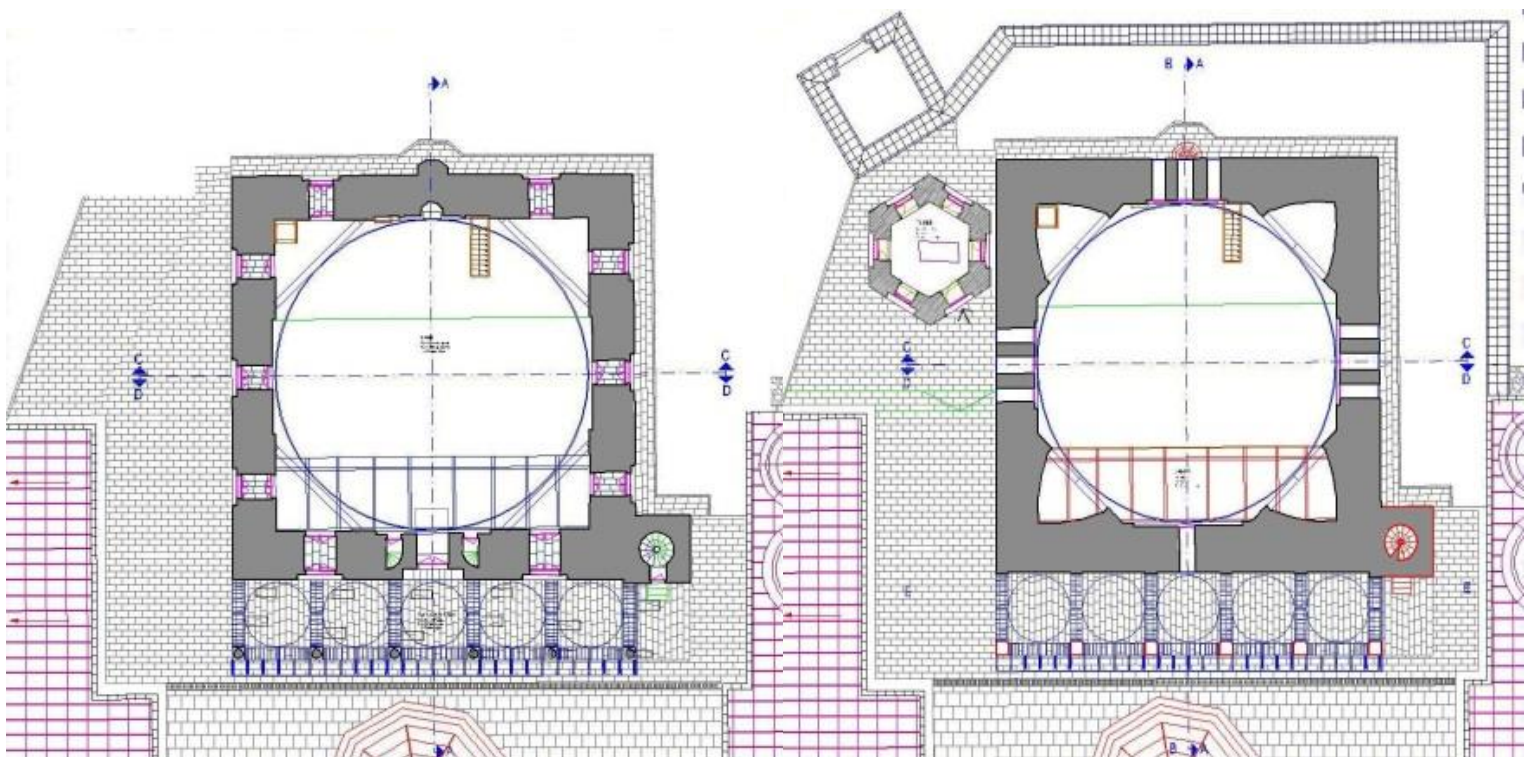

Şekil 13,14. Hüsrev Paşa Camii Zemin ve Mahfil Kat Planı (Ş. Öztürk)

Altı adet yekpare silindirik sütunları üzerinde yükselen son cemaat bölümü, doğu-batı ve kuzey-güney istikametinde oluşan metal gergi çubuklar ve sivri kemerlerle desteklenen beş adet benzer mimari özellikte kubbeyle örtülüdür (Şekil 13,14). Son cemaat bölümünün ortasındaki cami girişinin her iki doğu ve batı platformu zeminden $0.34 \mathrm{~m}$. daha yüksek planlanmıştır. 
Cami girişinin ana kapısı beden duvarının içerisine $0.53 \mathrm{~m}$. derinlikte yerleşen sivri kemerden oluşmaktadır. $1.50 \mathrm{~m}$. genişlikte olan giriş kapısı çift kanatlı ceviz doğramalı ve dekoratif süslemelidir. $15.24 \times 15.24 \mathrm{~m}$. ölçülerindeki kare plan harim olup, köşelerden tromplarla geçilen sekizgen kasnak üzerinde, $15.20 \mathrm{~m}$. çapında kubbe ile örtülüdür.

Kuzey beden duvarının içine yerleşen $0.66 \mathrm{~m}$. genişlikteki simetrik iki helezonik merdivenler ile mahfil katına çıkılmaktadır (Şekil 13,14). Tamamıyla ahşap doğramadan imal edilmiş mahfil bölümü, 3.60x15.24 m. ölçülerindedir. Mahfil katı, $0.12 \times 0.12 \mathrm{~m}$. ölçülerindeki karşılıklı 20 adet ahşap dikme üzerinde yer almaktadır.

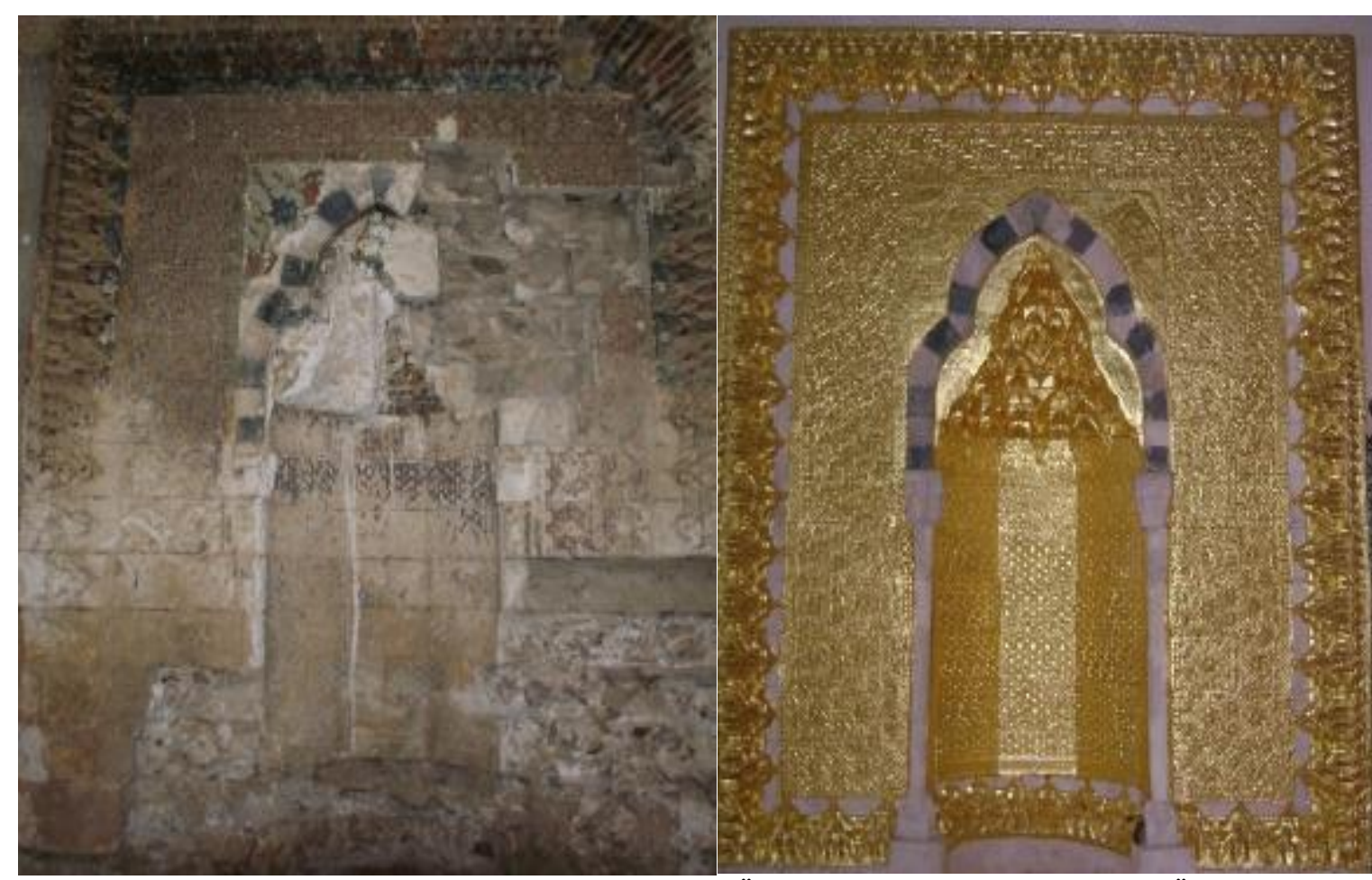

Şekil 15,16. Hüsrev Paşa Camii Mihrap Onarım Öncesi ve Sonrası Görünüşleri (Ş. Öztürk)

Cami giriş alanı harim bölümüne doğru $1.24 \mathrm{~m}$. devam ederek $0.10 \mathrm{~m}$. daha alt kotta yer almaktadır. İç mekan zemin kotu giriş kapısından $10.41 \mathrm{~m}$. devam ederek doğu-batı istikametinde $0.18 \mathrm{~m}$. daha yükselerek bir kadame oluşturmaktadır. Cami içerisindeki bu kot farkı eski Van şehri içerisinde bulunan diğer tarihi camilerden yalnız Hüsrev Paşa Cami'inde olması, camide ibadet dışında adalet ve hukuk görüşmelerinin yapıldığı tek cami olmasından kaynaklanmaktadır. Düşük kotta davalı ve davacılar, yüksek kotta ise kadı ve hüküm verici görevliler yer almaktadır (Şekil 13,14).

Giriş kapısının merkez aksı doğrultusunda güney beden duvarının ortasında $0.10 \mathrm{~m}$. içe taşıntılı 2.26x3.97 m. ölçülerinde altın varaklı zengin dekoratif mukarnas süslemeli mihrap nişi bulunmaktadır. Mihrap, güney beden duvarında $0.74 \mathrm{~m}$. dışa taşıntılı olarak inşa edilmiştir. Mihap nişi, 1.06 genişlikte $0.65 \mathrm{~m}$. derinlikte beş kenarlı köşelerde sütünceler yardımıyla iki dilimli sivri kemer ile çevrelenmiştir (Şekil 15,16).

Mihrap kalker taşından yapılmış olup, taşlar oyma tekniğinde süslenmiştir. Beşgen nişin içerisi altı kollu yıldızlarla doldurulmuştur. Üstten üç dilimli kemerle kuşatılmış, mukarnaslı bir kavsarayla sonlanmıştır. İçteki bordürde sekizgen geçmeler ve ortalarına gül bezekler yapılmıştır. Dıştakinde ise, mukarnas dizisinden oluşan bir bordür yer almaktadır. Mihrabın mukarnas kavsarası alt sırada tahrip edilmiştir (Şekil 17-19). 


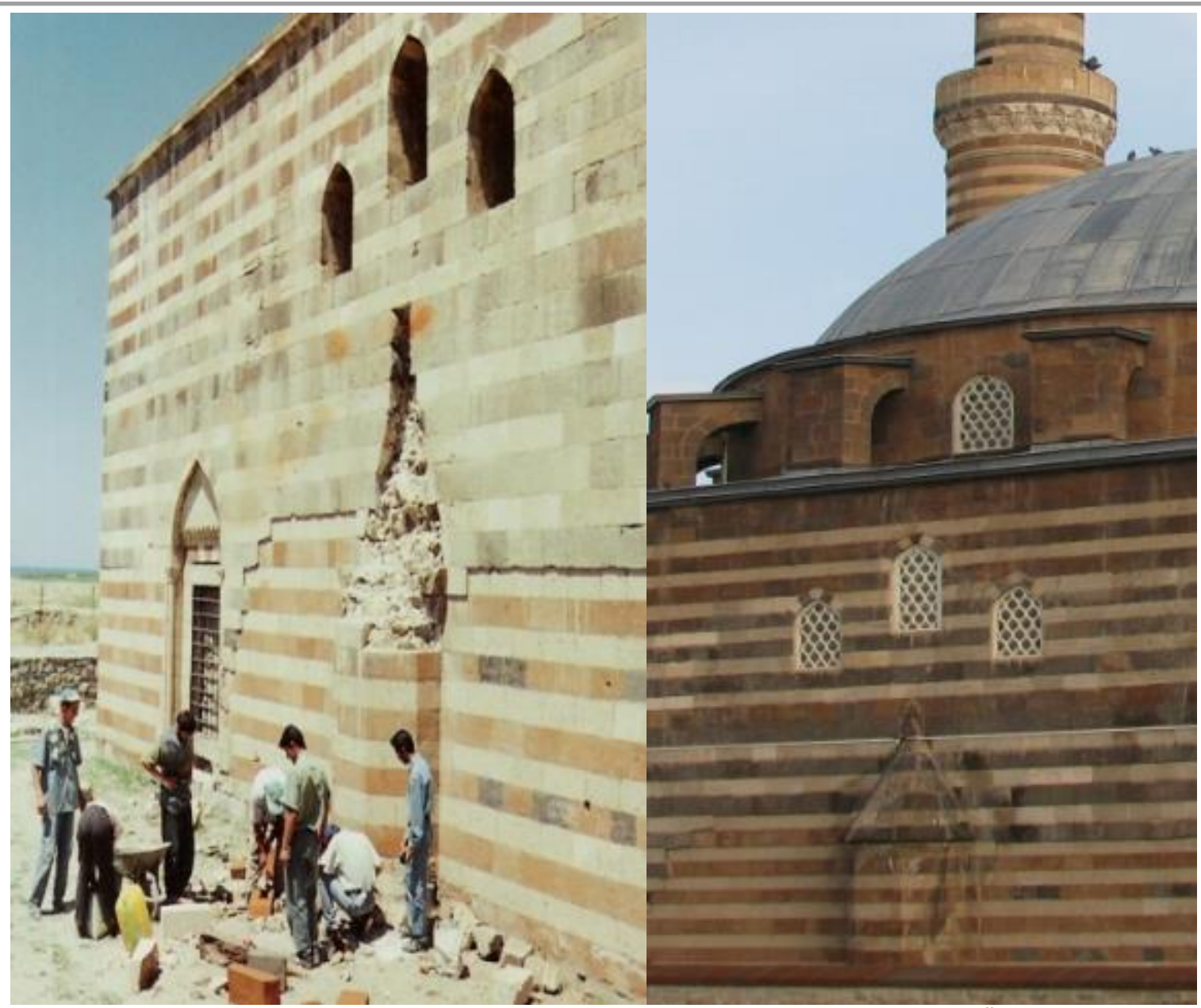

Şekil 17,18. Hüsrev Paşa Camii Mihrap Dış Cephe Onarım Görünüşleri (Ş. Öztürk)

Cami iç mekân doğal aydınlatılması alt kotta doğu-batı beden duvarlarında üçer, kuzeygüney beden duvarlarında ise karşılıklı ikişer toplam 10 adet $1.10 \mathrm{~m}$. genişlikteki pencere ile sağlanmaktadır. Üst kotta ise doğu, batı ve güney beden duvarlarında üçlü grup halinde, kuzey beden duvarında ise karşl1ıklı tek toplam 10 adet $0.70 \mathrm{~m}$. genişlikteki pencereler ile sağlanmıştır.

Cami zemini taş üzeri ahşap kaplama ve bugün 1sıtma şiltesi üstü halı ile döşelidir. Beden duvarları zeminden $2.40 \mathrm{~m}$. yükseklikte, pencere üstleri $0.30 \mathrm{~m}$. kademeli olarak çiniler ile donatılmıştır. Cami iç mekân duvar satıhları ile kubbe kireç harcı ile sıvalı olup, yer yer zengin kalem işi süslenmiştir. Kubbede sesin üniform bir şekilde yayılmasının sağlamak amacıyla aynı kotta karşılıklı olarak 16 adet aks-i seda küpleri yerleştirilmiştir. Küpler kubbedeki pencerelerin yaklaşık $0.50 \mathrm{~m}$. yükseklikte aynı yatay seviyede düzenli olarak sıralanmıştır.

Kubbede düzenli olarak dört sıra halinde kandil asma zincirleri yer alır.Kubbe merkezinde bir adet, ikinci seviyede 10 adet, üçüncü seviyede 17 adet ve dördüncü seviyede 20 adet toplamda 48 adet kandil asma zincirleri üzerinde yer alan kandiller ile iç mekân gece aydınlatılması sağlanmaktadır.

1915-17 y1lları arasındaki savaşlarda Rus işgalinde cami tahribat görmüş; iç mekândaki altıgen çiniler sökülüp Leningrad Müzesine götürülmüştür. Son cemaat yeri yıkılmıştır. Cami, 1915 yılındaki yangından sonra terk edilmiştir. 


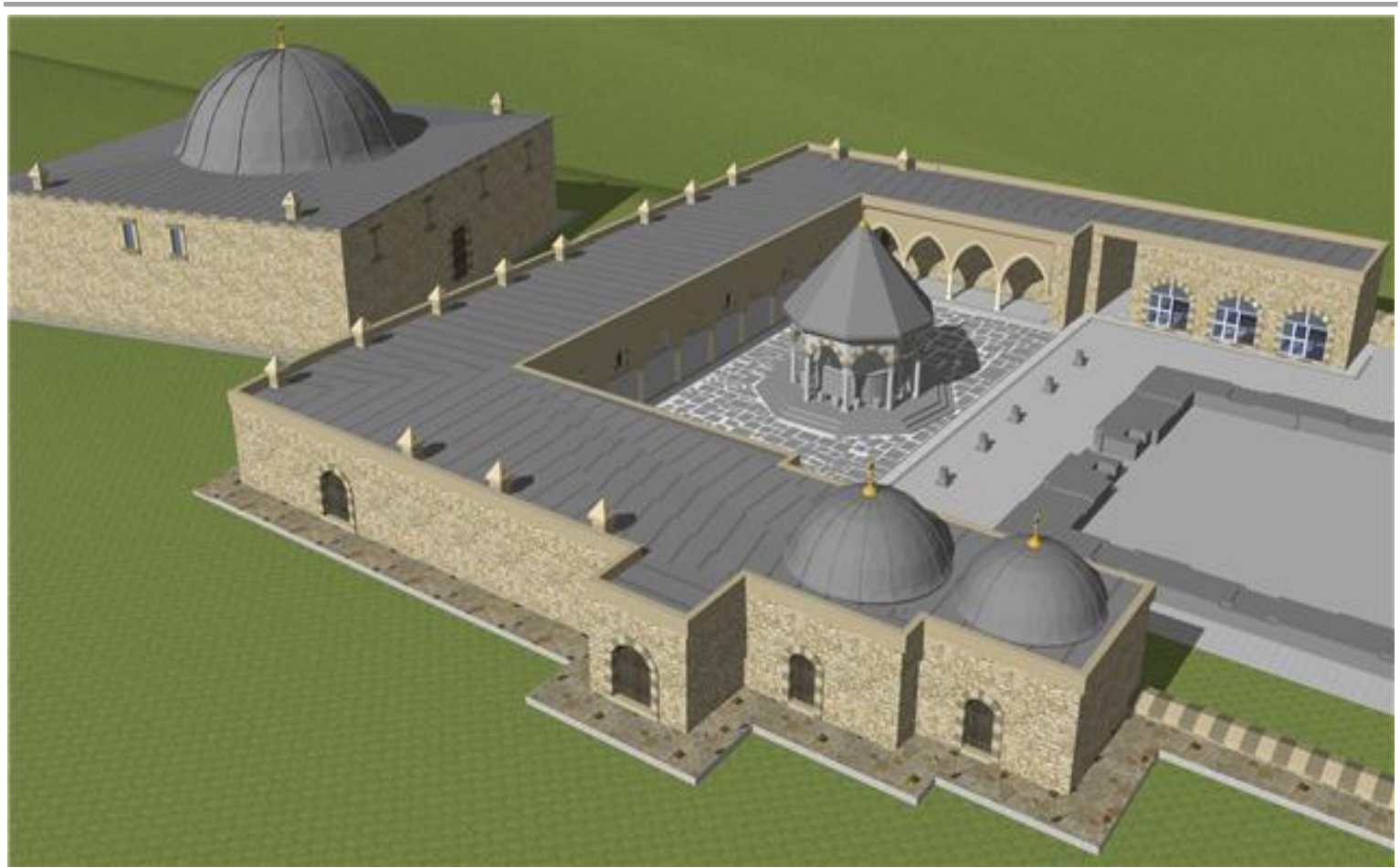

Şekil 19. Hüsrev Paşa Külliyesi Medrese Vaziyet Planı (Ş. Öztürk)

1930-40 yılları arasında depo olarak kullanılmış olup, 1960'1 yılların başında son cemaat yerinin sütun ve kemerleri yıkılmış, kubbenin kurşun kaplamaları sökülmüş olduğu eski resimlerden anlaşılmaktadır (Şekil 19-21).

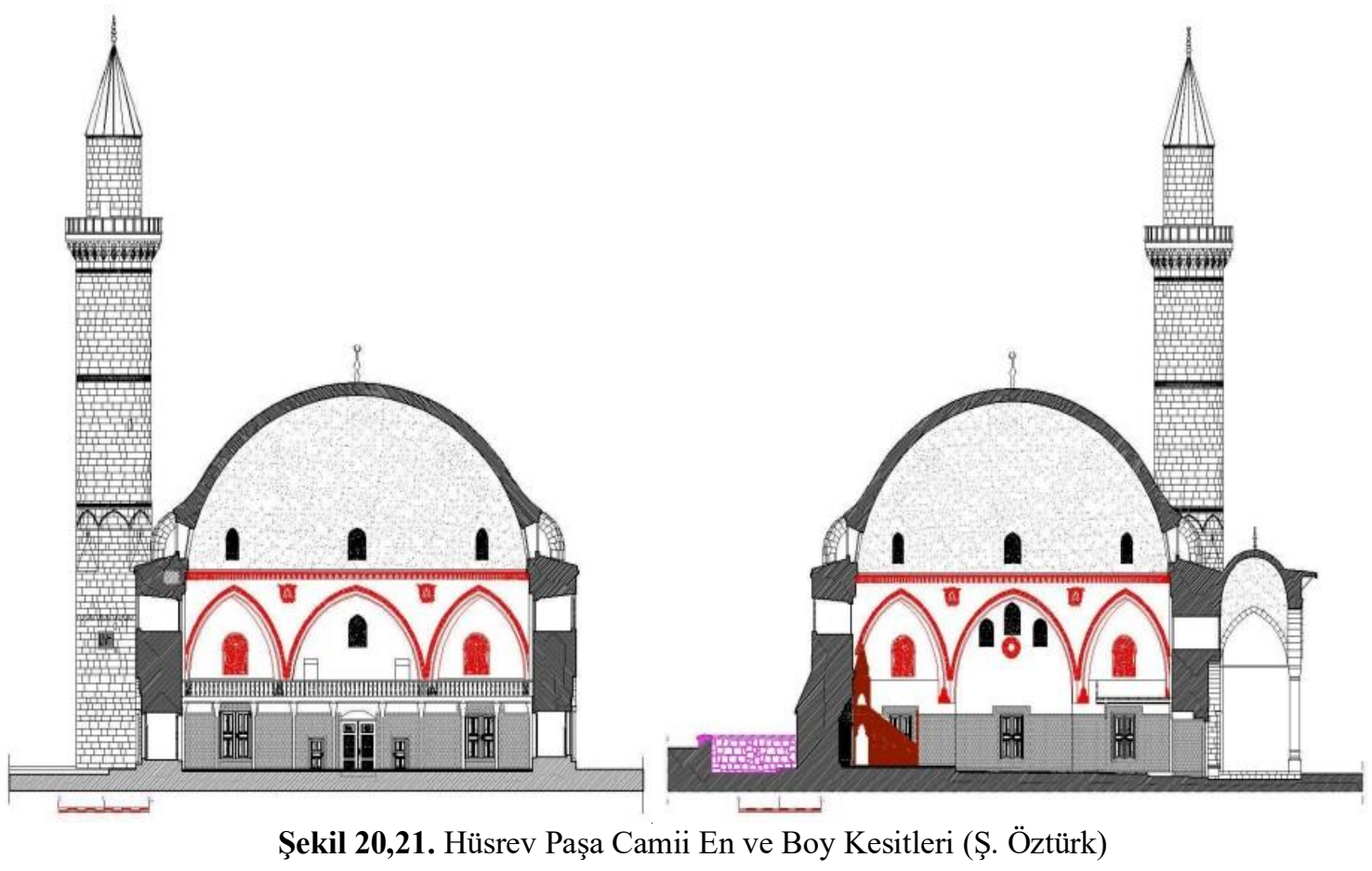

\subsection{Cepheler}

Doğu cephesi, $8.07 \mathrm{~m}$. yüksekliğinde $23.68 \mathrm{~m}$. uzunluğundadır. Cephe zemin kotu kuzeyde yaklaşık $0.20 \mathrm{~m}$. daha yüksektir. Cephede aynı mimari özelliklerde ve aynı yatay doğrultuda yer 
alan, sivri kemer niş içerisinde dikdörtgen formunda üç adet pencere yer almaktadır. Kemer pencere köşelerinde yuvarlak sütuncelere oturmaktadır. Pencere atkı taş1 yekpare üzerinde sıralı taşlar binili olarak inşa edilmiştir. Pencere alınlığ 1 bir sıra $0.26 \mathrm{~m}$. yüksekliğinde mukarnas ile donatılmıştır (Şekil 22).
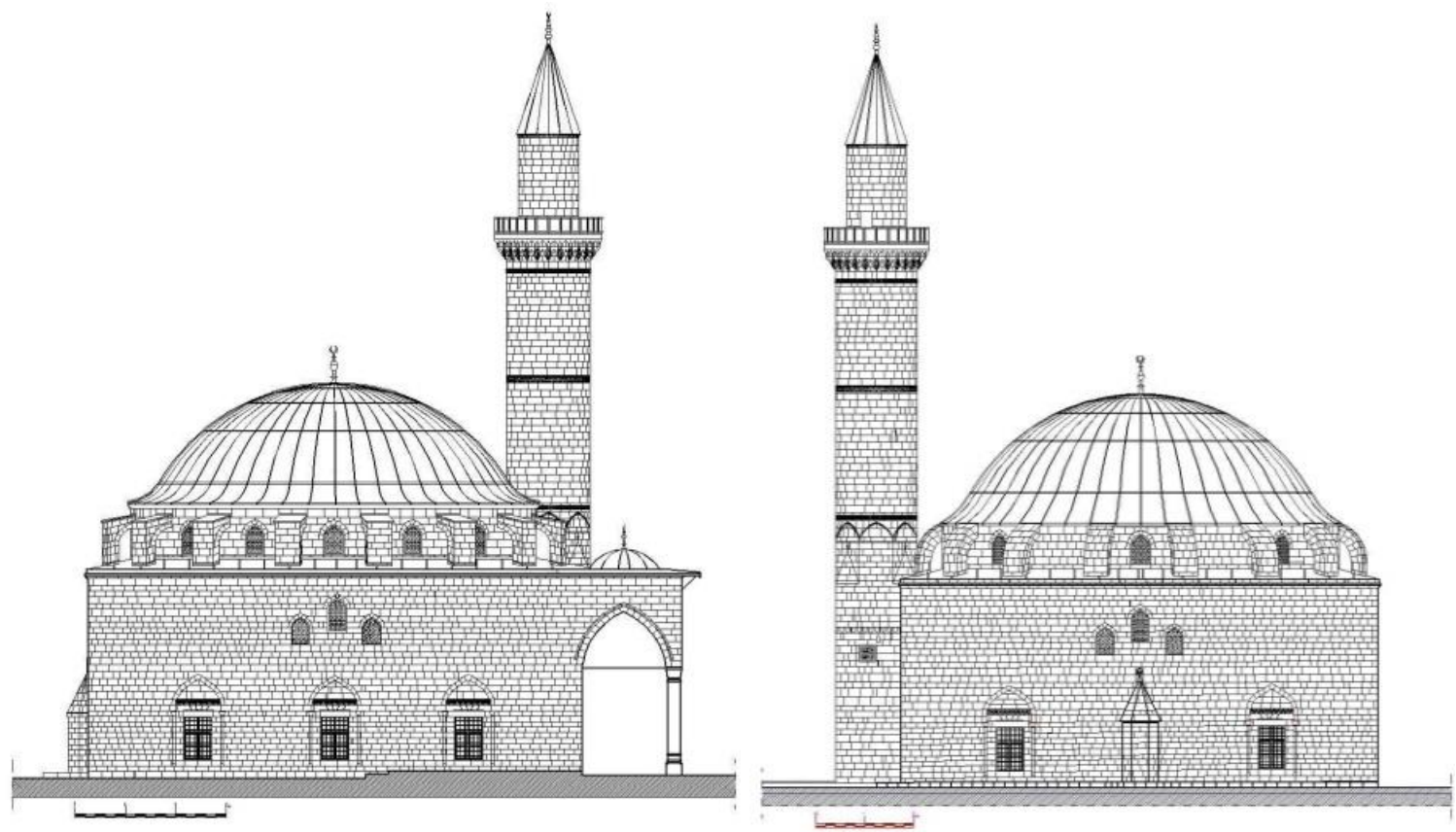

Şekil 22,23. Hüsrev Paşa Camii Doğu ve Güney Cepheleri (Ş. Öztürk)

Orta pencere üzerinde üç adet ortadaki daha yüksek aynı mimari özellikte $0.76 \times 1.34 \mathrm{~m}$. ölçülerinde sivri kemer içerisindeki pencereler fil gözü şebekeli olarak düzenlenmiştir. Cephedeki yonu taş kalınlıkları farkı dönem onarımlardan dolayı farklıdır. Cephe tek kademeli içbükey silme yardımıyla üst örtü sistemine geçiş yapmaktadır. Örtü sistemi dıştan sekizgen formundaki kasnak 1.84 m. yükselerek kubbeye geçiş yapmaktadır (Şekil 22). Sekizgen kasnak eşit aralıklı sekiz adet uçan payandalar ile desteklenmektedir. Kasnak üzerindeki sivri kemerli şebekeli pencerelerle donatılmışır. Cephenin kuzeyinde bulunan son cemaat sivri kemeri, yekpare sütunu ve kubbesi, güneyinde ise $0.74 \mathrm{~m}$. mihrap çıkıntısı yer almaktadır (Şekil 22).

Güney cephesi, $8.05 \mathrm{~m}$. yüksekliğinde $19.52 \mathrm{~m}$. uzunluğundadır. Cephenin ortasında yer alan dişa $0.74 \mathrm{~m}$. taşıntılı mihrap nişi $1.47 \mathrm{~m}$. genişlikte beş dilimli olarak $2.40 \mathrm{~m}$. yükselerek piramidal külahı bir palmet motifi ile sonuçlanmıştır. Mihrabın üst kotunda üçlü pencere dizilimi yer almaktadır (Şekil 23).

Bat1 cephesi, $8.07 \mathrm{~m}$. yüksekliğinde $23.82 \mathrm{~m}$. uzunluğundadır. Cephe pencereler, örtü sisteme geçiş elemanları, kasnak ve kubbe mimari yapısı doğu ve güney cephe mimari özelliğindedir. Cephenin kuzeyinde yer alan $3.33 \mathrm{~m}$. genişlikteki minare kaidesi, son cemaat sivri kemeri, yekpare sütunu ve kubbesi, güneyinde ise $0.74 \mathrm{~m}$. mihrap çıkıntısı yer almaktadır (Şekil 24). Kuzey cephesi, yapının diğer cephelerine göre daha hareketli bir yapıya sahiptir. Cephenin hareketlenmesinde önemli rol oynayan son cemaat bölümü, altı adet yekpare sütun yardımıyla oluşan benzer mimari özelliklere sahip iki kademeli sivri kemerlerden oluşmaktadır.

Kemerler doğu-batı ve kuzey-güney yönünde kemer üzengi seviyesinde metal gergiler ile desteklenmiştir. Kuzey cephesi duvar $0.75 \mathrm{~m}$. genişlikteki ahşap saçak yardımıyla örtü sistemine geçiş yapmaktadır. Saçak cephede 25 adet ahşap payanda ile desteklenmiştir. Son cemaat örtü sistemi beş adet benzer mimari özellikteki kubbe, ana kubbe kasnak ve eğimli uçan payandalar ile şekillenmiştir (Şekil 25). 


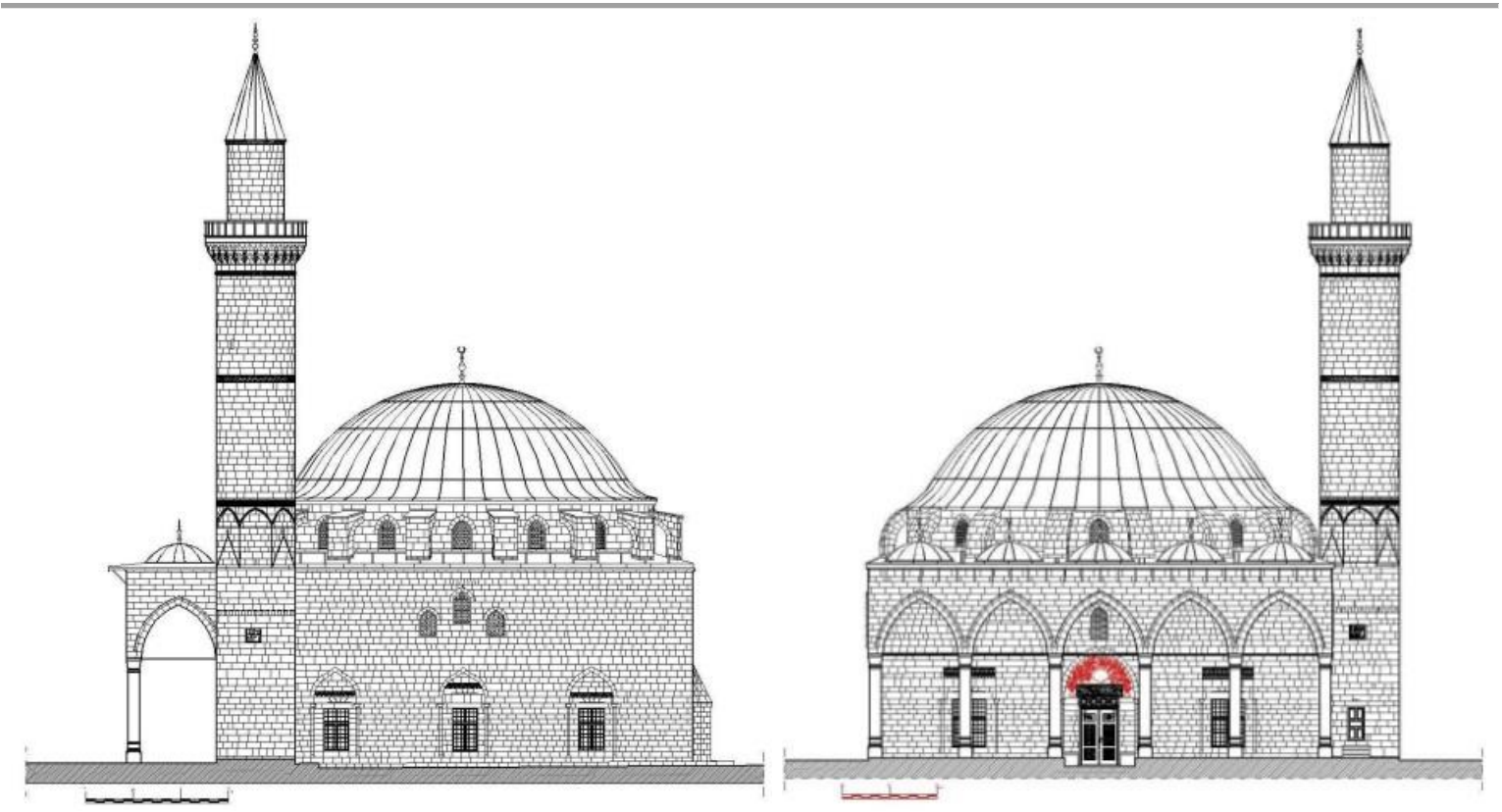

Şekil 24,25. Hüsrev Paşa Camii Batı ve Kuzey Cepheleri (Ş. Öztürk)

Oldukça hareketli olan kuzey cephesinin, ana giriş kapısı kemer nişi alınlık içerisinde yer alan $0.52 \times 1.95 \mathrm{~m}$. ölçülerindeki iki kartuş halinde oluşan kitabe yer almaktadır. Kitabeye altlık oluşturan geometrik süslemeli atkı taşı ile kitabenin her iki yanında bir kandil içerisindeki bitkisel motifler kemer alınlığında merkezinde birleşerek oluşan bir madalyon ile süslüdür.

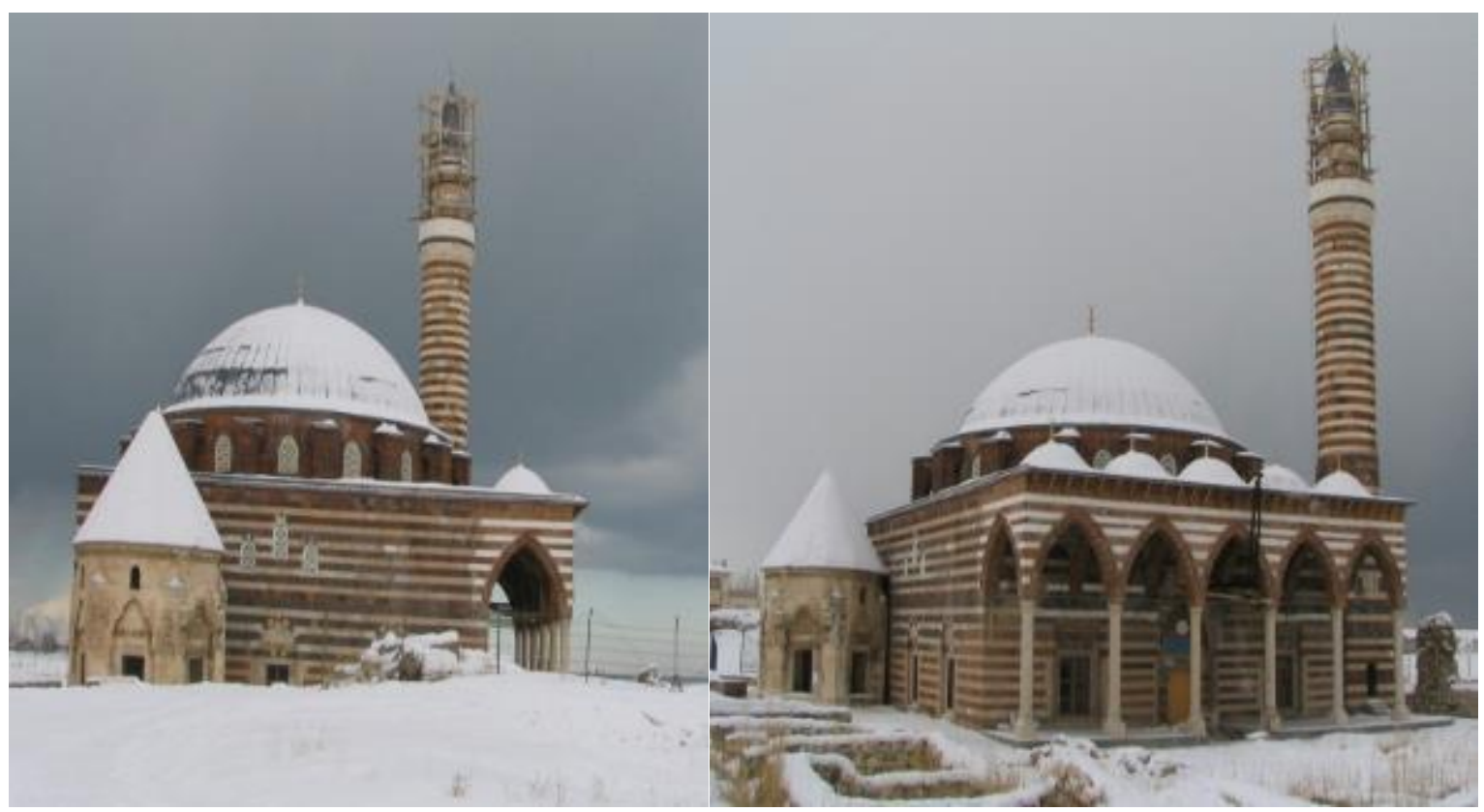

Şekil 26,27. Hüsrev Paşa Camii Doğu ve Kuzey Görünüşleri (Ş. Öztürk)

Giriş kapısı üzerinde $0.70 \times 1.42 \mathrm{~m}$. ölçülerinde bir pencere yer almaktadır. Giriş kapısının her iki yanında yer alan pencereler diğer cephelerde kullanılan pencere mimari (Şekil 26,27).

\subsection{Minare}

Caminin kuzeybatı köşesinde yer alan minare, kare bir kaide üzerinde, iki kademeli bir pabuçluk ile geçilen silindirik gövdeli ve tek şerefelidir. Şerefe ve kubbe eteğine çıkışı sağlayan merdivenin kapısı kaidenin kuzey tarafinda bulunmaktadır. 
Minarenin kürsü kısmının kuzey, batı ve güney cephelerinde satrançili yazısı ile "Billah" bezenmiştir. Peşinden gelen taş sırasından sonra kaş kemerler yüzeyi hafifçe oyulmuş olarak üç yönde bir ters bir düz olarak dolanmaktadır. Gövdeye geçişteki pahların üst kısımlarında stilize hurma dalları yer almaktadır. Pahlardan sonra sekizgen prizma şeklinde pabuç kısmı gelmektedir. Silindirik gövdenin başladığı yerde burmalı iki kuşak yer almaktadır.
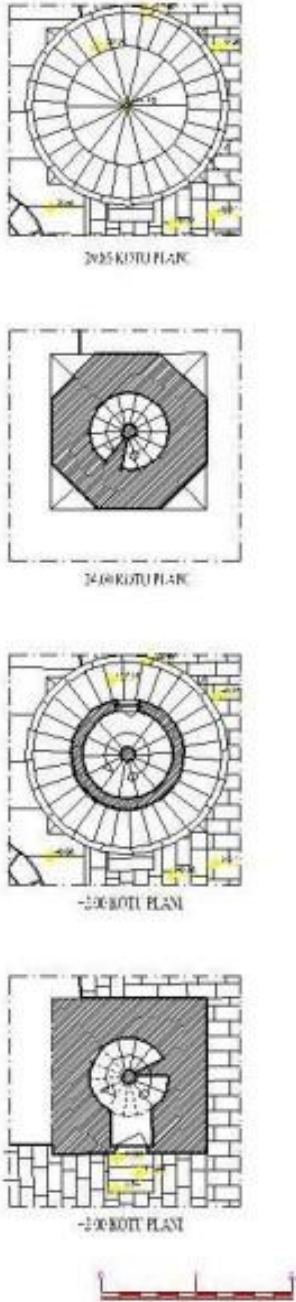
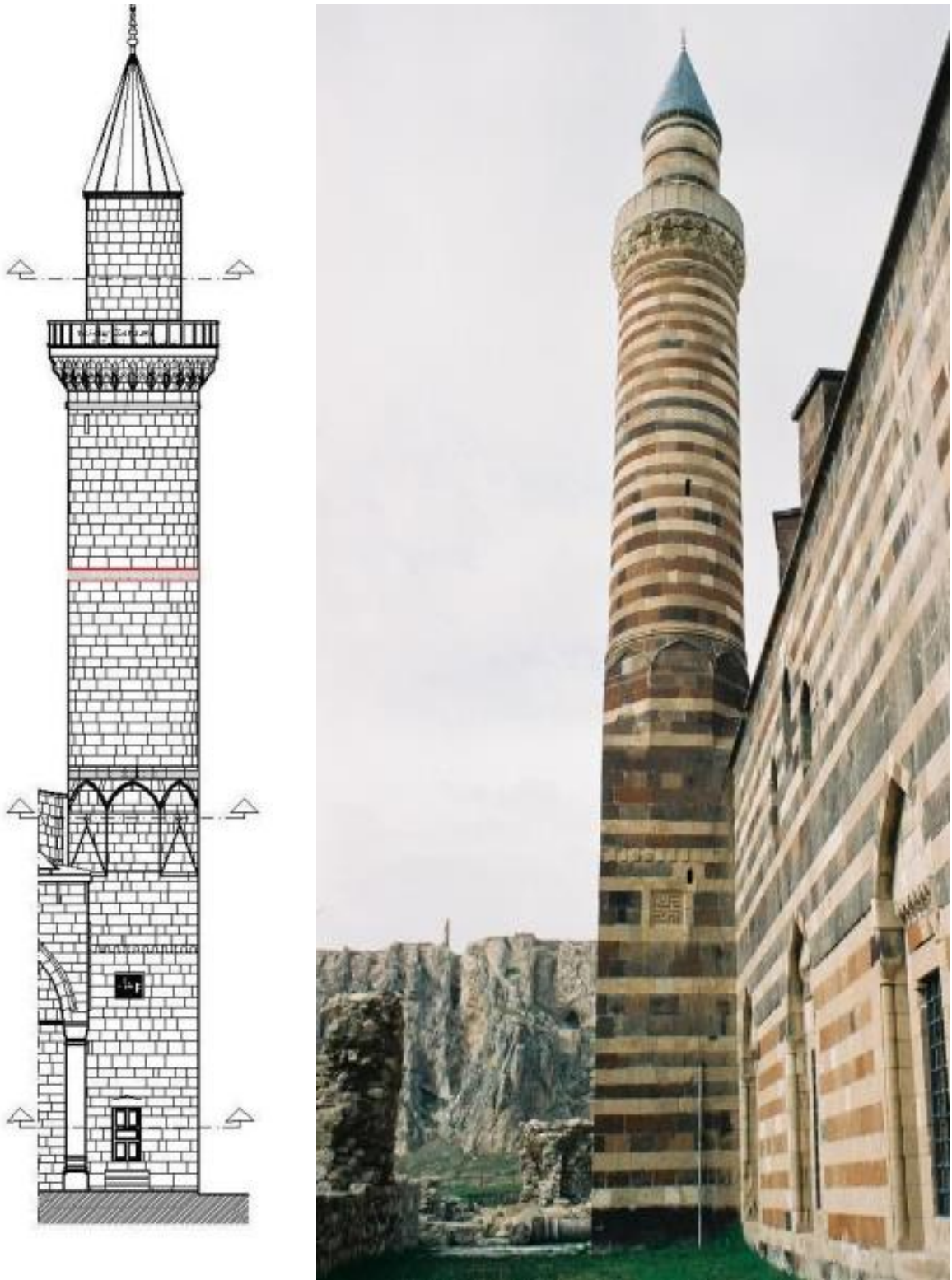

Şekil 28,29. Minare Plan, Kuzey Cephe ve Güney Görünüşü (Ş. Öztürk)

Gövdenin ortasında iki çift silmenin sınırladığı kuşağın yüzeyi birbirine geçmeli "S" motifi ile tezyin edilmiştir. Gövdenin bitiş kısmına yakın yerde çift burmalı silme bunun bir taş sıra sonrası mukarnaslı şerefe gelmektedir. Şerefe korkulukları taş levhalarla oluşturulmuştur. Silindirik bir petek ve külahla minare son bulmaktadır (Şekil 28,29). Minare girişi kuzeyden $0.74 \mathrm{~m}$. genişlikteki bir kapı ile sağlanmaktadır. Giriş kapı kotu zeminden $0.73 \mathrm{~m}$. yüksek inşa edilmiş, bu fark üç adet basamak ile aşılmaktadır. Minare kaidesinin kuzey, güney ve batı cephelerinde zeminden $4.85 \mathrm{~m}$. yükseklikte $0.68 \times 0.68 \mathrm{~m}$. ölçülerindeki pano üzerinde satrançili yazı yer almaktadır (Şekil 28,29). 
Minare kaidesi zeminden $8.25 \mathrm{~m}$. yükselerek, köşelerdeki $1.28 \mathrm{~m}$. yüksekliğindeki pahlar yardımıyla sekiz sivri kemer ile silindirik gövdeye geçiş sağlanmaktadır. Silindirik gövde $10.08 \mathrm{~m}$. yüksekliğinde olup, üzerinde farklı yüksekliklerde üç adet mazgal pencere bulunmaktadır. Minare kaidesinde bir, silindirik gövde üzerinde ise üç adet farklı yükseklik ve değişik geometrik şekillerden oluşan süslemeler yerleştirilmiştir. Minare son cemaat örtü kotunda $0.60 \mathrm{~m}$. genişliğindeki doğuya bakan bir kapı yardımıyla örtü sistemine çıkış sağlanmaktadır.

Silindirik minare çapı $3.33 \mathrm{~m}$., duvar kalınlığ $10.80 \mathrm{~m}$., basamak genişliği $0.70 \mathrm{~m}$., sütun çapı ise $0.30 \mathrm{~m}$.dir. Silindirik minare $0.90 \mathrm{~m}$. her iki yandan makarnaslı süslemeler yardımıyla genişleyerek şerefe bölümüne geçiş sağlanmaktadır. Şerefe korkuluk kalınlığ $10.15 \mathrm{~m}$. yüksekliği ise $1.05 \mathrm{~m}$. dir. Şerefe bölümünden güneye bakan $0.60 \mathrm{~m}$. genișliğinde bir kapı yerleștirilmiștir. Şerefeden sonra petek bölümü $4.28 \mathrm{~m}$. daha yükselerek mukarnaslı bir süsleme bandı ile külah kısmına geçiş yapmaktadır. Minare zeminden alem bölümüne kadar yüksekliği 31.87 m.dir (Şekil 28,29).

\section{4. Örtü Sistemi}

Cami örtü sistemi son cemaat bölümü ve ana kubbeden oluşmakta olup, 19.52×24.56 ölçülerinde dikdörtgen planlıdır. Ana kubbe dıştan $16.46 \mathrm{~m}$. çapında, yuvarlak kasnak üzerine oturmuştur.

Kubbenin üzerinde yer aldığı kasnağın çevresinde 16 adet 1.00 kalınlığında eğimli uçan payanda ile desteklenmiştir. Örtü sistemi tamamıyla kurşun malzeme ile kaplanmıştır. Örtü sistem, kuzeyde $0.75 \mathrm{~m}$. diğer cephelerde $0.15 \mathrm{~m}$. saçakla çevrelenmiştir (Şekil 30-31).

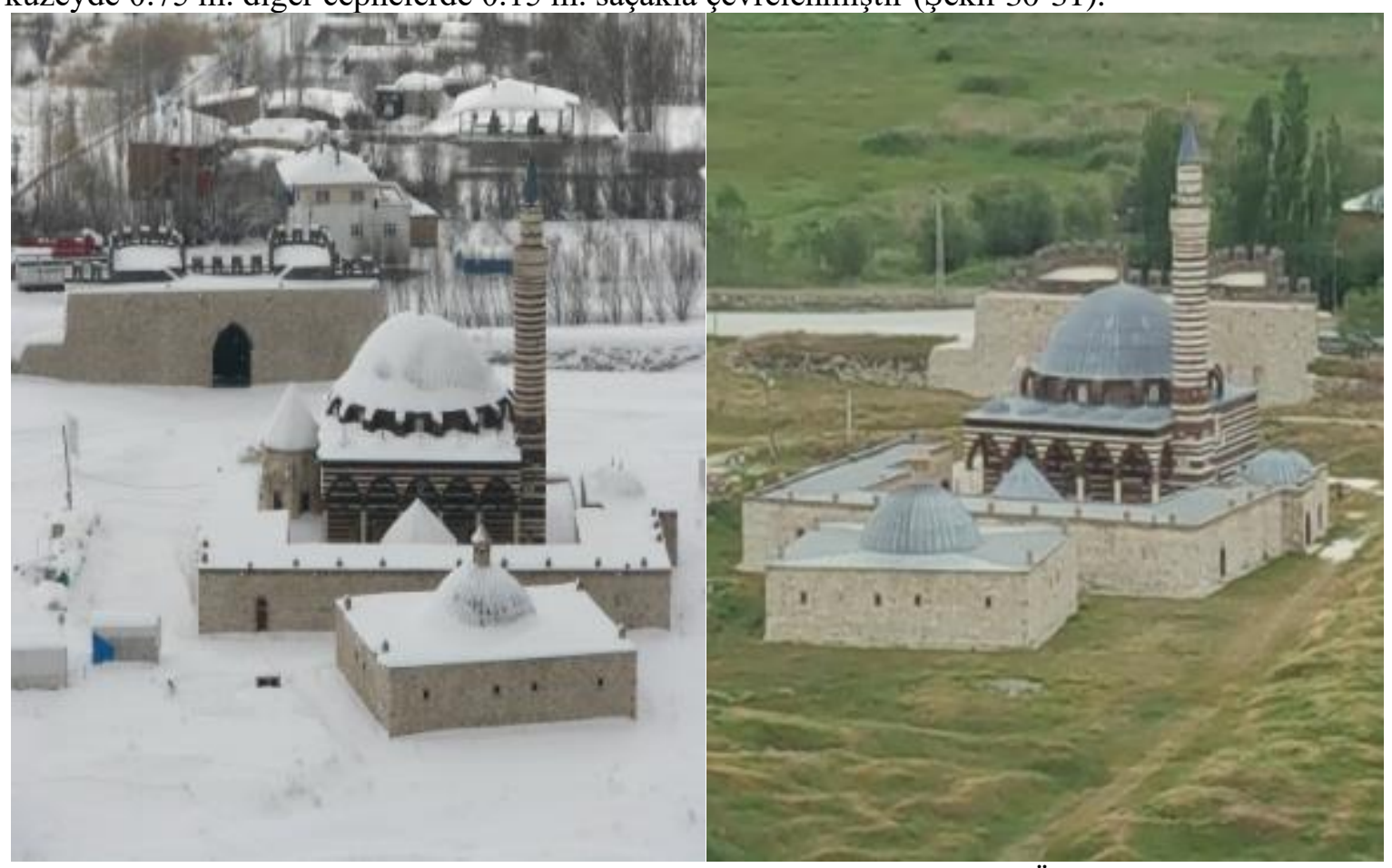

Şekil 30,31. Hüsrev Paşa Külliyesi Vaziyet Görünüşleri (Ş. Öztürk)

\subsection{Malzeme ve Yapım Teknikleri}

Hüsrev Paşa Külliyesi’nin önemli bir bölümünü oluşturan cami inşasında yapım malzeme olarak; yonu taş, tuğla, moloz taş, ahşap, kurşun, çini, yekpare sütun, altın varak ve metal donatı malzeme kullanılmıştır. Bağlayıcı malzeme olarak yapıda kireç harcı kullanılmıştır. Yapıda kullanılan taş cinsi ise yöresel bazalt ve kalkerdir (Şekil 32,35). 

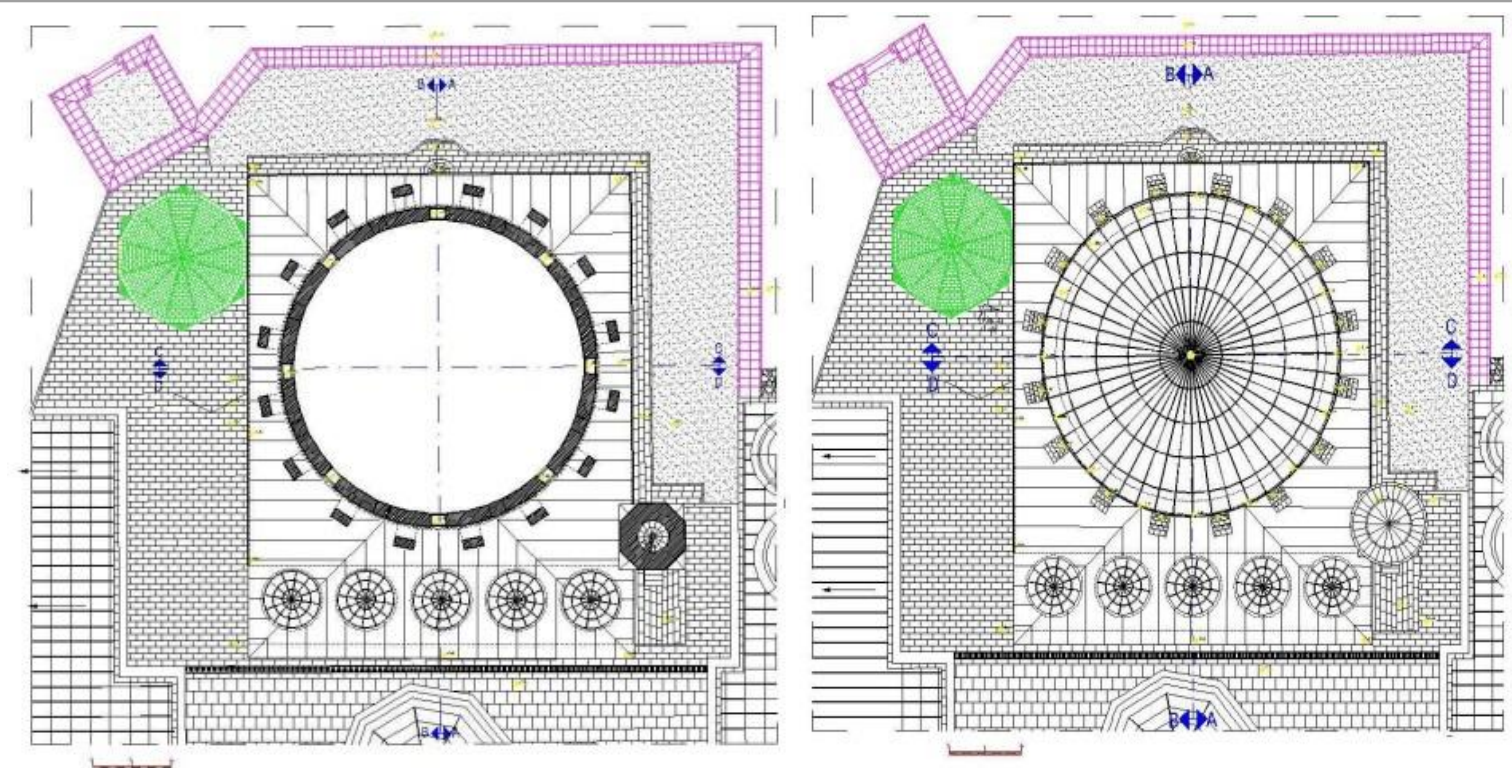

Şekil 32,33. Hüsrev Paşa Camii Kubbe Kasnak ve Örtü Planları (Ş. Öztürk)

Yonu taş; pencere, kapı, söve, uçan payanda, beden duvarı, minare, mihrap, saçak silmesi, kemer, zemin döşeme kaplamasında kullanılmıștır. Beden duvarlarında kullanılan yonu taşı ardaşık iki renk halinde, tuğla; ana kubbe, ana kubbe tromplarında ve son cemaat kubbe pandandiflerinde, moloz taş; yapının beden ve minare duvar iç dolgu malzemesi olarak kullanılmıştır (Şekil 32,35).

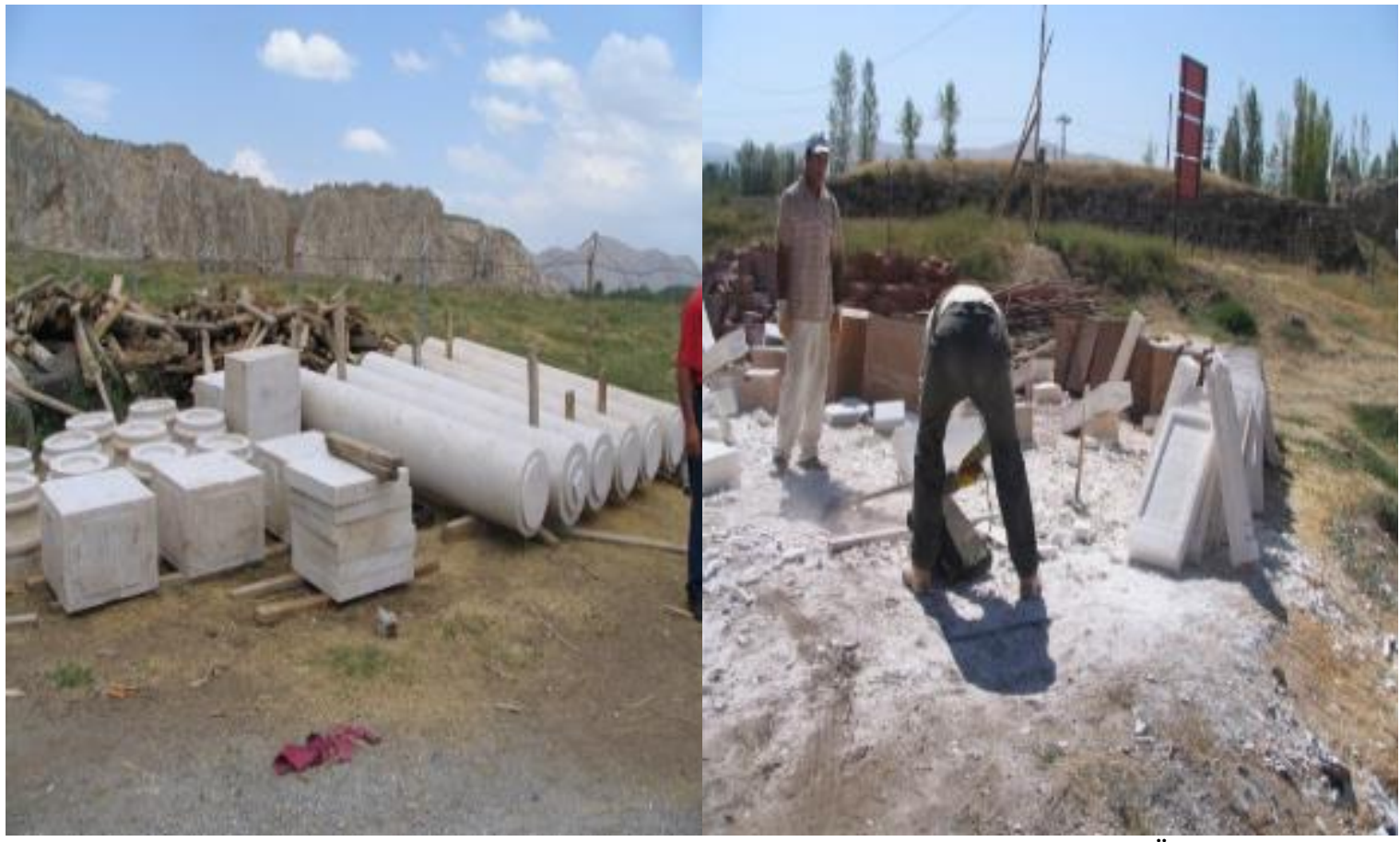

Şekil 34,35. Hüsrev Paşa Külliyesi Cami Onarım Malzeme Görünüşüleri (Ş. Öztürk)

Ahşap; yapının tüm kapı ve pencere kanat ve kasa doğramalarında, mahfil katı yapımında, minber, kürsü ve kitaplık yapımında kullanılmıştır. Kurşun kaplama; Cami üst örtü sisteminde keçe destekli 1.5 mm. kalınlıkta kurșun kaplama kullanılmıștır. Çini; caminin iç mekanında, Yekpare sütun; Son cemaat bölümünde, Altın varak; cami giriş kapı kitabe bölümü ile mihrap süslemesinde, Metal donat1; Son cemaat bölümü kemer gergi çubuklarında, tavan kandil zincirleri ve kapıpencere aksesuvarlarında kullanılmıştır (Şekil 32,35). 


\section{ONARIM ÇALIŞMALARI}

Hüsrev Paşa Külliyesi'nin merkezinde yer alan camide, farklı dönemlerde dört kez onarım çalışması yapılmıştır. Bunlar;

1- 1967 Yı1ı Diyarbakır Vakıflar Bölge Müdürlüğü Onarım Çalışmaları

2- 1996-2002 Yıllarıarası Van Müze Başkanlığı Kazı ve Onarım Çalışmaları

3- 2007-08 Yıllarıarası Bitlis Vakıflar Bölge Müdürlüğü Onarım Çalışmaları.

4- 2012-13 Yıllarıarası Bitlis Vakıflar Bölge Müdürlüğü Onarım Çalışmaları.

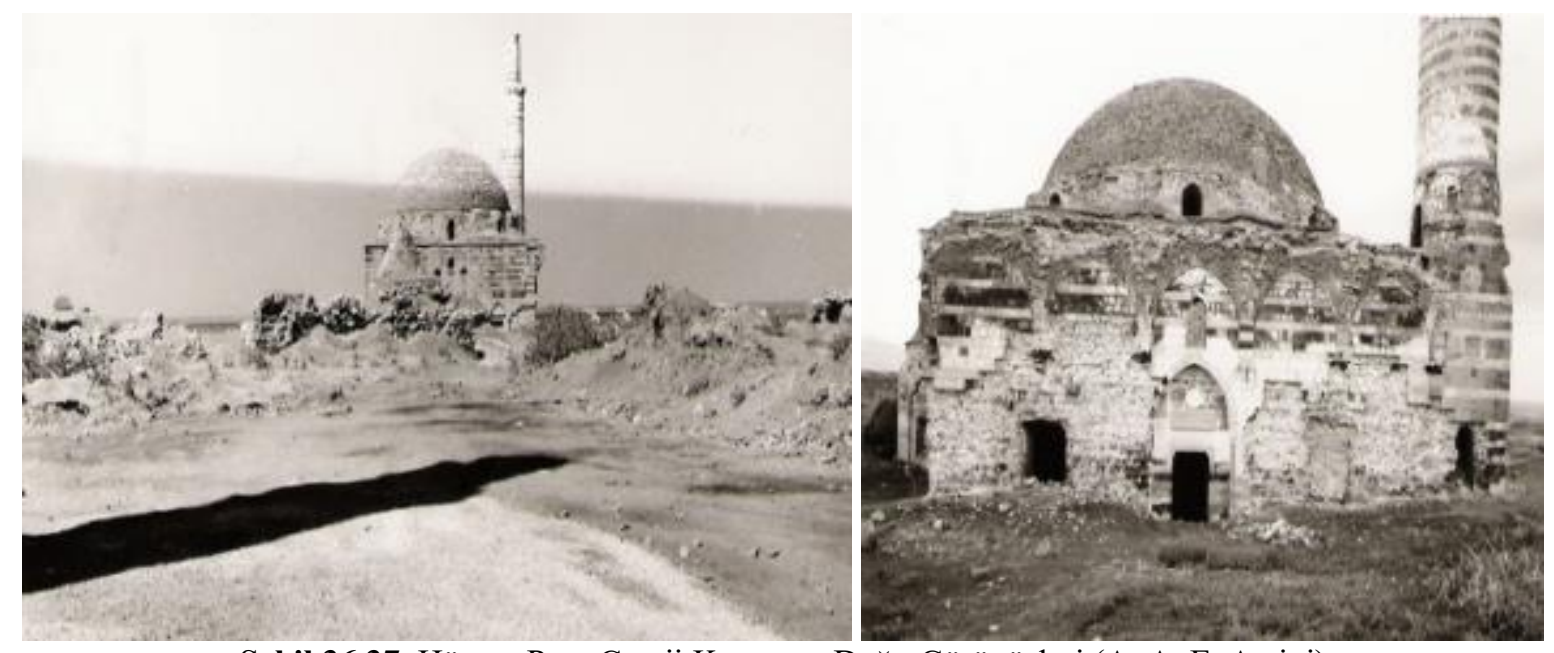

Şekil 36,37. Hüsrev Paşa Camii Kuzey ve Doğu Görünüşleri (A. A. E. Arşivi)

\section{1- 1967 Yılı Diyarbakır Vakıflar Bölge Müdürlüğü Onarım Çalışmaları;}

1967 yıllında yapılan küçük ölçekli restorasyon çalışmalarının bilgilerini, yayımlanan makalelerden öğreniyoruz. Bu çalışmaların Bitlis ve Diyarbakır Vakıflar Bölge Müdürlüğü tarafından belgeleri bulunmadığı için, birinci kaynak olarak bilimsel makaleler temel alınmıştır (Uluçam, 1994: 13).

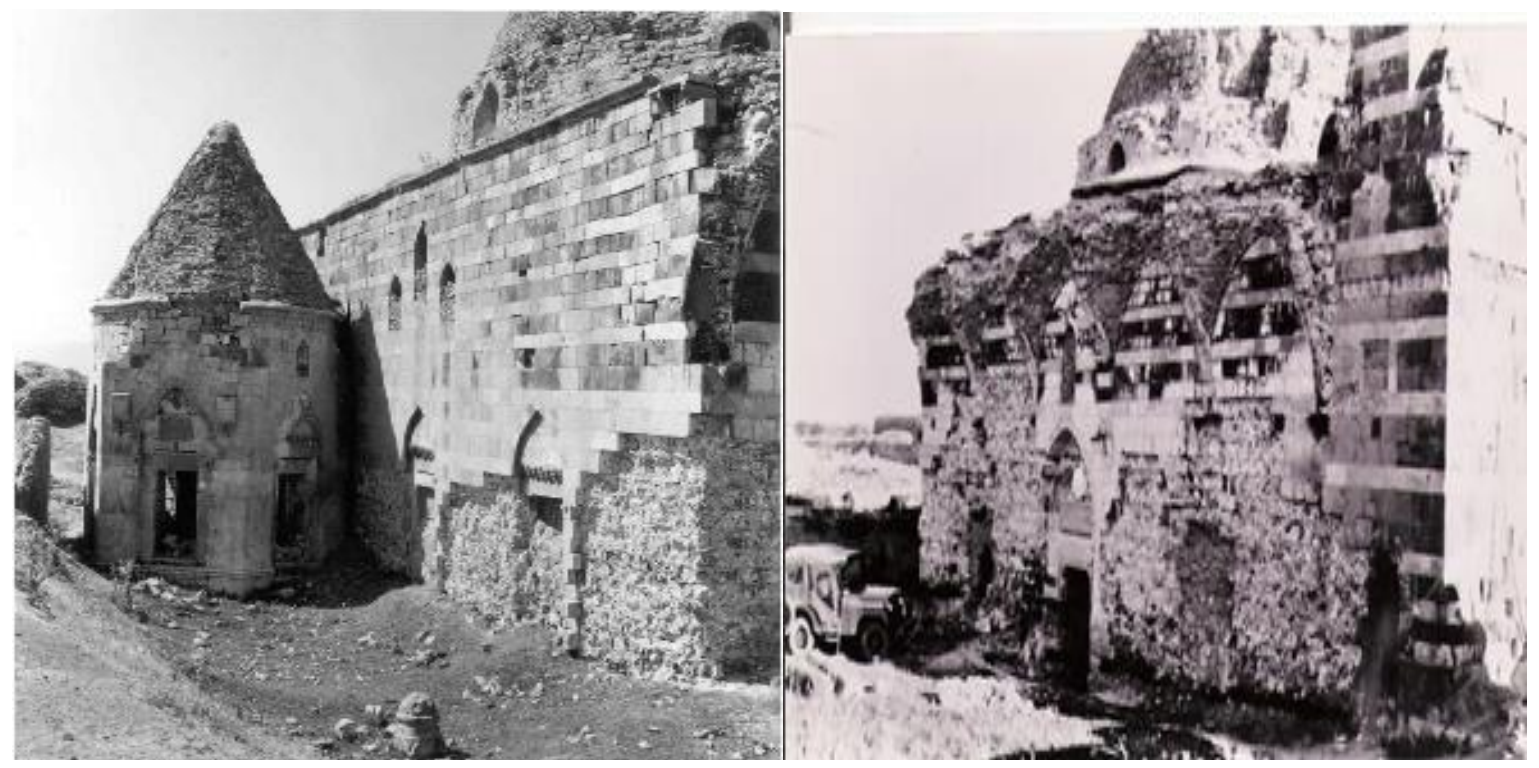

Şekil 38,39. Hüsrev Paşa Camii Kuzey ve Doğu Görünüşleri (A. A. E. Arşivi)

1960 y1lında caminin kubbesi çatlayıp, son cemaat yeri y1kılınca, 1967'den itibaren değişik projelerle Vakıflar Genel Müdürlüğü’nce onarımlara başlanmış, ancak yarım kalmıştır. Yapılan bu 
çalışmalarda, yıkılan minare külahı tamamlanmış, duvarlarda bozulan ve düşen taşların yerine yenileri konulmuş ve taşlar arasında özelliğini yitiren kireç harcı yerine, çimento kullanılarak sağlamlaştırılmıştır (Uluçam-Kavaklı, 1998: 684).

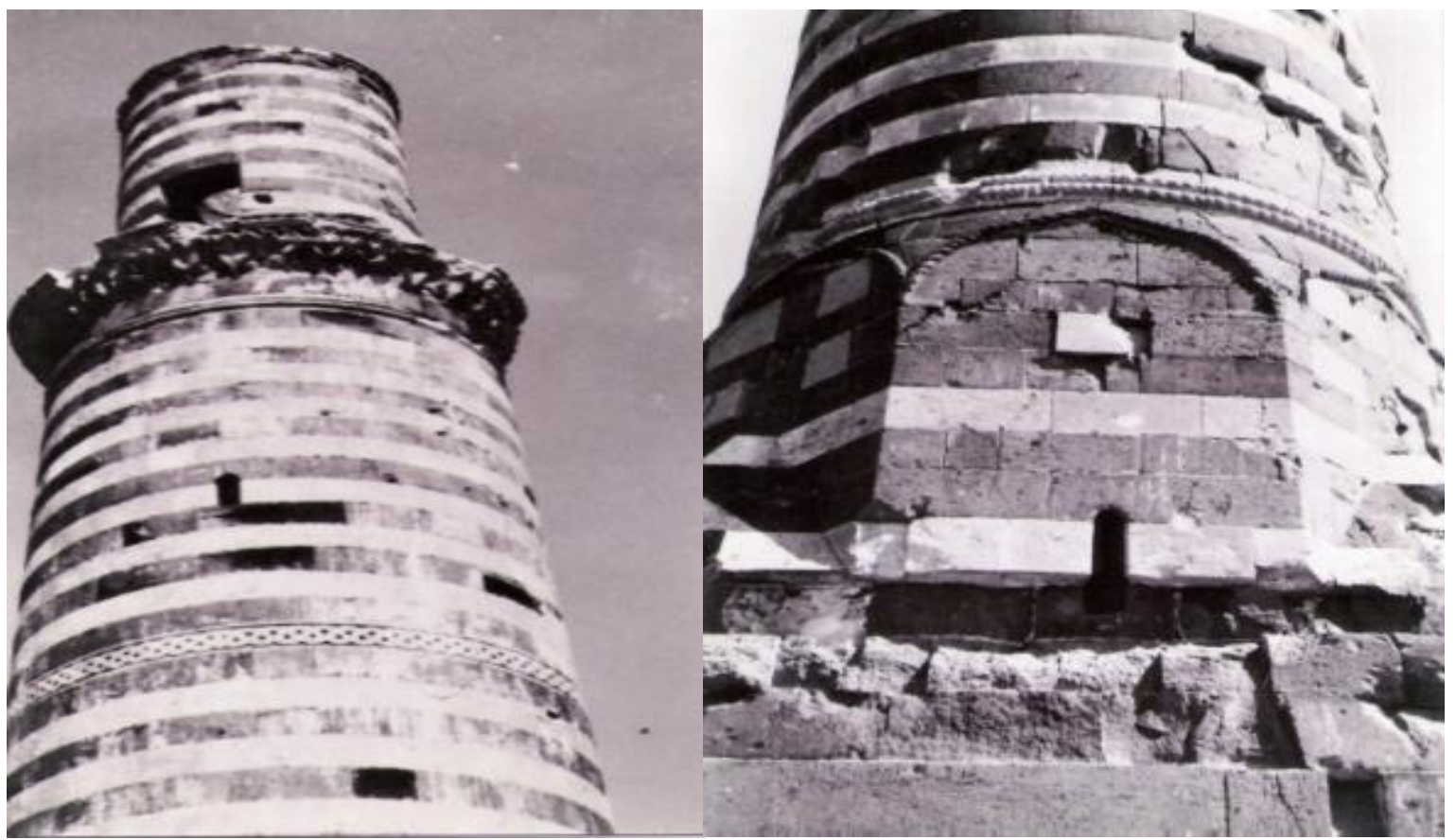

Şekil 40,41. Hüsrev Paşa Camii Minare Kaide ve Gövde Görünüşleri (A. A. E. Arşivi)

Duvarlardaki eksik taşlar, cami duvarlarında kullanılan taşlara uygun olarak yine Ahlat'taki taş ocağı yataklardan çıkarılarak tamamlanmıştır. Eksik olan pencere doğramaları ve cami kapısı takılmış, kubbe, yuvarlak bir kasnak ile desteklenmiş ve kasnağın çevresinde yıkılan 16 adet payandanın taşları, yeniden onarılmıştır (Öztürk, 1996: 16), (Şekil 36-41).

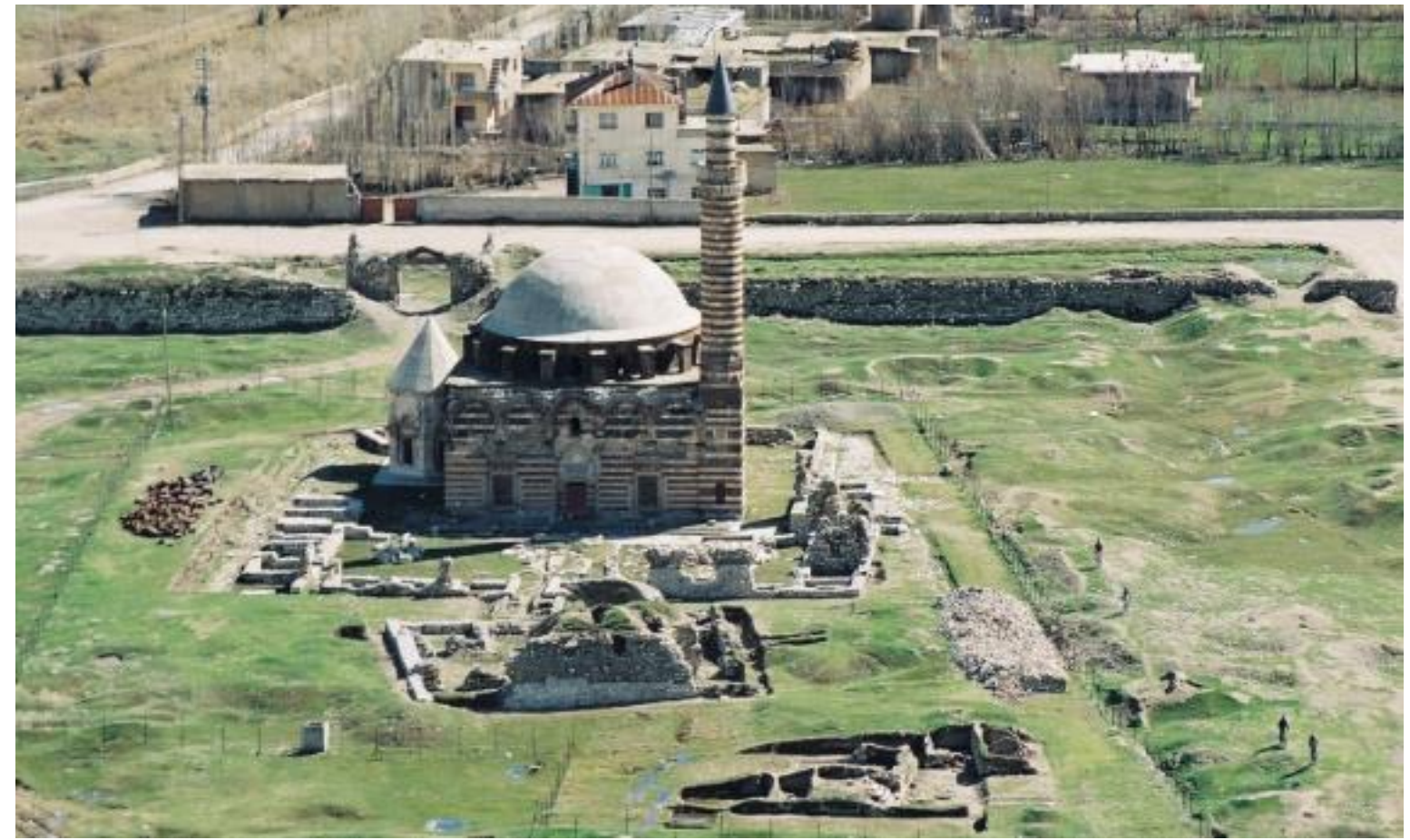

Şekil 42. Hüsrev Paşa Külliyesi Kazı ve Temizlik Sonrası Genel Görünüşü (Ş. Öztürk) 


\section{2- 1996-2002 Yıllarıarası Van Müze Başkanlığı̆ Kazı ve Onarım Çalışmaları;}

Van Müze Müdürlüğü Başkanlığı'nda ve Yüzüncü Yı1 Üniversitesi öğretim elemanlarının bilimsel ve teknik sorumluluğunda 1996 yılında başlayan "Hüsrev Paşa Külliyesi Kazı ve Restorasyon Çalışmaları” 2002 yılına kadar devam etmiştir (Şekil 42,43).

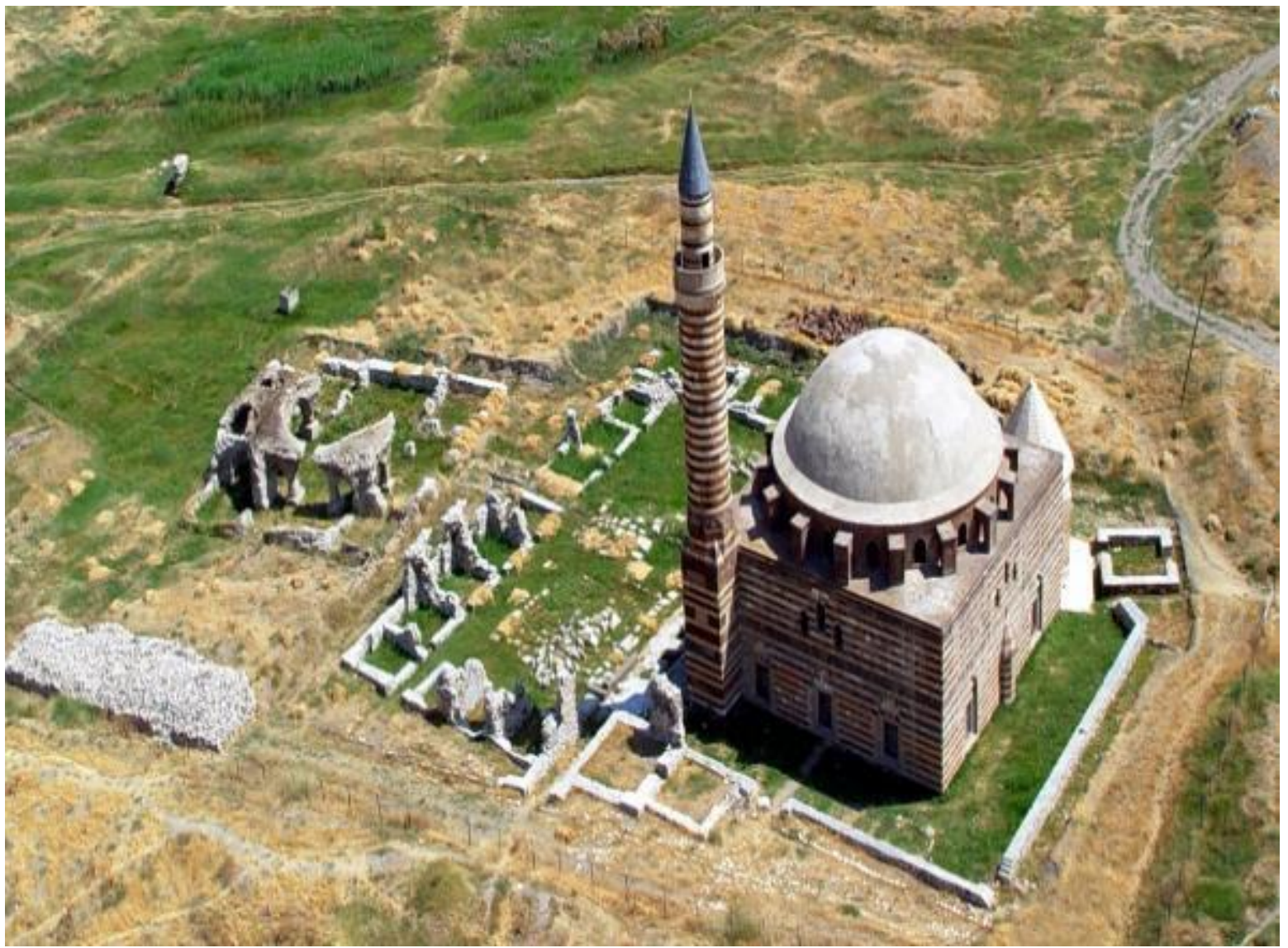

Şekil 43. Hüsrev Paşa Külliyesi Kazı ve Temizlik Sonrası Genel Görünüşü (Ş. Öztürk)

Bunlar; temizlik çalışmaları, sondaj çalışması, belgeleme işlemi, külliyenin içindeki suyun 1slahı, arkeolojik kazı çalışmaları, çevre düzenlemesi, kazı alanından çıkan malzemenin tasnifi, rölöve çalışması, konservasyon çalışması ve laboratuar çalışmasıdır.

\section{3-2007-08 Yıllarıarası Bitlis Vakıflar Bölge Müdürlüğü Onarım Çalıșmaları;}

Cami, temizlik ve bilimsel kazı çalışmaları 2002 yılında tamamlanarak yapıya ait tüm mimari veriler elde edilmiştir. Bu mimari veriler sonucunda yapının rölövesi çıkarılmış, restitüsyon ve restorasyon projeleri hazırlanarak bunlar Van Kültür Varlıkları Bölge Kurul Müdürlüğü tarafından onaylanmıştır. Onaylanan uygulama projeleri doğrultusunda Vakıflar Bitlis Bölge Müdürlüğü tarafından 2007 yılında yapım ihalesi yapılmıştır. Caminin onarım çalışmaları Vakıflar Bölge Müdürlügü̈, yüklenici firmanın teknik kontrol elemanları ve proje müellifinin ortak denetiminde yapılarak, 2008 yılında tamamlanmıştır. Yüklenici firma iş programında yer alan çalışma esnasında yapının çevre ile ilişkisini kesmek ve iş güvenliğini sağlamak amacıyla geçiçi koruma çit ile çevreleyerek gerekli can ve mal güvenlik önlemlerini almıştır.

Eski Van Şehri yaklaşık son yüz yıllık dönemde doğanın olumsuz etkisi, şehir yer altı su kanallarının tahrip olması ve zaman zaman Van Gölü su kotunun yükselmesi sonucunda taban su kotu sürekli yükselmiştir. Bu olumsuz nedenlerden dolayı, yapıyı korumak amacıyla beden 
duvarlarında yapılan araştırma kazısı yapılmıştır. Kazı sonrasında uygulama projesindeki esaslara bağlı kalarak, kapalı drenaj sistemi yapılarak, biriken yeraltı suları özel kanallar ile daha düşük kot olan batı yönüne doğru drene edilmiştir (Şekil 44-46).
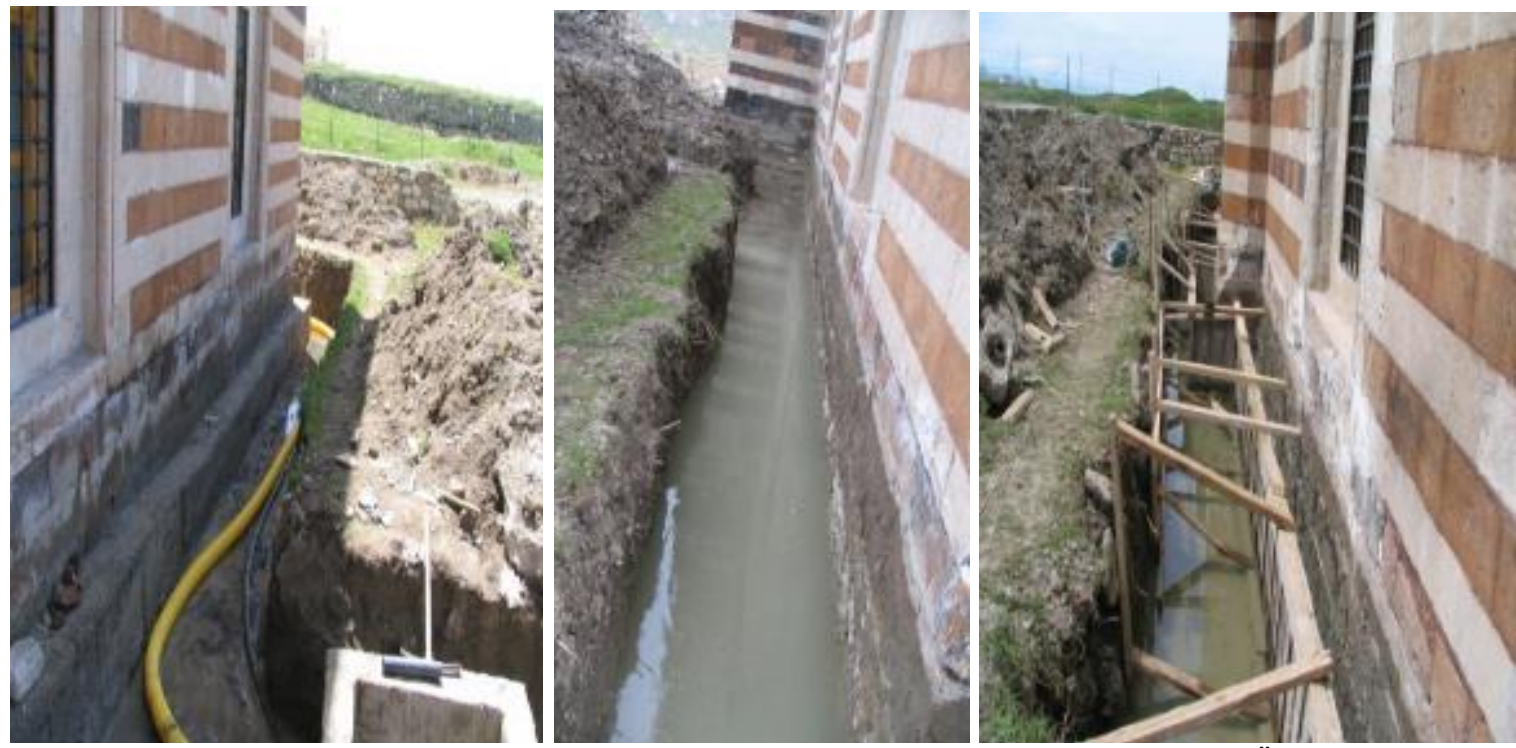

Şekil 44-46. Hüsrev Paşa Camii Kapalı Drenaj Sistemi Genel Görünüşleri (Ş. Öztürk)

Tamamıyla yıkık bir konumda olan son cemaat bölümü, hazırlanan ve onaylı restorasyon projesine uygun bir şekilde yapılarak tamamlanmıştır. Harimin bölümü üst kat ahşap doğramalı mahfil bölümü 20 adet ahşap dikme üzerinde $3.58 \mathrm{~m}$. genişliğinde yeniden aslına uygun bir şekilde inşa edilmiştir. Harimin iç kısmına yerleştirilen ahşap iskele yardımıyla kubbe bölümünden başlayarak tüm duvarların yüzey temizlik, bakım ve onarımları büyük bir titizlikle yapılmıştır.

Kubbede oluşan çatlak ve yarıklarda onarımı enjeksiyon ve dikiş yapılarak sağlamlaştırılmıştır İç mekân duvar ve kubbe satıhları özel olarak hazırlanan kireç harçlı sıva çalışması ve özgün sıva üzeri kalem işi süsleme bezemelerinin tamamlama ve özgün bölümlerini konservasyon çalışmaları konusunda uzman konservatöreler tarafından yapılmıştır. Kubbe kasnağında yer alan 16 adet ve beden duvarlarında bulanan 10 adet sivri kemerli aydınlatma iç alçı ve diş taş pencereli şebekeler yeniden inşa edilmiştir (Şekil 47-49).
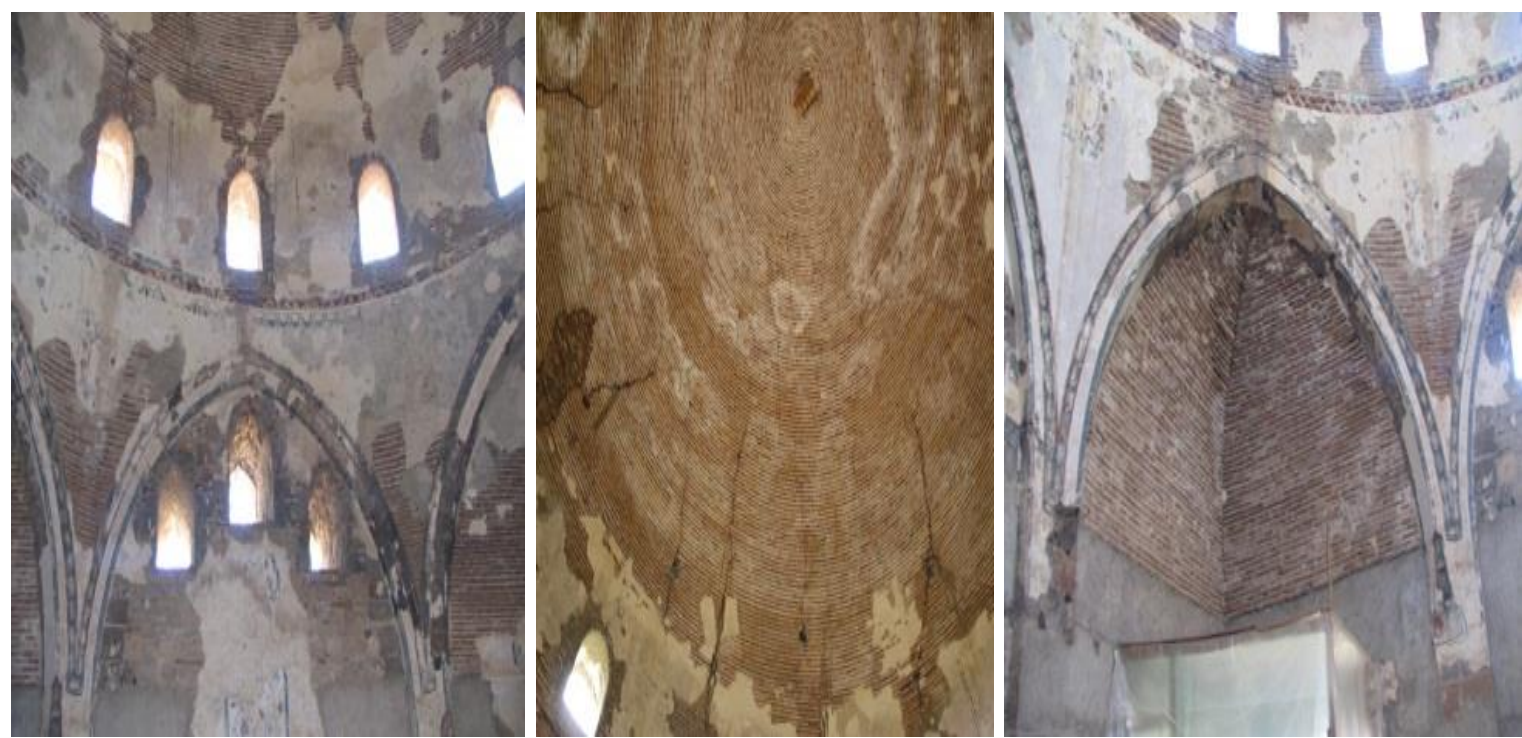

Şekil 47-49. Hüsrev Paşa Camii Kubbe ve Tromp Genel Görünüşleri (Ş. Öztürk)

Turkish Studies, 15(2) 
Harim mekânını tüm beden duvarları zeminden $2.37 \mathrm{~m}$. yüksekliğe kadar pencere üzerlerinde $0.30 \mathrm{~m}$. kademe olacak şekilde özgün çini örneklerinde oluşan çini kaplamas1 tamamlanmıştır. Caminin tüm pencere doğramaları içten çift kanatlı, dıştan ahşap kayıtlı olarak ve taban zemin ahşap rabıta olarak yapılmıştır. Giriş kapısı, minber, kürsü ve kitaplık ceviz doğramalı Kahramanmaraşlı ahşap ustalar tarafından geleneksel bezeme motifli olarak hazırlanmıştır (Şekil $50-54)$.

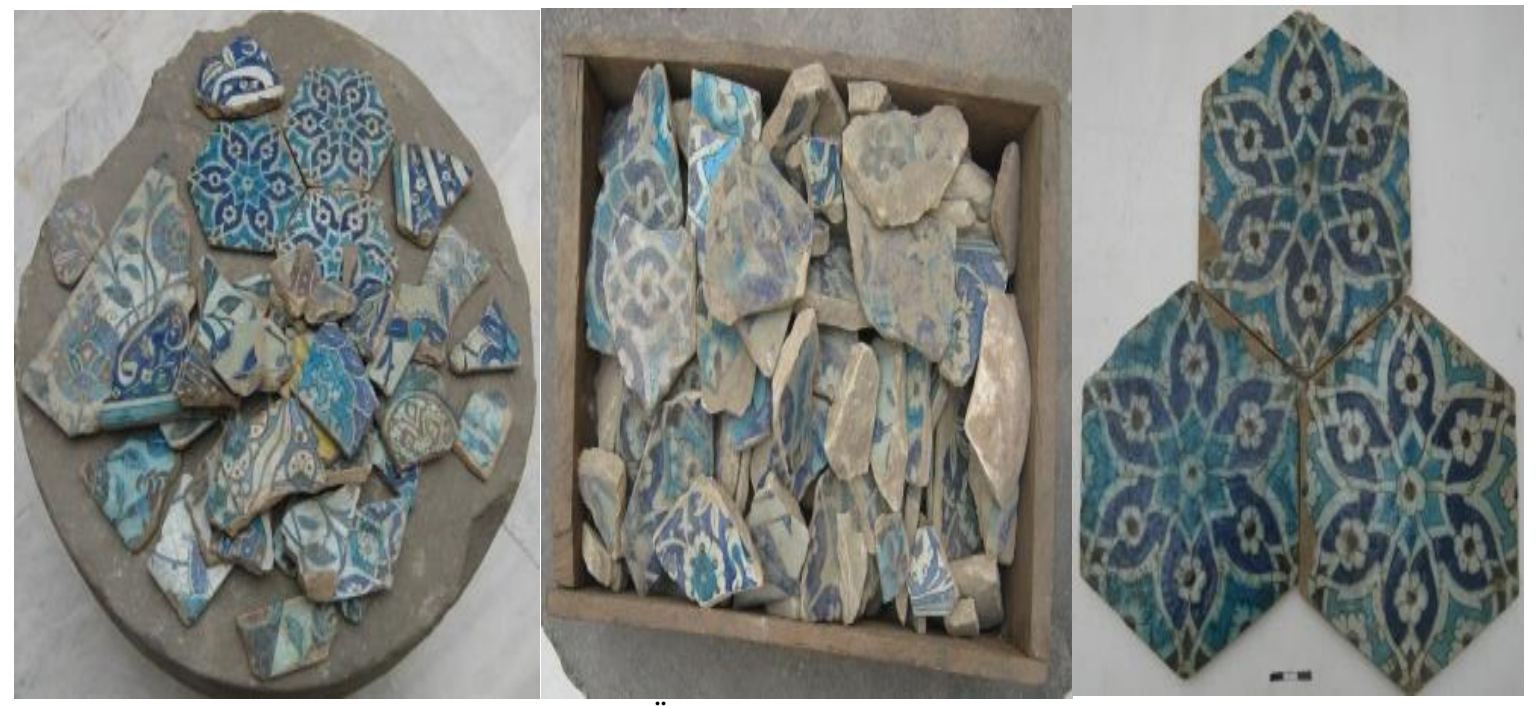

Şekil 50-52. Hüsrev Paşa Camii Özgün Çini Genel Görünüşleri (Van Müze Arşivi)

Güney bedeninin ortasında yer alan dekoratif süslemeli mihrap içten ve diştan oldukça tahrip olmuş bir konumda idi. Mihrabın daha önceki müdahalelerde alçı ile kısmen onarılan ve hatalı uygulamalar, raspa edilerek gerekli temizlik çalışmaları yapılmıştır. Yapılan temizlik çalışmalarında mihrap üç dilimli kemerin üst alınlık yüzeyinde her iki yanında kare formunda üste simetrik "Satrançili" ile alt kısımda ise yuvarlak formunda "Mühr-i Süleyman" süsleme motifleri ortaya çıkarılmıştır.

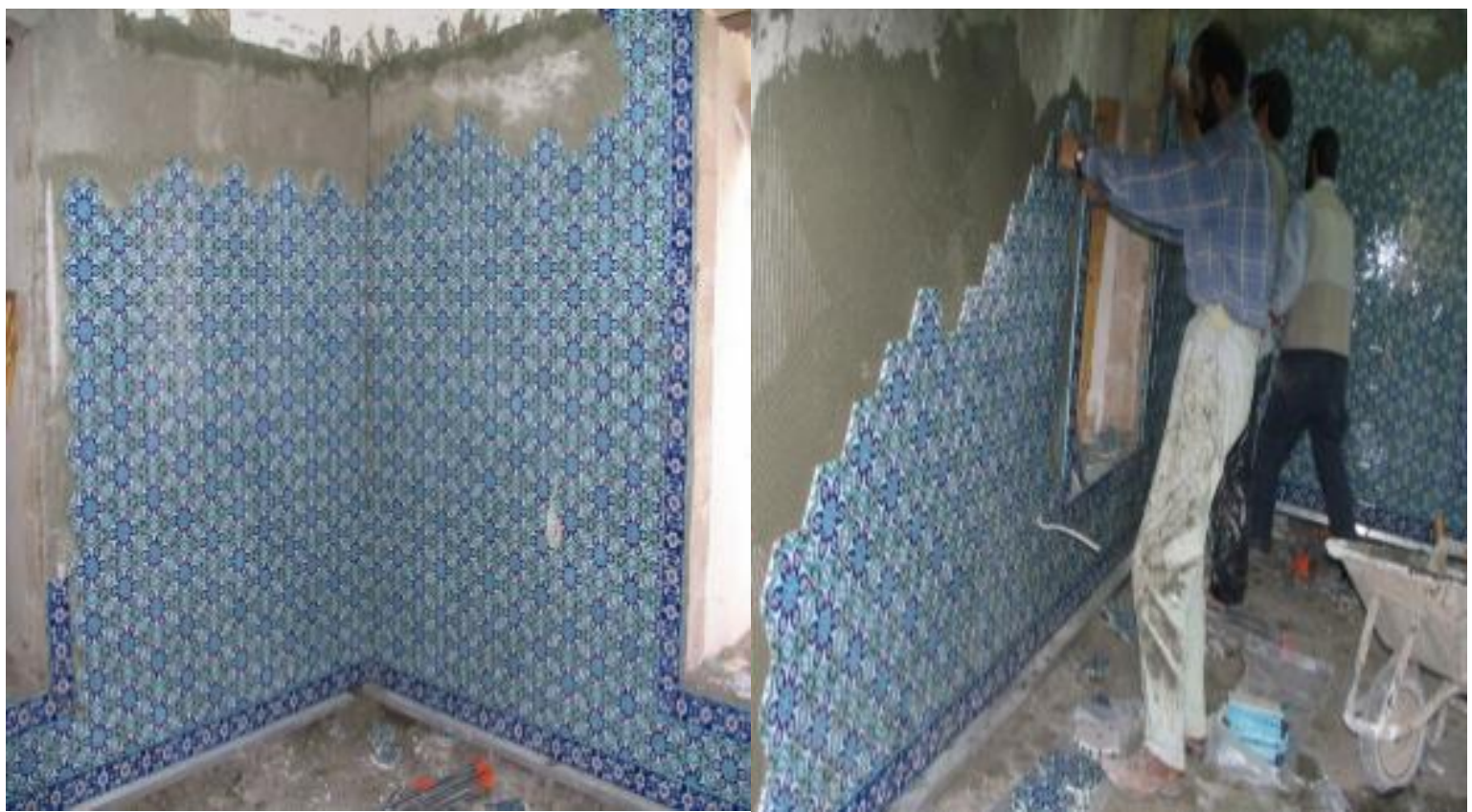

Şekil 53,54. Hüsrev Paşa Camii Çini Kaplama Uygulama Görünüşleri (Ş. Öztürk) 
Vakıflar Genel Müdürlüğü’nün talimatları doğrultusunda mihrap yüzeyinde alınan örnek numuneler ilgili laboratuvarlarda analizleri sonucunda yüzeyin orijinalde altın varaklı bir kaplama ile kaplandığı tespit edilmiştir. Bu maksatla mihrap yüzeyi ile giriş kapısı kitabeli bölümü altın varak uygulaması yapılmışıtır (Şekil 55-59). Cami kubbe kasnağı çevresinde düzenli olarak sıralanan mevut uçan destek payandaları daha önceki onarımlarda aslına uygun olmayan formlarda inşa edilmiştir. Belgeler ve onaylı uygulama projesine uygun olarak yuvarlak eğimli olarak yeniden inşa edilmiştir.
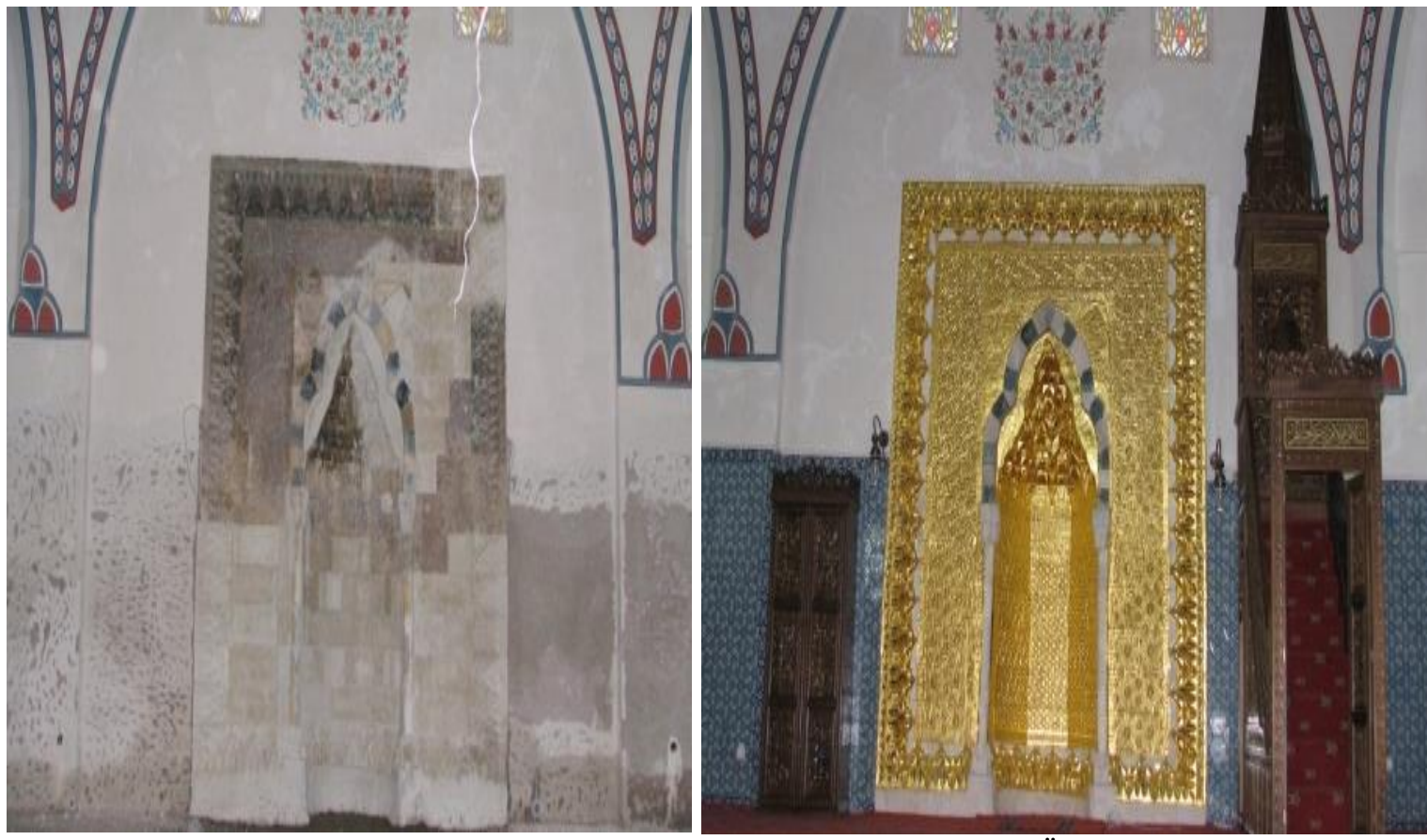

Şekil 55,56. Hüsrev Paşa Camii Mihrap Görünüşleri (Ş. Öztürk)

Cami kubbe bölümünde daha önce koruma amaçlı sıvaların raspası yapılarak horasan kireç harcı ile yapılan koruyucu tabaka üzeri keçe üzeri $1,5 \mathrm{~mm}$. kalınlığında kurşun kaplama ile ana kubbe, son cemaat beş kubbe ve minare külah kısmı kaplaması yapılmıştır. Minare şerefe, korkuluk ve külah bölümlerinin bakım ve onarımları yeniden yapılmıştır (Şekil 60,61).
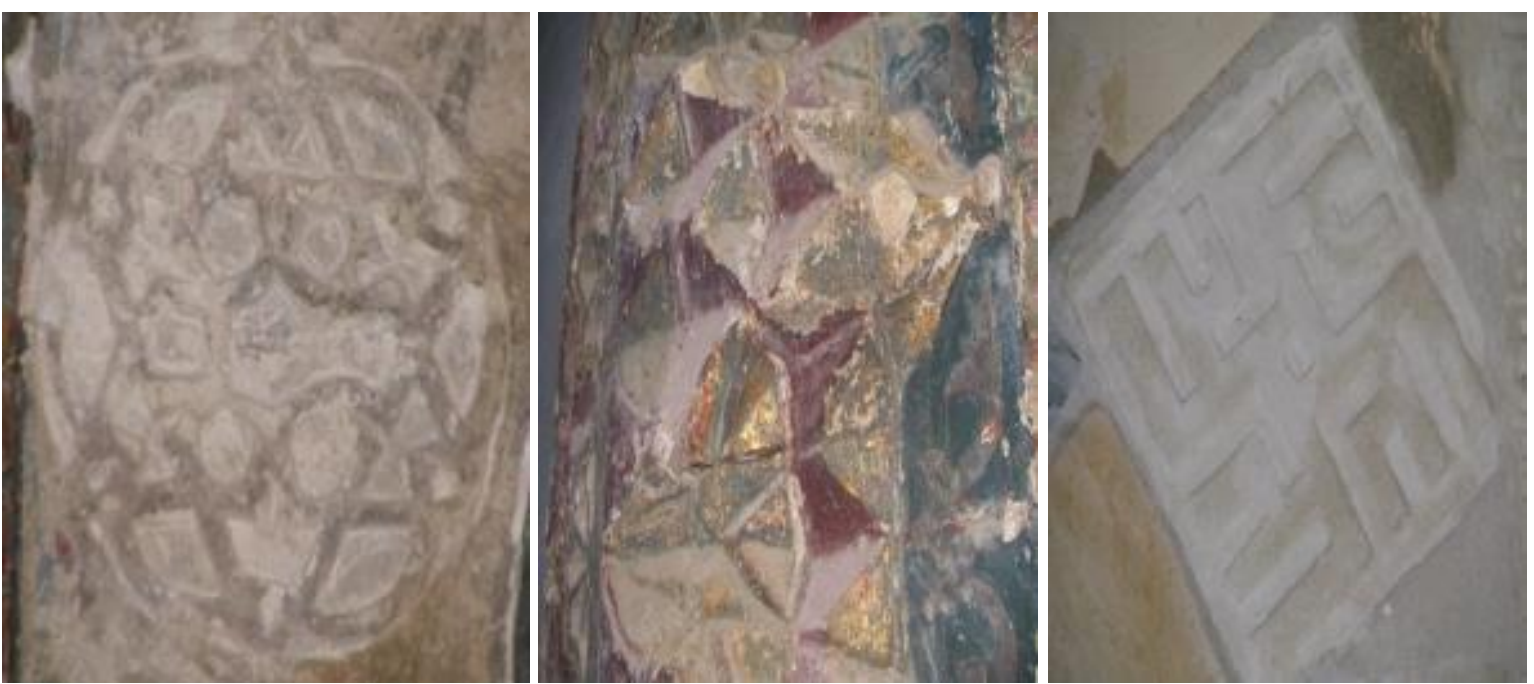

Şekil 57-59. Hüsrev Paşa Camii Mihrap, Mührü Süleyman, Özgün Altın Varak Sülleme ve Küfi Süsleme Görünüşleri (Ş. Öztürk)

Turkish Studies, 15(2) 
Caminin tüm cephelerinin tamamen doğal findık, ceviz kabuğu ve dolomit malzeme ile basınçlı püskürtme yöntemli temizlik yapılmıştır. Cephelerin bakım ve onarımları yeniden yapılarak, bazı bölümlerde yıpranan ve özelliğini yitiren yonu taşlar raspa işlemi sonucunda yeniden onarılmıştır (Şekil 62-64).

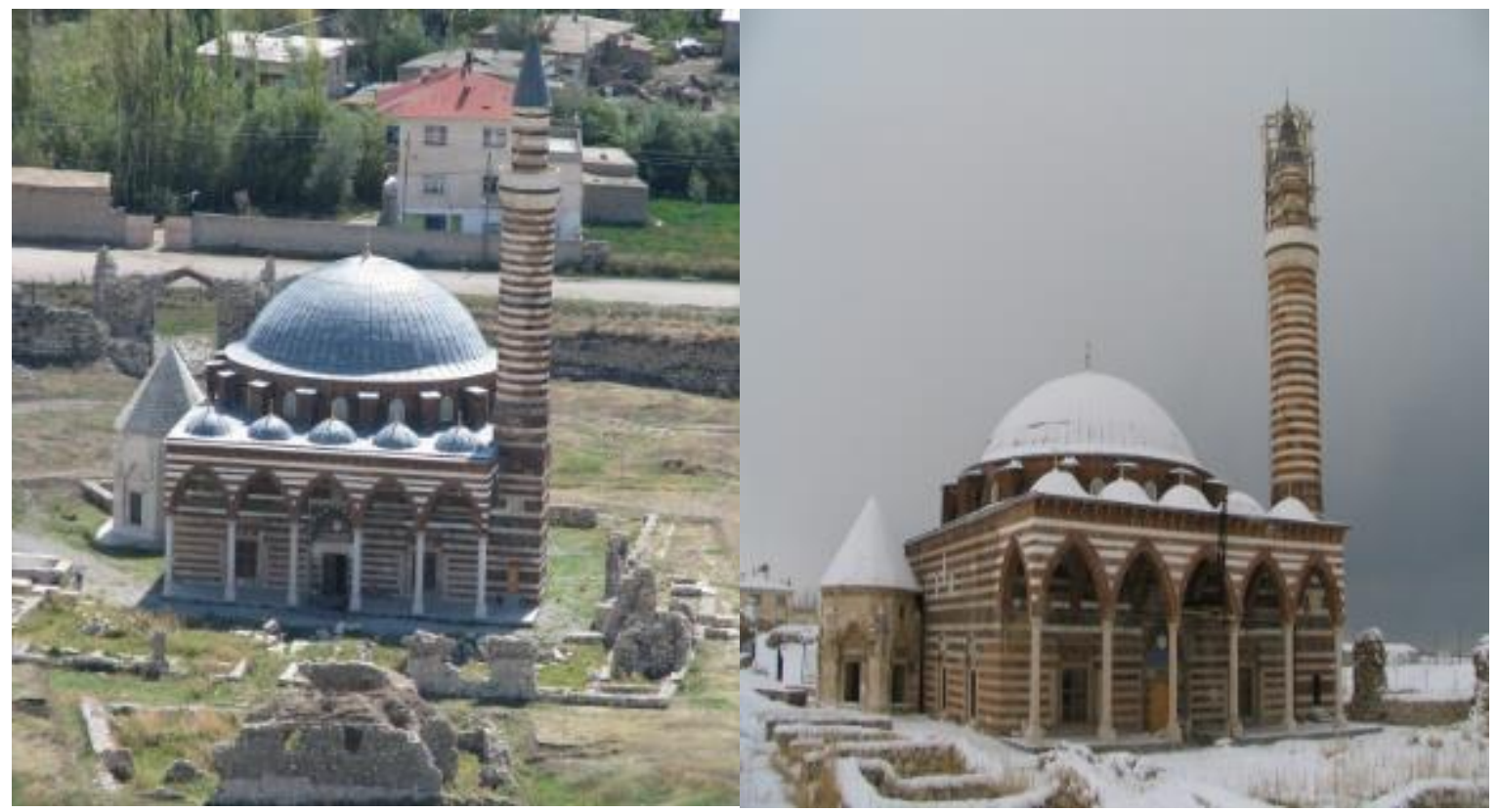

Şekil 60-61. Hüsrev Paşa Camii Kuzey Genel Görünüşleri (Ş. Öztürk)

\section{4-2012-13 Yıllarıarası Bitlis Vakıflar Bölge Müdürlüğü Onarım Çalışmaları;}

Hüsrev Paşa Külliyesi'nin merkezinde yer alan cami, 2008 yılı onarımından sonra ibadete açılmış, 2011 Van Depremi'nin ilk 7,2 büyüklüğündeki olumsuz etkisinden herhangi bir hasar almamıştır. Ancak, 5,6 büyüklüğündeki ikinci depremin olumsuz etkisinden ağır hasar olarak minare ve son cemaat bölümü tamamen yıkılmış, ana kubbe ise orta hasarlı olarak zarar görmüştür (Şekil 65-67).
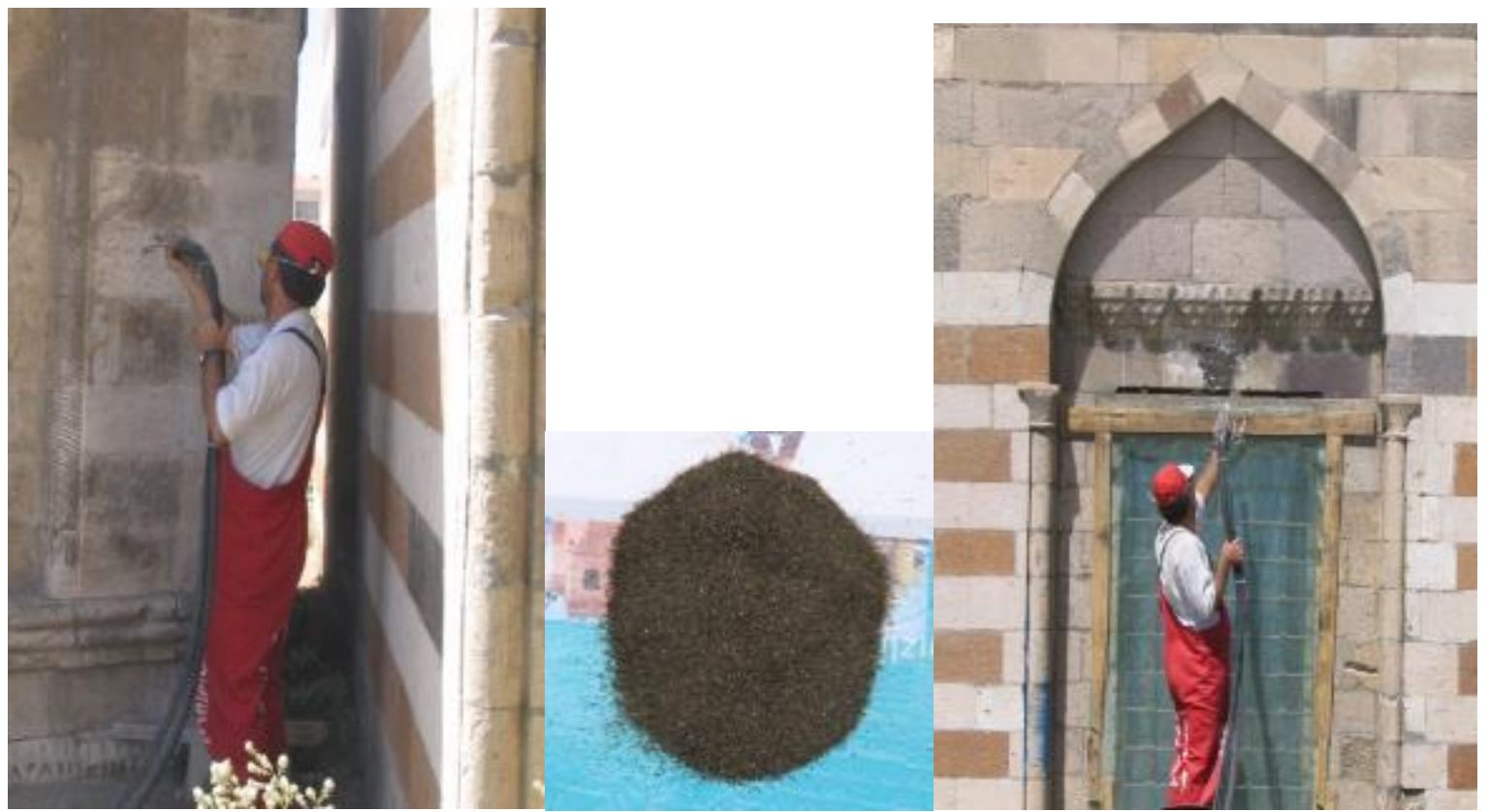

Şekil 62-64. Cami Cephe Doğal Fındık, Ceviz Kabuğu ve Dolomit İle Temizlik Görünüşleri (Ş. Öztürk) 


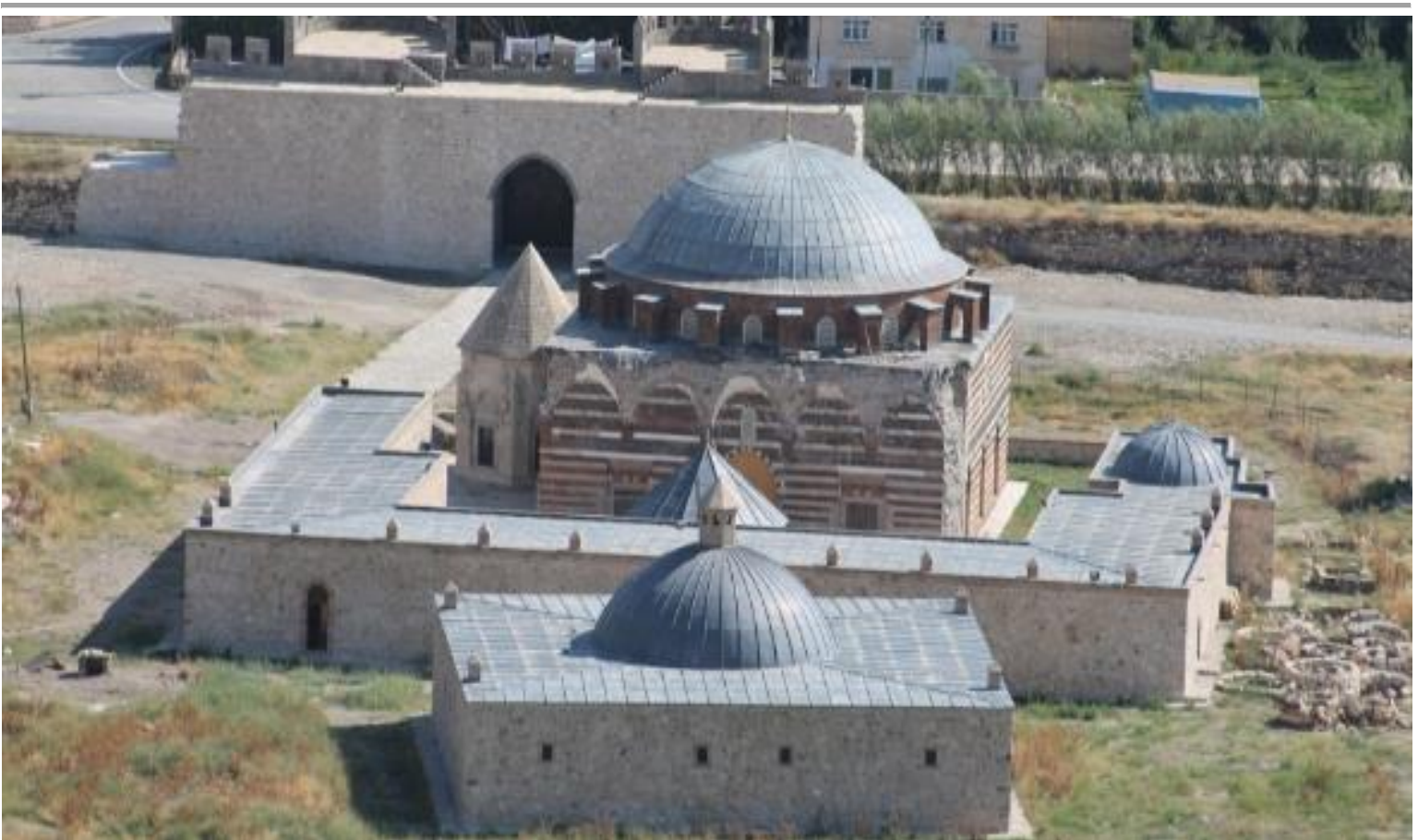

Şekil 65. Hüsrev Paşa Camii 2011 Deprem Sonrası Görünüşü (Ş. Öztürk)

Bitlis Vakıflar Bölge Müdürlüğ̈̈ ve Van Valiliği’nin girişimleri ile deprem sonrası onarım çalışmaları hemen başlatılmışıı. Bu kapsamda mimari projeler Dr. Mimar ve Sanat Tarihçisi Şahabettin ÖZTÜRK tarafından hazırlanmıştır. Caminin statik ve yapısal analiz çalışmaları ise Trabzon Karadeniz Teknik Üniversitesi Mühendislik Fakültesi İnşaat Bölümü Öğretim Üyesi Prof. Dr. Alemdar BAYRAKTAR tarafından hazırlanmıştır. Hazırlanan mimari, statik, yapısal analiz ve raporlar Van Kültür Varlıkları Koruma Bölge Müdürlüğü tarafından onaylanmıştır.

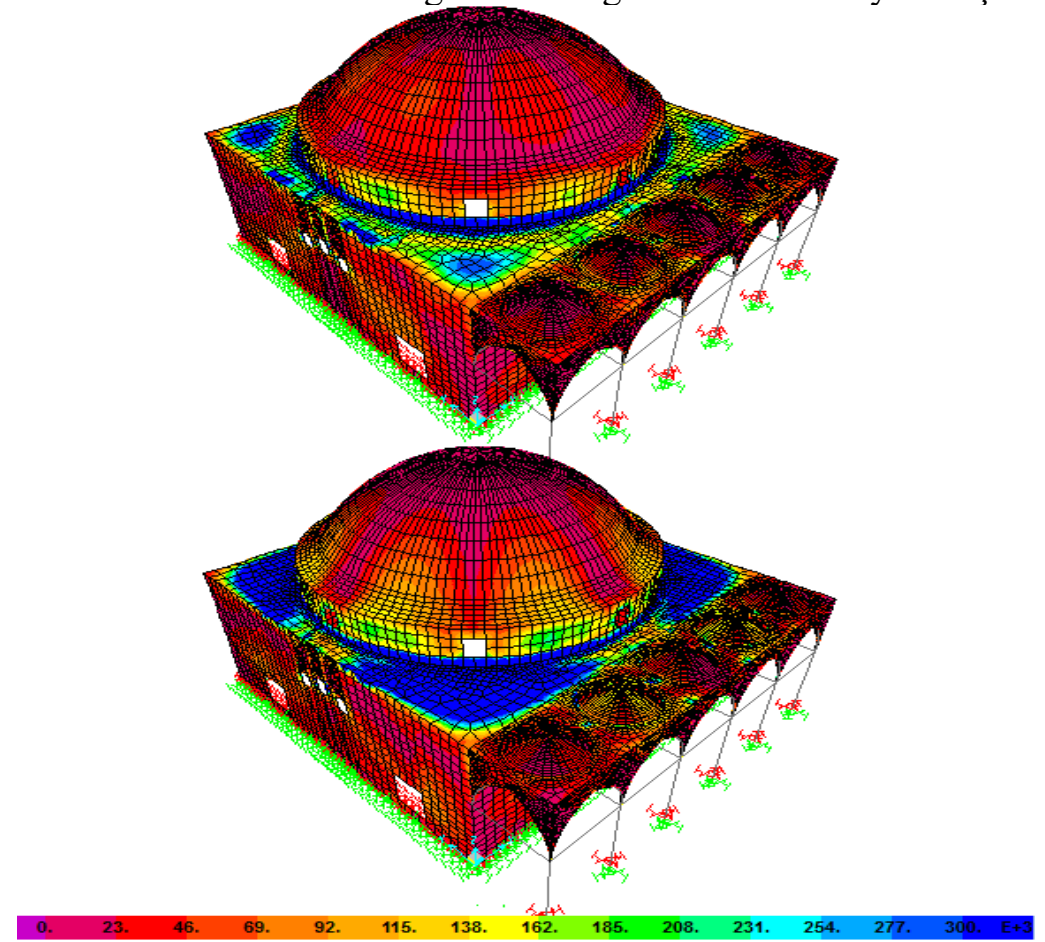

Şekil 66,67. Hüsrev Paşa Camii’nin Deprem Yükleri Altında Kayma Gerilmelerine Ait Kontur Diyagramları (A. Bayraktar) 
Bitlis Vakıflar Bölge Müdürlüğü tarafından 2012 yılında onarım çalışmaları ihalesi yapılmıştır. Yüklenici firma son cemaat bölümü ve kubbe statik sorunlarını hazırlanan ve onaylı mimari ve statik projeler esas alınarak onarım ve sağlamlaştırma çalışmaları yapılarak tamamlanmıştır (Şekil 68-73).

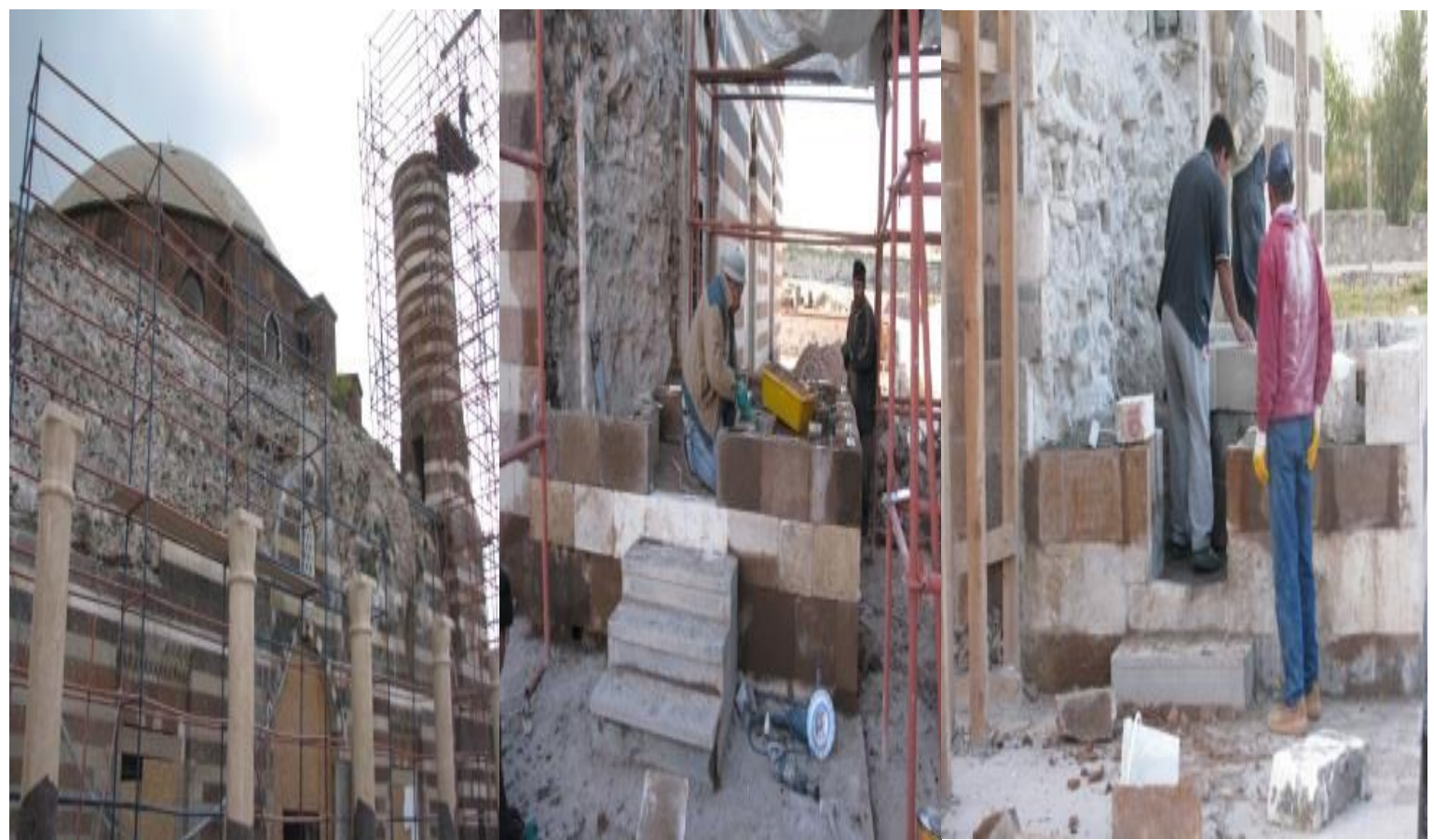

Şekil 68-70. Hüsrev Paşa Camii 2011 Deprem Sonrası Görünüşleri (Ş. Öztürk)

Minare onarım çalışmalarına öncelikle mevcut yapı bölümleri mevcut rölöve projesindeki veriler dikkate alınarak yatayda sayısal, düşeyde alfabetik olarak numaralandırılarak söküm çalışmaları proje müellifi, kontrol elemanları denetiminde titizlikle zeminde belirlenen yerlerde her sıra ayrı ayrı istiflenerek görsel ve video olarak kayıt altına alınmıştır.

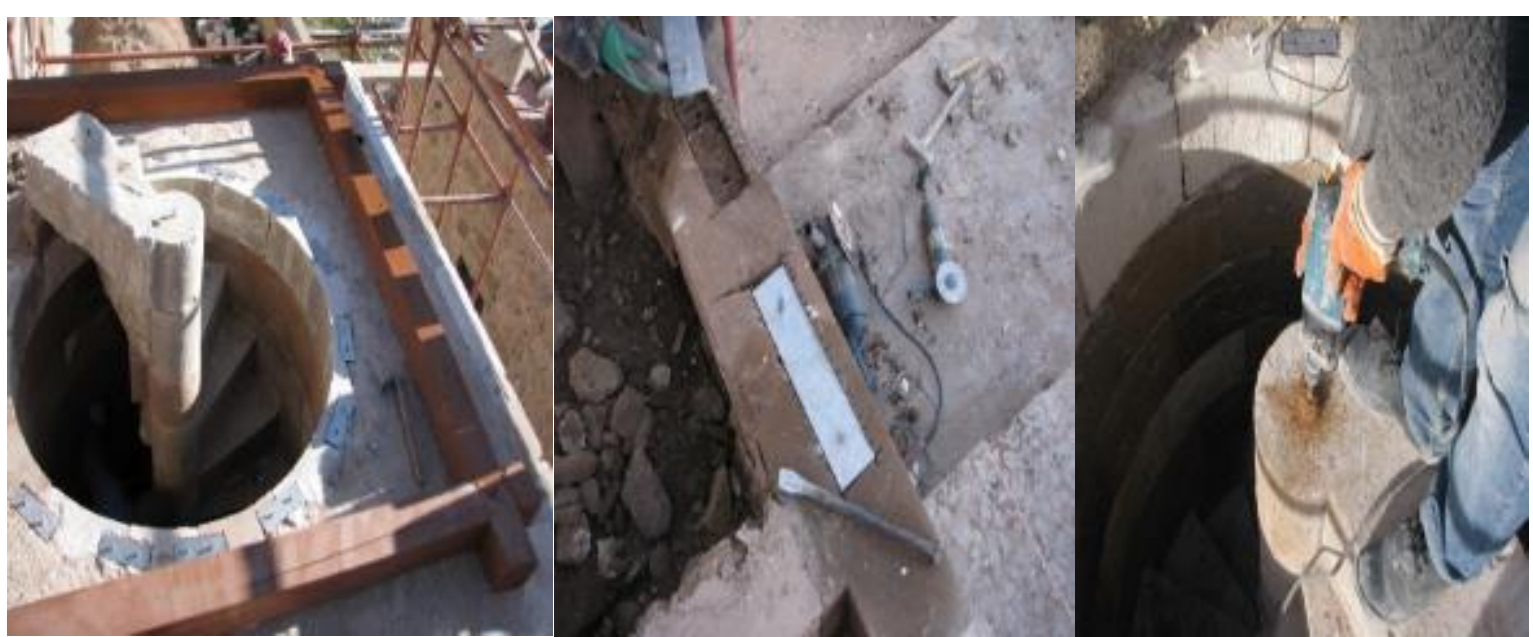

Şekil 71-73. Hüsrev Paşa Camii Minare İnşa Görünüşleri (Ş. Öztürk)

Minareyi yenide kurma çalışması zemin kaideden itibaren petek bölümüne kadar paslanmaz çelik lama ve bulunlar yardımıyla her taş kurşun bağlantılı olarak desteklenerek tamamlanmıştır. Deprem esnasında ve söküm çalışmalarında oldukça tahrip olan kullanılmaz yonu taşların yerine aynı laboratuvar sonuçlarına uygun kalker taşı kullanılmıştır (Şekil 74-85). 

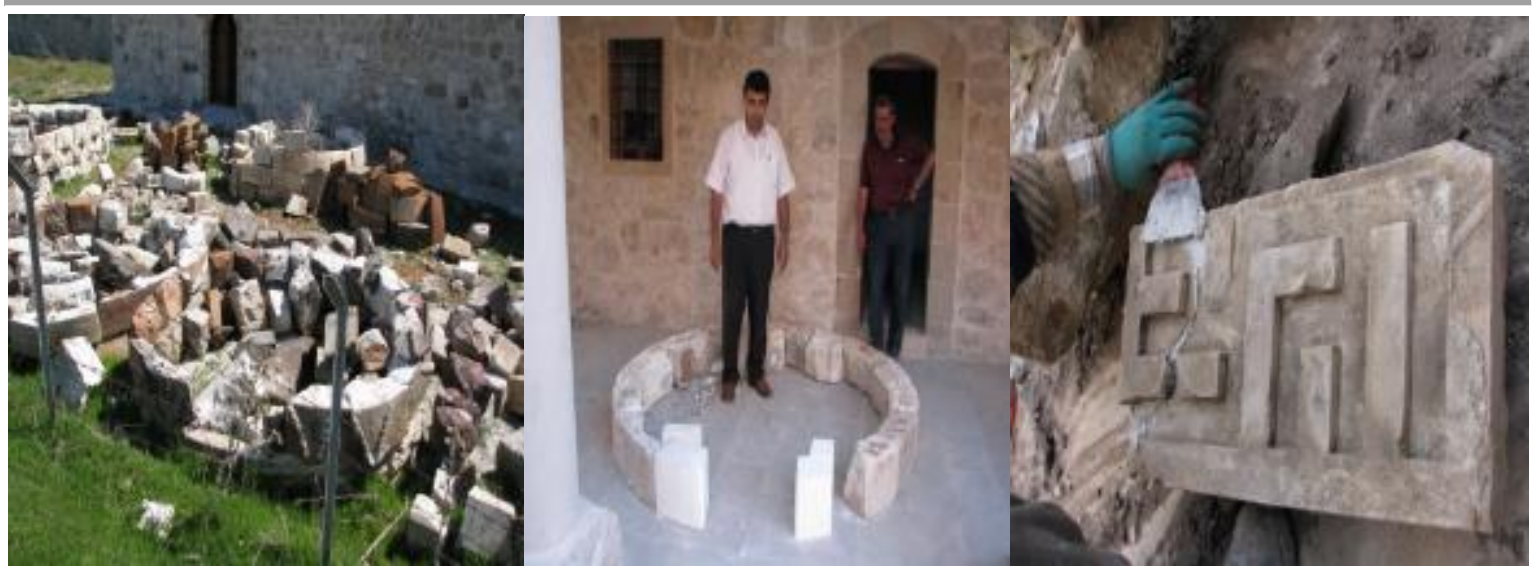

Şekil 74-76. Hüsrev Paşa Camii Minare İnşa Görünüşleri (Ş. Öztürk)

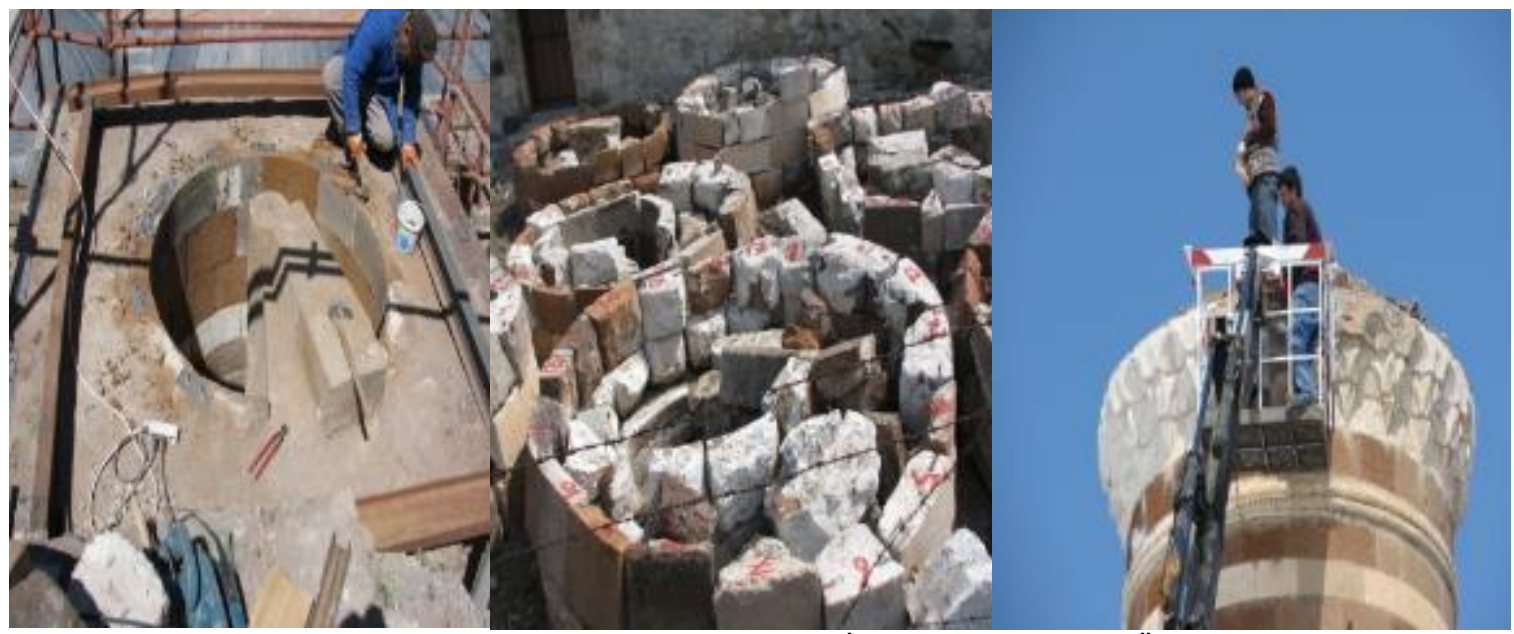

Şekil 77-79. Hüsrev Paşa Camii Minare İnşa Görünüşleri (Ş. Öztürk)

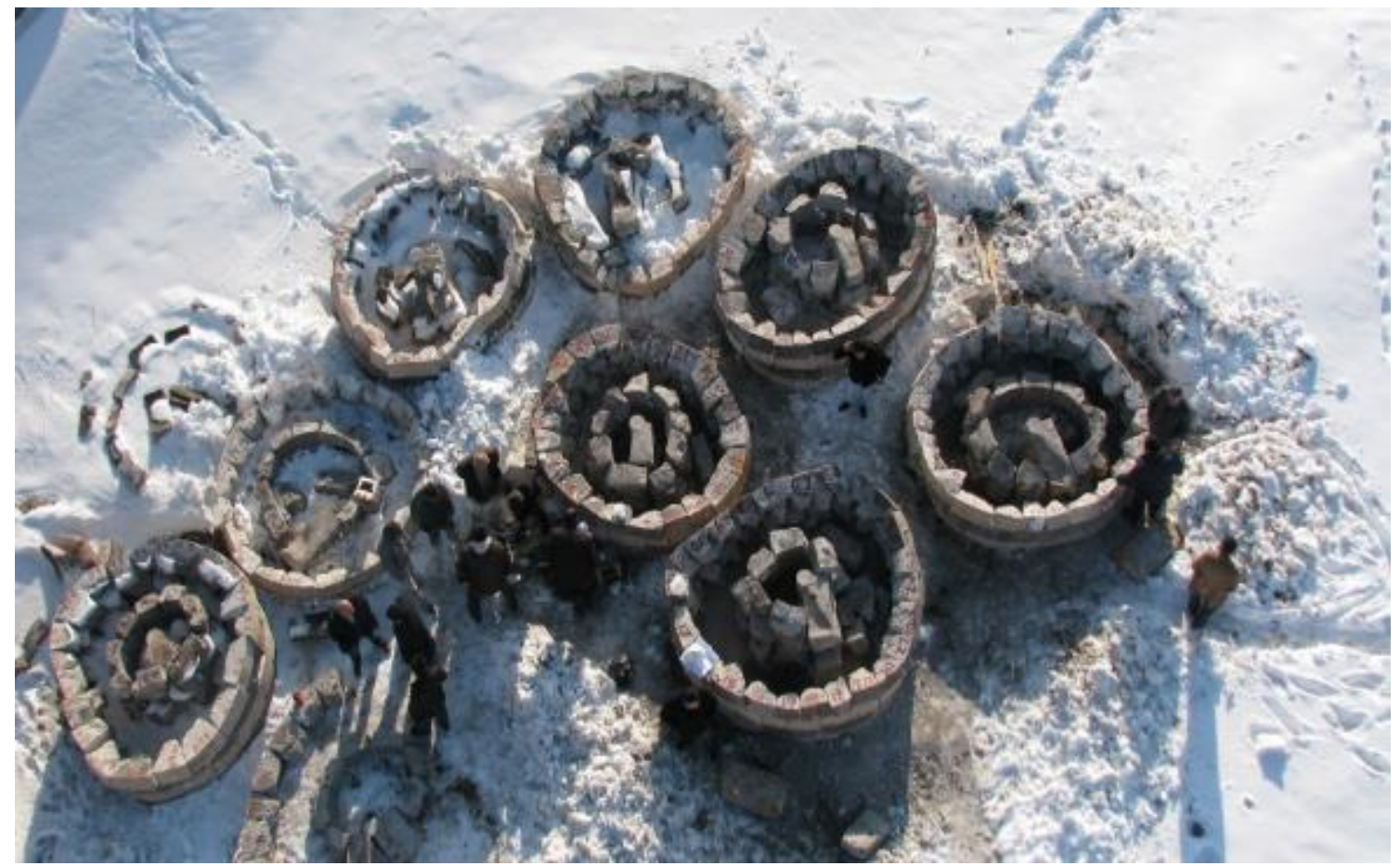

Şekil 80. Hüsrev Paşa Camii Minare İnşa Görünüşü (Ş. Öztürk)

Turkish Studies, 15(2) 

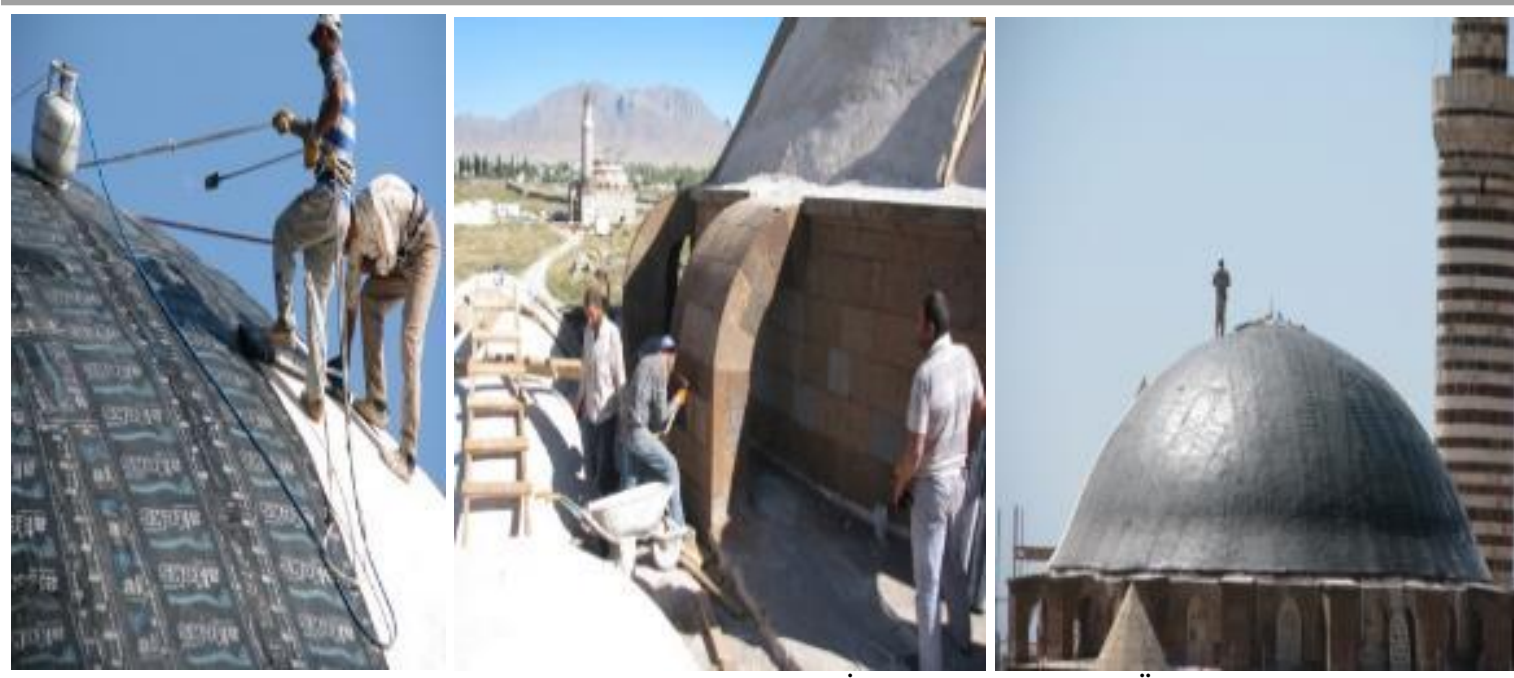

Şekil 81-83. Hüsrev Paşa Camii Kubbe İnşa Görünüşleri (Ş. Öztürk)

Yeni kullanılan yonu taşı miktarı toplam taş miktarının yaklaşık \% 30'una dek gelmektedir. Minare, son cemaat bölümü ve kubbe kasnak onarımlarında horasan kireç harcı ile hidrolik kireç karcı kullanılmıştır. Aslına uygun olarak yapılan onarım çalışmalarından sonra 2013 yılında ibadete açılarak yöre halkı tarafından kullanılmaktadır.

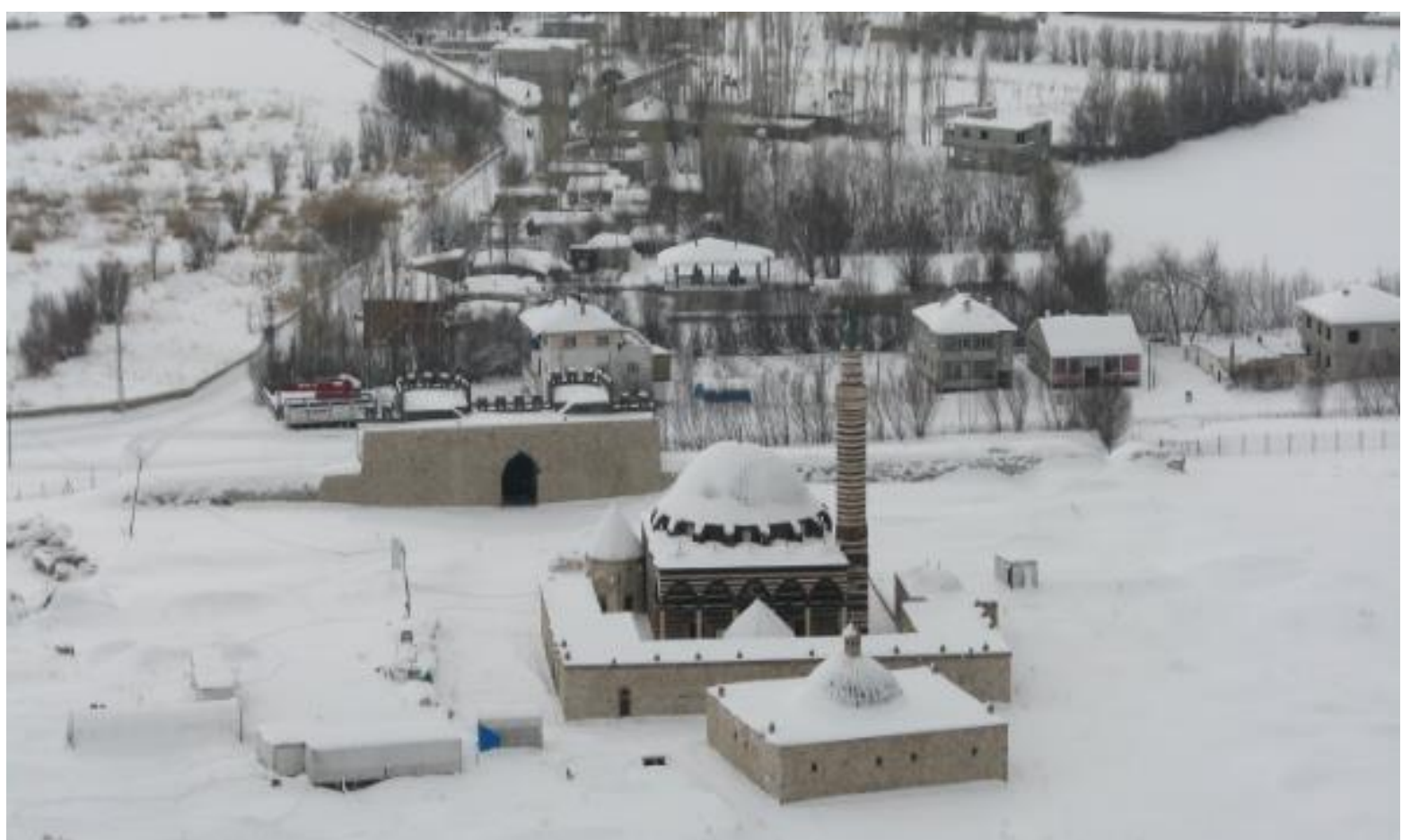

Şekil 84. Hüsrev Paşa Külliyesi Onarım Sonrası Genel Görünüşü (Ş. Öztürk)

\section{Sonuc}

Eski Van Şehri ve Kalesi konum ve stratejik yapısından dolayı, eski çağlardan günümüze kadar birçok uygarlık tarafından kullanılmıştır. Her uygarlık dini, askeri ve sivil mimarlık eserleri ile kadim olan şehri adeta mimari yapılar ile donatmıştır. Kuşkusuz bu önemli kente hayat veren dini mimari yapılar içerisinde Mimar Sinan'nın eseri olan, Hüsrev Paşa Külliyesi’nin önemli bir yer vardır. Osmanlı coğrafyasının en doğusunda eski Van kentinin merkezinde yer alan Hüsrev Paşa Külliyesi, Eski Van Şehri’ndeki önemli dini mimari yapılarından biridir. 


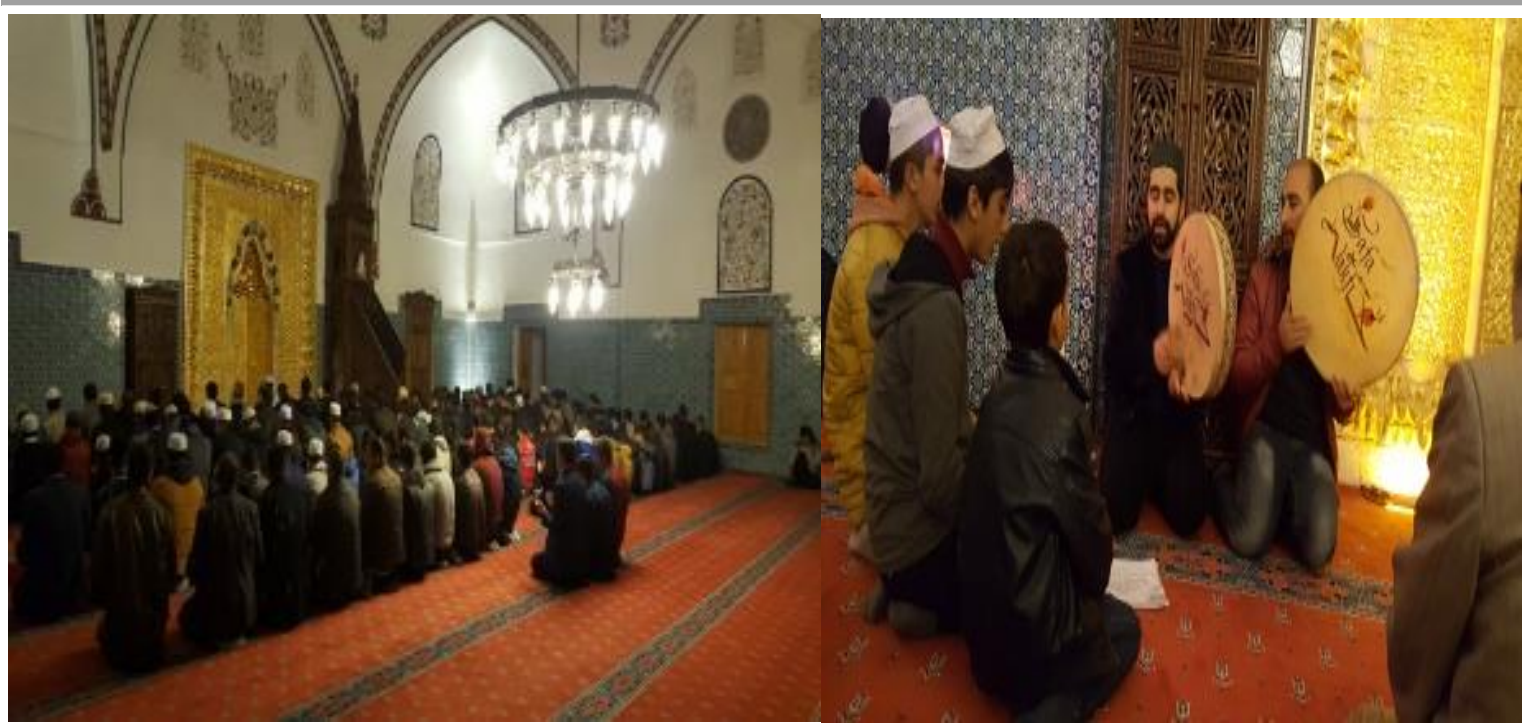

Şekil 85,86. Hüsrev Paşa Camii İç Mekan İbadet ve Dini İlahi Görünüşü (Ş. Öztürk)

Temizlik, proje ve onarım çalışmaları bilimsel disiplin içerisinde yapılan ve günümüzde yöre halkı tarafından aktif olarak kullanılan yapılardan biri Hüsrev Paşa Külliyesi'dir. Onarım sonrası külliyenin önemi gereği Cuma ve önemli diğer dini günlerde bir çok insan tarafından ziyaret ya da ibadet amaçlı olarak kullanılmaktadır. Külliyenin tamamlayıcı mekanlarından olan, cami, imaret, türbe, avlu, şadırvan ve medresenin onarımları yapılarak yöre halkının hizmetine sunulmuştur (Şekil 84-88).

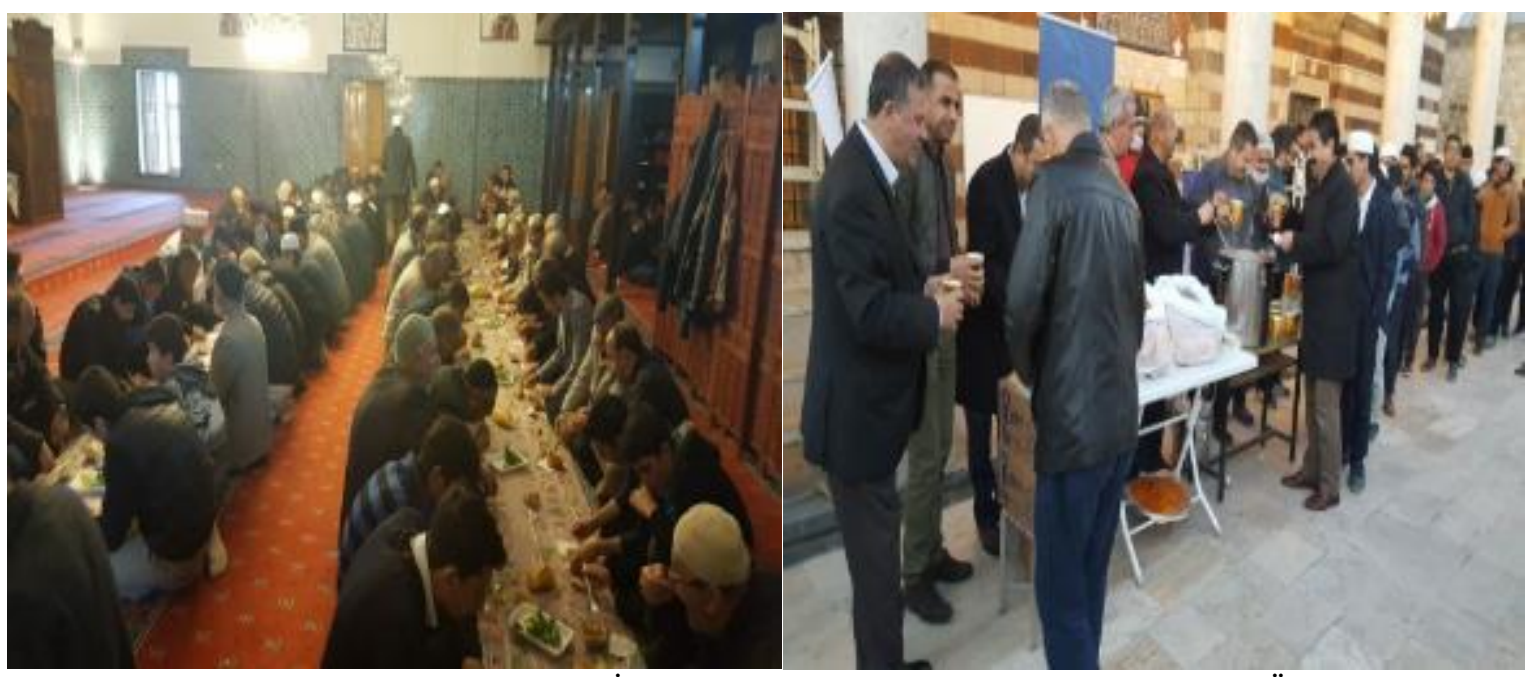

Şekil 87,88. Hüsrev Paşa Camii İ ç -Dış Mekan Sosyal Faaliyet Görünüşleri (Ş. Öztürk)

Külliyenin diğer tamlayıcı unsurlarından han, çifte hamam ve sibyan mektebi gibi mimari yapıların, bilimsel kazı ve uygulama projeleri hazırlanarak ilgili kurul tarafindan projeleri onaylanmıştır. Projelerin uygulaması önümüzdeki günlerde Bitlis Vakıflar Bölge Müdürlüğü tarafından yapılacak çalışmalar ile külliyenin tüm birimleri ile tamamlanacaktır.

Yakın dönemlerde kültürel, turizm amaçlı proje ve uygulamalar sonucunda, Eski Van kentte sosyal ve kültürel etkinliklerde önemli artış olmuştur. Klasik Osmanlı dönemi cami tipinin temsilcisi biri olan Van Hüsrev Paşa Camii, tek kubbeli ve külliyenin tamamlayıcı unsuru olarak inşa edilmiştir. Osmanlı klasik dönemi Van Beylerbeyi olan Hüsrev Paşa ile Mimar Sinan'ın eseri olan külliye yapısının işlevselliği 1915-2009 yılları arasında kesintiye uğramasına rağmen günümüzde Osmanlı devletinin en doğudaki bir tapusu olarak ayakta durmaktadır (Şekil 85-89). 


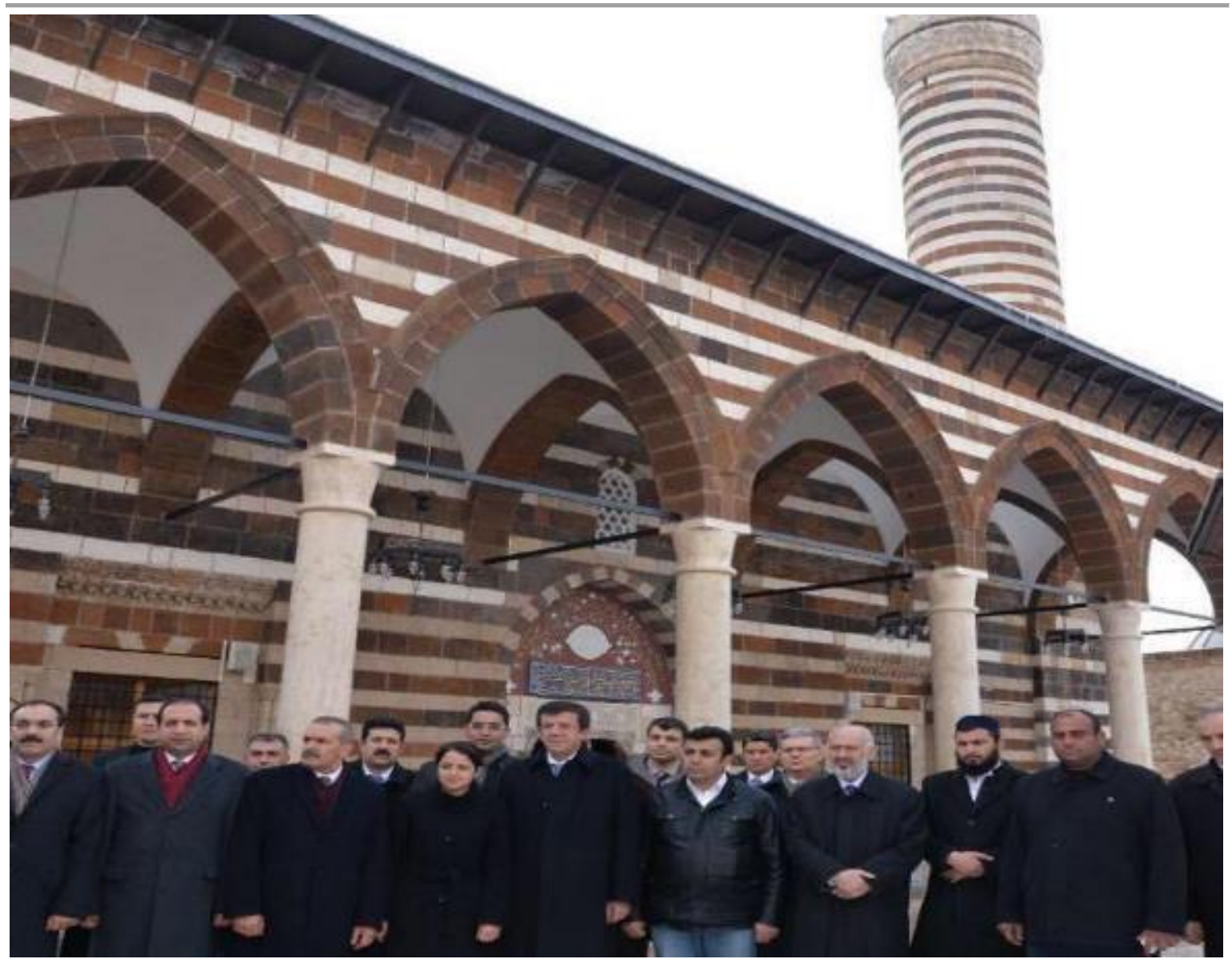

Şekil 89. Hüsev Paşa Camii Açılış Töreni Görünüşü (Ş. Öztürk)

\section{Kaynakça}

Ağaoğlu, S. (2007). Van Şehir Dokusu ve Tarihi Eserlerinin Tahrip Edilmesinde Ermenilerin Rolü. Atatürk Üniversitesi, Türkiyat Araştırmaları Enstitüsü Dergisi, (35), 328-330.

Ağaoğlu, S. (2003). Van Merkez Sancağındaki Vakflar XVI.-XVII. Yüzylllar-Sosyal Hayata ve Ĕgitime Katkıları, (Yayımlanmamış doktora tezi). Selçuk Üniversitesi Sosyal Bilimler Enstitüsü, Konya.

Belli, V.E. (2009). Van Hüsrev Pașa Camisi’ndeki Taș, Çini ve Kalem İși Süslemelerin Bozulma Nedenleri, (Yayımlanmamıs yüksek tezi). Kadir Has Üniversitesi Fen Bilimler Enstitüsü, İstanbul.

Boran, A. (1994). Van Gölü Çevresindeki Tek Kubbeli Camilerin Türk Sanatındaki Yeri. (Yayımlanmamış yüksek lisans tezi). Yüzüncü Y1l Üniversitesi Sosyal Bilimler Enstitüsü, Van.

Çelebi, E. (1976). Seyahatname, C. 3-4, İstanbul: Üçdal Neşriyat.

Demiroğlu, F. (1958). Hüsrev Paşa Cami, İki Nisan Gazetesi, 20.3.1958, Van, s. 2.

Eyice, S. (1999). Türkiye Diyanet Vakfi İslam Ansiklopedisi içinde (Cilt 19, 49-51. ss.). İstanbul.

Günel, F. M. (1993). Eski Van Kent Dokusu Üzerine Bir Deneme. (Yayımlanmamış yüksek lisans tezi). Yüzüncü Y1l Üniversitesi Sosyal Bilimler Enstitüsü, Van. 
Kuran, A. (1986) Mimar Sinan, İstanbul: Hürriyet Vakıf Yayınları.

Öztürk, Ş. (1996). Van-Ahlat ve Adilcevaz Tarihi Camileri Rölöve Proje Çalışması. (Yayımlanmamış yüksek lisans tezi). Yüzüncü Yı1 Üniversitesi Sosyal Bilimler Enstitüsü, Van.

Öztürk, Ş. (1999). Sinaniye, Abbas Ağa ve Horhor Camileri. Dünyada Van Dergisi, (18), 14-19.

Öztürk, Ș. ve Mızrak, A. (2001). Eski Van Şehir Surları, Mimarlı İ̧̧ Mimarlık ve Görsel Sanatlar Dergisi, 102, 32-34.

Öztürk, Ş. (2004). Mimarlık ve Kent, Turkuaz: Denizin Coğrafyasında Van Eski Van: Şehri, TMMOB Mimarlık Dergisi, 317, 52-54.

Öztürk, Ş. (2008). Van Hüsrev Paşa Külliyesi (Cami, Medrese, Imaret, Türbe, Avlu) Rölöve, Restitüsyon, Restorasyon ve Rekonstrüksiyon Projeleri Koruma Raporu.

Öztürk, Ş. (2019). Eski Van Şehri Kızıl Cami Rölöve, Restitüsyon ve Restorasyon Proje Uygulaması Hakkında Bir Araştırma. The Journal Of Internatıonal Socıal Research, 12 (65), 352-369.

Öztürk, Ş. (2018). Eski Van Şehri Horhor Cami Kazı ve Restorasyonu, Dicle Üniversitesi, 1. Uluslararası Mimarlık Sempozyumu, (1753-1772 ss.). Diyarbakır.

Öztürk, Ş. (2012). Van Kalesi'nde Bir Dini Mimarlık Örneği: Süleyman Han Camii Restorasyon Çalışmaları. Atatürk Güzel Sanatlar Enstitüsü Dergisi, (28), 39-54.

Sönmez, Z. (1988). Mimar Sinan ile İlgili Tarihi Yazmalar-Belgeler. İstanbul: Mimar Sinan Üniversitesi Yayınları.

Uluçam, A. (2000). Ortaçağ ve Sonrasında Van Gölü Çevresi Mimarlı̆̆ı I Van. Ankara: Türk Tarih Kurumu Basımevi.

Uluçam, A. (2002). Van ve Çevresindeki Osmanlı Medreseleri İle Eğitim Öğretimdeki Yerleri, XII. Türk Tarih Kongresi, III. Türk Tarih Kurumu. (5,6 ss.). Ankara.

Uluçam, A. ve Kavakl1, E. (2010). Eski Van Hüsrev Paşa Külliyesi Kazıs1-1999. IV. Ortaçağ ve Türk Dönemi Kazıları ve Araştırmalar Sempozyumu Bildirileri (24-27 Nisan 2000 Van). (11-16 ss.). Van.

Van Vilayet Salnamesi, 1315 (Van İl Yıllı̆̆ı-1899), Van, 1995.

Tarhan, M. T. (1985). Van Kalesi’nin ve Eski Van Șehri’nin Tarihi-Milli Park Projesi Üzerinde Ön Çalışmalar (I): Anıtlar”, Eski Eserler ve Müzeler Genel Müdürlügü,. III. Araştırma Sonuçları Toplantısı, (Ankara 20-24 Mayıs 1985 Ankara). (297-355 ss.). Ankara. 